Published in final edited form as:

Mol Genet Metab. 2014 August ; 112(4): 317-338. doi:10.1016/j.ymgme.2014.04.007.

\title{
Pleiotropic genes for metabolic syndrome and inflammation
}

\author{
A full list of authors and affiliations appears at the end of the article.
}

\section{Abstract}

Metabolic syndrome (MetS) has become a health and financial burden worldwide. The MetS definition captures clustering of risk factors that predict higher risk for diabetes mellitus and cardiovascular disease. Our study hypothesis is that additional to genes influencing individual MetS risk factors, genetic variants exist that influence MetS and inflammatory markers forming a predisposing MetS genetic network. To test this hypothesis a staged approach was undertaken. (a) We analyzed 17 metabolic and inflammatory traits in more than 85,500 participants from 14 large epidemiological studies within the Cross Consortia Pleiotropy Group. Individuals classified with MetS (NCEP definition), versus those without, showed on average significantly different levels for most inflammatory markers studied. (b) Paired average correlations between 8 metabolic traits and 9 inflammatory markers from the same studies as above, estimated with two methods, and factor analyses on large simulated data, helped in identifying 8 combinations of traits for followup in meta-analyses, out of 130,305 possible combinations between metabolic traits and inflammatory markers studied. (c) We performed correlated meta-analyses for 8 metabolic traits and 6 inflammatory markers by using existing GWAS published genetic summary results, with about 2.5 million SNPs from twelve predominantly largest GWAS consortia. These analyses yielded 130 unique SNPs/genes with pleiotropic associations (a SNP/gene associating at least one

(C) 2014 Elsevier Inc. All rights reserved.

${ }^{\dagger}$ Correspondence to: Aldi T. Kraja, DSc, PhD, Division of Statistical Genomics, Department of Genetics and Center for Genome Sciences and Systems Biology, Washington University School of Medicine, St. Louis, MO 63108, phone: 314-362-2498, aldi@wustl.edu, James B. Meigs, MD, MPH, General Medicine Division, Massachusetts General Hospital, Boston, MA 02114, 617-724-3203, jmeigs@ partners.org, Ingrid B. Borecki, PhD, Division of Statistical Genomics, Department of Genetics and Center for Genome Sciences and Systems Biology, Washington University School of Medicine, St. Louis, MO 63108, phone: 314-362-3690, iborecki@wustl.edu.

Writing group.

Publisher's Disclaimer: This is a PDF file of an unedited manuscript that has been accepted for publication. As a service to our customers we are providing this early version of the manuscript. The manuscript will undergo copyediting, typesetting, and review of the resulting proof before it is published in its final citable form. Please note that during the production process errors may be discovered which could affect the content, and all legal disclaimers that apply to the journal pertain.

Author contributions

A.T.K., J.B.M., I.B.B conceived the study project; A.T.K., D.I.C, K.E.N., A.P.R., L.R.Y., T.O.K., J.A.S., A.D, J.D., M.G.L, B.Z.A., I.P., J.B.M., and I.B.B. researched data, contributed to discussion and wrote the manuscript; A.D.J., M.F.F, F.T.A., A.Y.C., I.M.N., Z.D., A.M., S.A.P., Y.V.S., M.D.R., A.V., H.L., S.L., L.M., R.R., Y.S., M.A.Z., H.K.I., R.B.S., T.J., M.E.J., T.H., O.P., R.P.S., H.S., A.H., A.G.U., O.H.F., M.A.I., J.B.R., C.R., J.G.W., L.L., S.K.G., M.N., L.J.R., J.S.P., J.C., W.T., W.H.L.K., E.B., A.C.M., P.M.R., D.M.B., J.I.R., S.L.R.K., R.J.F.L, Y.H., M.A.P., R.T., B.F.V., D.V., C.O., and E.J.B. researched data or contributed to discussion and reviewed/edited the manuscript.

Guarantor's statement: Drs. Aldi T. Kraja and Ingrid B. Borecki are the guarantors of this work and, as such, had full access to all results produced for this study and take responsibility for the integrity of the results and of the accuracy of the analyses. Drs. Daniel I. Chasman, Kari E. North, Alexander P. Reiner, Lisa R. Yanek, Tuomas O. Kilpeläinen, Jennifer A. Smith, Abbas Dehghan, Martin G. Larson, and Behrooz Z. Alizadeh are the guarantors of the individual studies, as such, had full access to all results produced by their corresponding study and take responsibility for the integrity of the results and of the accuracy of their results analyses.

Conflict of Interest

All authors have no conflict of interest to declare. 
metabolic trait and one inflammatory marker). Of them twenty-five variants (seven loci newly reported) are proposed as MetS candidates. They map to genes MACF1, KIAA0754, GCKR, GRB14, COBLL1, LOC646736-IRS1, SLC39A8, NELFE, SKIV2L, STK19, TFAP2B, BAZ1B, BCL7B, TBL2, MLXIPL, LPL, TRIB1, ATXN2, HECTD4, PTPN11, ZNF664, PDXDC1, FTO, $M C 4 R$ and TOMM40. Based on large data evidence, we conclude that inflammation is a feature of MetS and several gene variants show pleiotropic genetic associations across phenotypes and might explain a part of MetS correlated genetic architecture. These findings warrant further functional investigation.

\section{INTRODUCTION}

Metabolic syndrome (MetS) is a constellation of medical conditions that include abdominal obesity with visceral fat deposition, atherogenic dyslipidemia (high triglyceride and low high density lipoprotein cholesterol levels), hyperglycemia and/or insulin resistance, and high blood pressure [1]. Due to the rise in obesity rates and poor dietary habits, MetS has become an increasing public health and financial burden [2-7]. MetS is associated with at least five-fold increased risk in developing diabetes mellitus (T2D) and two-fold increased heart disease risk [5]. Recently, it was reported that individuals with acute ischemic stroke and metabolic syndrome have increased inflammation and arterial stiffness [8, 9]. Overall MetS captures a confluence of clinical disorders, assisting front-line practitioners in identifying cardiovascular and metabolic risk factors requiring simultaneous clinical attention $[1,10]$.

There are differing ideas regarding the genetic etiology and cardiovascular sequelae of MetS, including whether the MetS components are independent in origin or share common determinants. At the phenotypic level, the increased cardiovascular disease (CVD) risk associated with MetS appears to be no greater than the sum of its single traits' risk [11, 12].

Individuals with MetS, often exhibit a pro-inflammatory state, with increased levels of Creactive protein, white blood cell count, coagulation factors VII, VIII and fibrinogen, von Willebrand factor, plasminogen activator inhibitor 1 , soluble vascular adhesion molecules such as intercellular adhesion molecule 1 (ICAM-1), P-selectin as well as decreased levels of adiponectin [13-17]. It has been suggested that modified cytokine expression associating a greater volume of adipose tissue may be a mechanism for the low grade inflammation accompanying dysregulated lipid and glucose metabolism, as well as blood pressure [13, 18, 19]. Henneman et al. [12] recommended the genetic dissection of MetS be approached by studying individual components, because of their high heritability. Currently, it remains unclear whether genetic variants identified for individual metabolic traits [20-24] and inflammatory markers [25-29], have pleiotropic effects, thereby influencing the correlated architecture of these traits. Dallmeier et al. [30] suggested that the relationship between MetS and a number of inflammatory markers is largely accounted for by the individual MetS components, and MetS as a construct generally is no more than the sum of its parts with respect to inflammation. We propose that in addition to genes influencing individual MetS risk factors, there are genetic variants that influence MetS risk factors and inflammatory markers, forming a pleiotropic intertwined genetic network. As part of the 
"Pleiotropy among Metabolic traits and Inflammatory-prothrombotic markers" working group, a sub-group of the Cross Consortia Pleiotropy Group, we aimed to: (a) evaluate epidemiological associations between MetS and inflammatory markers; (b) assess correlations among metabolic traits and inflammatory markers for identifying combinations to explore for potentially genetic pleiotropic associations and pathways; (c) utilize these newly identified trait-combinations to perform correlated meta-analyses using previously published GWAS meta-results from large consortia for the individual traits, with the overall goal of detecting MetS candidates with potential pleiotropic effects across metabolic traits and inflammatory markers.

\section{MATERIALS AND METHODS}

\section{A Brief Summary of Implemented Methods}

The international collaboration of Cross Consortia Pleiotropy Group (XC-Pleiotropy) was founded in the early 2011 for studying pleiotropy by using published GWAS results. The PMI-WG is a collaborative group within the XC-Pleiotropy (Supplement 1). For implementing the first two aims (see Introduction), 17 metabolic traits and inflammatory markers are studied (Methods.1), from 14 large-scale cohort studies (dependent on cohortspecific assay availability, Table 1.a and Supplement 2). Together these data represent more than 85,500 individuals (Supplemental Table 1). Laboratory methods for obtaining these traits are described in Supplement 2. Traits adjustments for medication use and other covariates are provided in Methods.2. Methods of estimating correlations with simulations and Fisher's Z-transformation are provided in Methods.3, and factor analysis in Methods.4. Each study was approved by its local ethics board and each participant provided written, informed consent.

For implementing the third aim (see Introduction), we utilized published full results from mainly GWAS meta-analyses consortia (Table 1.b). We performed meta-analyses taking correlation among results into consideration [31,32] (Methods.5) for identifying pleiotropic variants for metabolic traits and inflammatory markers. In this paper, a leading SNP and its mapped gene are considered pleiotropic when the SNP associates with at least a metabolic trait and an inflammatory marker and passes the meta-analysis threshold. In this framework, our study includes published results for body mass index (BMI) [23], waist circumference (WAIST) [33], high density lipoprotein cholesterol (HDLC) and triglycerides (TG) [24], fasting glucose (GLUC) and fasting insulin (INS) [20], systolic and diastolic blood pressure (SBP, DBP) [22]. In addition, our meta-analyses included inflammatory markers, C-reactive protein (CRP) [25], plasminogen activator inhibitor 1 (PAI-1) [26], white blood cell counts (WBCC) [27], adiponectin (ADIP) [34], intercellular adhesion molecule 1 (ICAM-1) [28], and interleukin 6 (IL-6) [35]. Because interleukin 10 (IL-10) was not significantly correlated with other traits, and fibrinogen (FIB) and tumor necrosis factor alpha (TNFA) metaanalyses GWAS results were not available, (although analyzed when studying correlations), these three traits are not present in our final meta-analyses. The reported allele frequencies were based on GIANT BMI. When the SNP was not studied in GIANT consortium BMI, then allele frequencies from MAGIC consortium GLUC were used. We also used bioinformatics approaches for appraising pleiotropy (Methods.6). 


\section{Traits studied}

To evaluate the associations between inflammatory markers and MetS risk factors, seventeen traits were studied. Metabolic traits included were BMI $\left(\mathrm{kg} / \mathrm{m}^{2}\right)$ and WAIST (in $\mathrm{cm}$ ) representing domains of adiposity/obesity, for lipids HDLC ( $\mathrm{mg} / \mathrm{dL}$ ) and fasting (at least 8 hours) TG (mg/dL), for glucose metabolism and insulin, fasting INS (mU/L) and fasting GLUC ( $\mathrm{mg} / \mathrm{dL})$, for blood pressure SBP and DBP $(\mathrm{mm} \mathrm{Hg}$, as average of all three, or the 2-nd and 3-rd seating blood pressure measures). We use the term "inflammatory markers" for brevity when referring to the inflammatory - prothrombotic markers. Inflammatory markers studied were fibrinogen (FIB) $(\mathrm{mg} / \mathrm{dL})$ and PAI-1 (IU/mL) representing prothrombotic markers, and CRP (mg/L), tumor necrosis factor alpha (TNFalpha) (pg/mL), ICAM-1 (ng/mL), IL-6 (pg/mL), interleukin 10 (IL-10) (pg/mL), WBCC $(10 \mathrm{e} 9 / \mathrm{L})$ and ADIP $(\mu \mathrm{g} / \mathrm{mL})$ representing markers of immune or inflammatory response. The studies had a variable number of traits, dependent on the assays performed (Supplement 2). In the study of correlations, because we could not pool individual data from cohorts, we sought to find the average correlation among all traits for 14 cohorts through two methods, using simulations and using Fisher's Z-transformation. The MetS definition, data analyses methods, adjustments for medications use (for blood pressure and lipids medications) and covariates were similar for all contributing cohorts and described in Methods.2.

\section{MetS definition, variables' adjustments for medications and other covariates}

A participant was classified with MetS when thresholds were passed for three or more out of five traits of the National Cholesterol Education Program (NCEP) improved threshold [36]: WAIST $2102 \mathrm{~cm}$ for men/WAIST $\geq 88 \mathrm{~cm}$ for women; GLUC $\geq 100 \mathrm{mg} / \mathrm{dL} ; \mathrm{TG} \geq 150 \mathrm{mg} / \mathrm{dL}$; $H D L C<40 \mathrm{mg} / \mathrm{dL}$ for men/HDLC $<50 \mathrm{mg} / \mathrm{dL}$ for women; $S B P \geq 130 \mathrm{mmHg} / \mathrm{DBP} \geq 85$ $m m H g$. The MetS was based on the improved NCEP definition [36] using original traits adjusted for medication use only (in all cohorts, except for WGHS, which did not measure GLUC), representing (B) set of data (see Supplemental Tables 9-22). T2D was defined as following: (GLUC $\geq 126 \mathrm{mg} / \mathrm{dL}$, or using anti-diabetic medications or insulin) and diabetes onset age $\geq 40$ years.

The average blood pressure was adjusted for individuals using antihypertensive medication(s) as follows, $S B P=$ measured $S B P+15 \mathrm{mmHg}$; and $D B P=$ measured $D B P+$ $10 \mathrm{mmHg}$ [37]. For individuals using anti-hyperlipidemic medications, their lipid levels were adjusted respectively as follows, $H D L C=$ measured $H D L C /(1+0.04419)$; and $T G=$ measured $T G /(1-0.17159)$. For lipids, adjusting constants are produced as a summary of Wu et al. work [38] and also from our additional unpublished summary follow-up, which combined together a total of 92 clinical trials (for HMG-CoA reductase inhibitors, Fibric Acid Derivatives, Cholesterol Absorption inhibitor, Nicotinic acid derivatives, Bile sequestrants and Fish oil) including 53,005 participants for HDLC and 53,432 participants for TG. All participating studies set to missing GLUC and INS values for individuals that were taking insulin or diabetic medications. Before performing any analysis, the participating studies made sure that each variable had a normal distribution, or transformed them to near normal. For example, a natural log transformation worked well for TG in general for all cohorts. In the FamHS, GLUC had a high kurtosis, thus applying a Box-Cox power transformation it was found, that $1 /$ GLUC $^{2}$ transformation worked well in acquiring a 
near-normal distributed GLUC. As a result, for any bivariate correlations in the FamHS that included GLUC, correlations coefficients were multiplied by $(-1)$, because power transformation for GLUC reversed the sign compared to original corresponding correlations. As an empirical check, when compared to FHS, the GLUC correlations in FamHS were very similar, although a transformation of GLUC was implemented in the FamHS. In addition, phenotypes were adjusted for polynomial age trend (age and age ${ }^{2}$ ), sex and important study specific covariates (e.g. field center), which were included in the regression model if $\mathrm{p}<$ 0.05 for generating the final data for analysis: standardized residuals, i.e. with mean 0 and variance of 1 .

In the Supplemental Tables 9-22, we present statistics for individual studies for (A) original variables, (B) original variables adjusted only for medication use, and (C) residuals from regression with mean 0 and variance 1 of variables obtained from adjusting (B) data for additional covariates as mentioned above. In the correlation statistical analyses we use the standardized final residuals labelled as the (C) set of data.

\section{Correlation statistical analysis and simulations}

We grouped participants' data in strata with- and without MetS ( $\mathrm{M}_{1}$ versus $\left.\mathrm{M}_{0}\right)$, for analyzing mean differences of inflammatory markers in these two subgroups for each cohort. We used (B) data and pooled t-test for testing mean differences between the two: $\left(x_{1}{ }^{-}\right.$ $\left.-x_{2}\right)$, with sample sizes $n_{1}$ and $n_{2}$ via $t=\frac{\left(\bar{x}_{1}-\bar{x}_{2}\right)}{s_{p} * \sqrt{\frac{1}{n_{1}}+\frac{1}{n_{2}}}}$, where $s_{p}=\sqrt{\frac{\left(n_{1}-1\right) * s_{1}^{2}+\left(n_{2}-1\right) * s_{2}^{2}}{n_{1}+n_{2}-2}}$ is the pooled standard deviation and $n_{1}+n_{2}-2$ degrees of freedom. In general, the MetS subgroup sample size was smaller than non-MetS one, but the variances between $\mathrm{M}_{1}$ and $\mathrm{M}_{0}$ subgroups were similar. The mean differences of two groups $\mathrm{p}$-values were tested against a conservative Bonferroni $\mathrm{p}$-threshold for $\mathrm{a}=0.05$ experimentwise, which corresponded for 53 tests to a $\mathrm{p}=9.43 \mathrm{e}-04$. Statistics of MetS, its risk factors as well as of inflammatory markers by cohort are summarized in Figure 1 and Supplemental Figures 1, (a-g). The inflammatory markers boxplot graph comparisons were built by using simulations via "rnorm" function in R with mean, standard deviation and sample size corresponding to subgroups with- and without MetS from the original data, (because in this collaboration we did not have direct access and could not pool original data at the participants' level). The above analysis was followed by correlation analyses (including up to 17 traits), performed with (C) data (defined at the end of Methods.2) near normally distributed, adjusted for medication use and covariates. All pairwise correlations were performed using Pearson correlation procedure (using SAS v. 9.3 or R v. 2.15.1, presented in Supplemental Tables 9-22).

We then used two parallel approaches, simulation and Fisher's Z-transformation, to generalize pairwise average correlations over all studies and to confirm our results. First, simulation processes were implemented to produce the average correlation matrix and the final correlated simulated data across all studies ( $N>85,500$ individuals) based on the (C) set of data. Simulation 1 was performed following these steps: using N (largest number of participants per study) and variance-covariance matrices (from above single studies) we 
simulated multivariate normal distributions with mean 0 and variance of 1 , of dimension (pvariables, $\mathrm{N}$-participants) for each study, using an $\mathrm{R}$ multivariate normal generating ("mvrnorm") function of the MASS library [39]. Since in simulations we used the largest number of participants per study, next, we introduced (in random patterns) missing values in traits when they were not available in all participants of a specific cohort. Thus, 100 replications of simulated data imitated correlations and sample size of the original cohorts. When pooled they formed all studies' set. These data represented all traits, but with corresponding per trait missing values. Correlations of simulated data were evaluated via Pearson pairwise correlation, which produced a full variance-covariance matrix, representing a simulated approximation of the average correlation matrix of single studies. The covariance matrix (correlations among metabolic traits, metabolic traits and inflammatory markers, and among inflammatory markers) of simulation 1 are presented in Table 2. Next, simulation 2 (again 100 replications) were implemented by using the first simulation's average variance-covariance matrix, to produce multivariate standardized normal variables with $\mathrm{p}=16$ variables and $\mathrm{N}>85,500$ individuals and no missing values. Simulation 2 with 100 replications were used to conduct factor analyses.

Second, we performed Fisher's Z-transformation to average correlations of standardized final residuals of the (C) set of data (Supplemental Table 2). Assuming that correlations of any two independent bivariate samples $\left(r_{1}\right.$ and $r_{2}$ ) of $n_{1}$ and $n_{2}$ sample sizes for the same trait combinations are random samples from a larger population, a combined correlation estimate $(r)^{-}$can be computed. Application of the $Z$ transformation of the two sample correlations follows: $Z_{1}=\tanh ^{-1}\left(r_{1}\right)$ and $Z_{2}=\tanh ^{-1}\left(r_{2}\right)$, where $\tanh$ is hyperbolic tangent and the $\mathrm{Z}$ can be calculated as $Z=0.5 \ln \left(\frac{1+r}{1-r}\right)=\operatorname{artanh}(r)$, where $\operatorname{artanh}$ is hyperbolic arctangent applied to each correlation coefficient. The weighted average $Z$ of the corresponding $\mathrm{Z}$ values is

$$
\bar{Z}=\frac{\left(n_{1}-3\right) Z_{1}+\left(n_{2}-3\right) Z_{2}}{n_{1}+n_{2}-6},
$$

where the weights are inversely proportional to their variances $\left(V Z^{-}=1 /\left(n_{1}+n_{2}-6\right)\right)$. Thus, a combined correlation estimate is $r=\tanh (Z)$. We extended averaging correlation coefficients for each bivariate trait combination to include up to 14 cohorts' correlation estimations, by writing a SAS macro program that implements Fisher's Z-transformation averaging via SAS MIANALYSE procedure. The IL-10 was dropped from these analyses, because it was present in only one study.

\section{Factor analysis}

Factor analyses with "Varimax" rotation were performed in SAS, v. 9.3. The purpose of using a multivariate statistical analysis was to identify latent clusters of traits that may help in identifying MetS and inflammatory markers underlying etiology. "Varimax" rotation creates orthogonal clusters of correlated variables. The objective is to maximize the independence of the clusters of correlated variables that contribute onto specific factors. An absolute value of a loading 0.4 or larger (which represents a correlation of an original 
variable to a factor when the data are standardized) is considered in the scale of correlations as a significant contribution. To account for the stochastic process in the 100 simulations, 100 factor analyses $(\mathrm{p}=16, \mathrm{~N}>85,500)$ with "Varimax" rotation were considered (Supplemental Figure 2). A coefficient of congruence was calculated as:

$\left(C C=\frac{\sum_{n=1}^{\text {ntraits }} l_{1} l_{2}}{\sqrt{\left(\sum_{n=1}^{\text {ntraits }} l_{1}^{2}\right)\left(\sum_{n=1}^{\text {ntraits }} l_{2}^{2}\right)}}\right)$, where $l_{1}$ represents loadings of a factor in a replication and $l_{2}$ represents loadings of a similar factor in another replication and ntraits is the number of traits contributing to a particular factor [40]. This similarity coefficient was calculated for all similar factors in the 100 replications (respectively $100 * 99 / 2=4950$ times, as an average similarity measure of comparable factor configurations in the simulations (Supplemental Table 3).

The average correlations among eight metabolic traits and nine inflammatory markers predict to some extent, especially via factor analyses, which trait combinations are useful and may reflect underlying MetS etiology, out of 130,305 possible trait combinations.

\section{Correlated meta-analysis}

Pleiotropic effects can result from a single pleiotropic locus (SNP/gene) affecting different traits, or from a group of alleles at distinct loci (SNPs/genes), but in linkage disequilibrium (statistical nonindependence) [41]. While examples of studies focused on pleiotropy based on published results [42, 43], as well as methods on linked pleiotropic loci exist [44, 45], our study focuses only on single pleiotropic sites (single SNPs) and the corresponding mapped genes, that associate simultaneously with metabolic traits and inflammatory markers as well as takes advantage of correlated meta-analyses.

We performed correlation analysis of 8 metabolic traits and 9 inflammatory markers, as a premise in identifying useful combinations that may help in discovering genetic pleiotropy. Based on such analysis we had selected 8 trait combinations for follow-up. This large number of results combined requires an unbiased method for meta-analyzing them. When meta-component scans are not independent, it can inflate type-I error, since at each location in the genome, a false-positive finding for one of the scans has an enhanced probability of being a false positive in any correlated scan. Province, and Province and Borecki [31, 32] developed a method for correcting bias via a correlated meta-analysis, which only requires the GWAS results and does not need the individual genotype/phenotype data. The basic idea is that for a trait of interest, the vast majority of the genome is under the null hypothesis of no genotype-phenotype association, which is only mildly contaminated with a relatively few SNPs that are under the alternative. Thus, the method performs sampling of GWAS genome via the polychoric correlation estimator [46], (using SAS PROC FREQ). It is the estimate of the $\mathrm{NxN}$ correlation matrix, $\Sigma$ between $\mathrm{N}$ scans, that is used to correct the final metaestimates for this correlation.

In this article, the meta-analyses were based on p-values combinations, which involved the Fisher's 1925 [47] method of combining p-values at each location of the genome [48]. This technique uses the fact that for $\mathrm{N}$ scans, $\sum-2 \ln \left(p_{i}\right) \sim \chi^{2}$ with $2 \mathrm{n}$ degrees of freedom, so the tail probability provides the meta-analysis p-value. Unfortunately, in the case of correlated 
GWAS, this sum is no longer distributed as a simple chi-square. Instead, in the correlated meta-analysis method, Province uses an inverse-normal transform, $Z_{i}=\phi^{-1}\left(p_{i}\right)$ forming the $\mathrm{N}$ dimensional vector $\underline{Z}$ of all $Z_{i}$ s. He then applies the basic theorem of multidimensional statistics that for matrix $\underline{\mathrm{D}}$, if $\underline{\mathrm{Z}} \sim \mathrm{N}(\underline{0}, \Sigma)$ then $\underline{\mathrm{D}} \underline{\mathrm{Z}} \sim \mathrm{N}(\underline{0}, \underline{\mathrm{D} \Sigma \mathrm{D}})$ '). In particular, when $\mathrm{D}$ is a $1 \times \mathrm{N}$ vector of all 1's, $\operatorname{SUM}(\underline{Z})=\underline{\mathrm{D}} \underline{\mathrm{Z}} \sim \mathrm{N}(0, \operatorname{SUM}(\Sigma))$, whose tail probability gives the $\mathrm{Z}$ meta-analysis p-value. In this case, for estimating $\Sigma$, the SNP p-values are dichotomized across the genome as ( $\mathrm{P} \leq 0.5 ; \mathrm{P}>0.5$ ). The software was developed in SAS by Province [31] and an interface was built with SAS/InterNet to perform parallel computing of each meta-analysis within the Division of Statistical Genomics, Washington University computing cluster.

\section{Bioinformatics of selected genes}

Another approach we used to appraise pleiotropy was searching Gene Entrez of NCBI (http://www.ncbi.nlm.nih.gov/gene/) for genes related to each of the traits studied: "body mass index", "waist circumference", "high density lipoprotein cholesterol", "triglycerides", "insulin", "glucose", "systolic blood pressure", "diastolic blood pressure", "fibrinogen", "Creactive protein", "plasminogen activator 1", "interleukin 6", "interleukin 10", "intercellular adhesion molecule 1", "tumor necrosis factor alpha", "adiponectin" and "white blood cell counts". Our search was limited only to human, mouse and rat species. Identified genes represent publication evidence of their contribution to a trait based on linkage, association, function, expression etc. All single traits gene lists were merged by gene name and selected for most contributions among metabolic traits and inflammatory markers, selected with a minimum threshold of 8 contributions between the two of them (Supplemental Table 6).

For the same terms, searches were implemented also at www.genome.gov/26525384. These data represent large genome wide studies with at least 100,000 SNPs and with a high statistical significance in the overall (initial GWAS + replication) population [49]. Genes identified as possible candidates were checked via Association Results Browser of dbGaP of NCBI http://www.ncbi.nlm.nih.gov/projects/gapplusprev/sgap_plus.htm. The same database was used to identify genes reported to associate with "metabolic syndrome". Results are reported in Supplemental Tables 7 and 8. The SNPs were checked if they served as eQTLs based on the eQTL NCBI database (http://www.ncbi.nlm.nih.gov/gtex/GTEX2/gtex.cgi.

The importance of gene lists identified was mined by means of GeneGO (http:// thomsonreuters.com/products_services/science/systems-biology/) and Literature Lab of ACUMENTA (http://acumenta.com/) software. The GeneGO, enrichment analysis consists of matching gene IDs of possible targets for the "common", "similar" and "unique" sets with gene IDs in functional ontologies in MetaCore, MetaDrug, MetaBase, Specialty modules, and System toxicology. The probability of a random intersection between a set of IDs the size of target list with ontology entities is estimated in p-value of hypergeometric intersection. The lower p-value means higher relevance of the entity to the dataset, which shows in higher rating for the entity. Literature Lab on the other hand, is an interface between experimentally-derived gene lists and scientific literature in a curated vocabulary of 24,000 biological and biochemical terms. It employs statistical and clustering analysis on over 14 million PubMed abstracts (01/01/90 to the present) to identify pathways (809 
pathways), diseases, compounds, cell biology and other areas of biology and biochemistry. The analysis engine compares statistically the submitted gene set to 1,000 random gene sets generated on-the-fly to identify term relationships that are associated with the gene set more than by chance alone.

\section{RESULTS}

\section{Epidemiological associations between inflammatory markers and MetS}

Using data from more than 85,500 participants across 14 cohorts (Table 1.a), we assessed at the phenotypic level the associations between 9 inflammatory markers CRP, FIB, PAI-1, IL-6, IL-10, ICAM-1, WBCC, TNFA and ADIP and MetS. Metabolic traits studied were BMI, WAIST, HDLC, TG, GLUC, INS, SBP and DBP (Supplemental Table 1). The mean age varied from $25(\mathrm{SD}= \pm 3)$ years in the CARDIA study to $74(\mathrm{SD}= \pm 8)$ years in the Rotterdam Study. These 14 studies capture a range of MetS (NCEP criteria) prevalence, from $2.4 \%$ in the baseline measurement of CARDIA-EA to $58.9 \%$ in GENOA-EA. The prevalence of MetS and its risk factors, as well as the mean levels of inflammatory markers in individuals with and without MetS, are summarized for two representative studies (the Family Heart Study and the Framingham Heart Study in Figure 1, and for all cohorts in the Supplemental Figures $1(\mathrm{a}-\mathrm{g})$. Overall, when comparing mean levels of inflammatory markers in individuals with MetS to those without, significant differences (passing Bonferroni threshold, $\mathrm{p} \leq 9.43 \times 10^{-4}$ ) were observed between the two strata in $85 \%$ (45 out of 53) of comparisons. FIB, CRP, PAI-1, ICAM-1, WBCC and TNFA mean levels were higher, whereas ADIP mean level was lower in individuals with MetS. There were also exceptions such as IL-10 (present only in one study), which did not show significant mean differences between individuals with and without MetS.

\section{Correlations among metabolic traits and inflammatory markers}

We calculated the pair-wise correlations between traits measured within individual studies (Supplemental Tables 9-22). The generalization of the within-study trait correlation to a global average correlation matrix was used to prioritize combinations of metabolic traits and inflammatory markers for subsequent correlated meta-analyses to evaluate the hypothesis of genetic pleiotropic associations between MetS risk factors and inflammatory markers. The estimation of average correlations across studies was approached with two methods. First, we simulated standardized normal variables with mean 0 and variance 1 based on the correlations and sample size (with missing values) of individual studies, because the original data at the participant level were not available (Methods.3). The overall average Pearson pairwise correlations were estimated from 100 replications of simulations with more than 85,500 individuals per replication (Table 2). Second, using Fisher's Z-transformation (Methods.3) we combined original correlations of single studies to an overall average correlation coefficients matrix. The average estimated values of correlation coefficients resulting from the two methods (Table 2 and Supplemental Table 2) were similar. Pertinent and significant correlations between inflammatory markers and metabolic traits were (1) FIB and CRP with all metabolic traits studied; (2) ICAM-1 and TNFA with HDLC and TG; and (3) ADIP and WBCC with WAIST, HDLC, TG and INS. 
Additionally, based on the overall studies average correlations, we built a second batch of simulated data for all traits. These simulations had 100 replications, each trait with a mean 0 and standard deviation of 1 with more than 85,500 individuals per replication and this time with no missing observations. We performed with them factor analyses (Methods.4), which gave us a second opportunity to identify additional priority combinations of traits as shown in the Supplemental Figure 2. Factor 1 represented a combination of (4) BMI, WAIST, INS, CRP, PAI-1 and weaker contributions of HDLC and TG; (5) weak contributions of BMI and WAIST were associated in Factor 2 with strong contributions of FIB, CRP, IL-6 and WBCC; (6) TG and less so HDLC, contributed along with CRP and WBCC in Factor 4; (7) HDLC and TG with PAI1 and ADIP in factor 5, and (8) GLUC and INS contributed to Factor 6 along with PAI-1. Supplemental Table 3 shows results of the coefficients of congruence for factors derived across replications (CC, Methods.4). The congruence of factor 1 across replications was high $(\mathrm{CC}=0.99)$. Factor 3 had only contributions from blood pressure and no noteworthy contributions of inflammatory markers and thus was not considered for follow-up in the correlated meta-analyses. As a result eight trait clusters were selected for correlated meta-analyses.

\section{Correlated phenotype-GWAS meta-analyses}

Finally, we implemented nine correlated meta-analyses (Methods.5), representing eight traitcombinations predicted from Results.2, and one including all variables. We utilized GWAS meta-summary-results from individual traits published mainly by large consortia (Table 1.b) for 8 metabolic traits (BMI [23], WAIST [33], HDLC and TG [24], GLUC and INS [20], SBP and DBP [22]), and 6 inflammatory markers (CRP [25], PAI-1 [26], ICAM-1 [28], WBCC [27], ADIP [34] and IL-6 [35]). The significance threshold of meta-analyses was set at $-\log _{10} \mathrm{p} \geq 8$. In addition, results were filtered requiring at least one metabolic trait and at least one inflammatory marker had an individual trait significance of $-\log _{10} \mathrm{p} \geq 3$. After selecting the lead SNP for each locus fulfilling the above three conditions, 130 unique SNPs remained, each simultaneously associating to at least one metabolic trait and one inflammatory marker (pleiotropic associations per variant). We infer for each SNP the corresponding mapped gene underlying such pleiotropic association (Supplemental Table 4). Of the 130 unique mapped genes, 25 mapped genes were selected as candidates for MetS, because each corresponding SNP showed at least two associations to metabolic traits from our analyses or GWAS literature and at least one association with inflammatory markers (Table 3). The 25 genes represent 15 distinct genomic loci with associations with MetS risk factors and inflammatory markers. A short description of the known functions of these 25 genes is provided in Table 4, and additional evidence is summarized in Table 5, Supplemental Table 5 and Figure 2, including annotation from the ENCODE by using HaploReg [50] and RegulomeDB [51] software and their additional databases.

As shown in Figure 2, specific SNPs based on their pleiotropic associations were classified in three main groups. The first group of pleiotropic associations for lipids and inflammation, included a SNP mapped to MACF1 [52] [53] and another SNP mapped to KIAA0754 on chromosome 1. Both mapped genes associated with HDLC and with WAIST, TG, GLUC and CRP. Furthermore on chromosome 2, a rich strand ( 1.2M bps in length) of 23 contiguous genes, from $T C F 23$ to $B R E$ was associated with TG and CRP. This region 
contains rs 1260326 of $\boldsymbol{G C K R}$, which encodes a missense change Leu446Pro, associated with both TG [24] and CRP [25]. Another independent group of SNPs on chromosome 2 mapped to genes GRB14 and COBLL1, positioned about 4.7K bps apart and each associated with HDLC, TG, PAI-1 and ADIP. A SNP near LOC646736 ( 23K bps), showed pleiotropic associations with HDLC, TG and ADIP. The LOC646736 is an uncharacterized gene on chromosome 2 located $\sim 528 \mathrm{~K}$ bps from the IRS1 gene. Intronic variants of $\boldsymbol{B A Z 1 B}$, $\boldsymbol{B C L 7 B}, \boldsymbol{T B L 2}$ and MLXIPL (7q11.23) were associated with TG, HDLC and CRP. An untranslated variant of $\boldsymbol{L P L}$ (8p22) was associated with HDLC, TG and CRP. TOMM40 (19q13) showed similar phenotypic association patterns. Rs10808546 about 45K bps from neighboring TRIB1 (8q24.13) was associated with TG, HDLC [24], ADIP and PAI-1. An intron SNP of ZNF664 (12q24.31) was associated with TG, HDLC and ADIP.

The second group with pleiotropic associations for adiposity/obesity and inflammation included $\boldsymbol{T F A P 2 B}$ (6p12), where its corresponding SNP was significantly associated with BMI, WAIST and CRP; selected SNPs corresponding to HECTD4 (12q24.13) and PTPN11 (12q24) were associated with ICAM-1, DBP, SBP, HDLC, BMI and WAIST, while an intron variant of $\boldsymbol{F T O}$ (16q12.2) was associated with BMI, WAIST, CRP and INS.

The third group of mapped genes showed pleiotropic associations for adiposity/obesity, lipids and inflammation. Among them were a missense variant rs 13107325 of SLC39A8 (4q22-q24), that associated with HDLC [24], BMI, ADIP, SBP, DBP and WAIST. The same SNP was previously reported in association with blood pressure, hypertension (HTN) [54], and BMI [23]. Three SNPs mapping respectively to NELFE, SKIV2L and STK19 (6p21) associated each to TG, BMI, WAIST, SBP, PAI-1 and WBCC. They are located in the class III region of the major histocompatibility complex of chromosome 6, close to the C2 gene. An intron SNP of PDXDC1 (16p13.11) was associated with ADIP, WAIST and TG. Finally, rs6567160 mapped to MC4R (18q22) was associated with BMI, WAIST, CRP, HDLC and TG.

\section{Bioinformatics analyses}

We searched the literature for all sources of publications that associated genes with effects on both metabolic traits and inflammatory markers. If the same gene is published to affect different traits then it supports the pleiotropy hypothesis. First, keyword searches based on single trait labels (Methods.6) using Gene Entrez of NCBI produced a list of 770 genes that had a relationship with at least one of the eight metabolic traits and at least one of the nine inflammatory markers. Of these, 48 putative pleiotropic genes were ranked with a total number of $\geq 8$ associations with metabolic traits and inflammatory markers keyword searches, sourced from three species: human, mouse and/or rat (Supplemental Table 6). Highest ranked for possible pleiotropic effects were the $A D I P Q, P P A R G$ and $L E P$ genes. Of this list through literature search, APOE, FTO, MMP 9 and VEGFA overlapped with our 130 pleiotropic gene list (Supplemental Table 4).

A second source of pleiotropic candidate genes was selected from previous GWAS literature (Methods.6 and Supplemental Table 7). Eleven genes in this list showed association with a single inflammatory marker, but with up to four associations with metabolic traits. Among 
them, GCKR was associated with four metabolic traits and CRP, while TRIB1 and TOMM4O were associated with HDLC, TG and ADIP and CRP, respectively. With the exception of CSMD1, the remaining ten genes (GCKR, IRS1, LYPLAL1, TRIB1, APOE, TOMM4O, $P P P 1 R 3 B, P E P D, B C L 7 B, T M E M 18$ ) are present in the list of 130 pleiotropic candidate genes of metabolic traits and inflammatory markers.

A third source of pleiotropic candidate genes was the gene search for "metabolic syndrome" via dbGaP Association Results Browser, which includes findings of the Catalog of Published Genome-Wide Association Studies (Methods.6). This search yielded $30 \mathrm{MetS}$ candidate genes (Supplemental Table 8). The overlap: GCKR, C2orf16, ZNF512, TFAP2B, MLXIPL, LPL, TRIBI, MTNRIB, FTO, TOMM40, represents 33\% of the Browser MetS list and $7.7 \%$ of our 130' genes pleiotropic list (Supplemental Table 4).

GeneGO database pathway analysis was performed for our 130 candidate pleiotropic genes. The pathway map of "ZNF202 role in gene expression in atherosclerosis", was enriched for genes affecting lipid metabolism $\left(\mathrm{p}=7.0 \times 10^{-8}\right)$, while less significant $\mathrm{p}$-values were for other pathways. For process networks, the most common were those related to inflammation. Since HLA genes are quite enriched in these pathways, removal of 7 genes, whose names started with HLA, produced a list of 123 pleiotropic candidate genes. The pathway maps remained similar as above, however process networks changed to "Complement system" (Inflammation, $\mathrm{p}=5.7 \times 10^{-4}$ ), and "Blood vessel morphogenesis" (Development, $\mathrm{p}=1.2 \times 10^{-3}$ ). For the disease classification, GeneGO reports the top ranking diseases as "Metabolic Syndrome" ( $\mathrm{p}=1.2 \times 10^{-12}$, TRIP8, BMAL1, GCKR, C2orf16, LPL, MMP-9, HNF4-alpha, NTPBP, APOE, TRIPs, TFAP2A, ZNF512, VEGF-A, AP-2B, MC4R, Notch, RGPR, Galpha(s)-specific peptide GPCRs, FTO, HNF4, CCDC121), Obesity (p= $\left.6.1 \times 10^{-11}\right)$, "Coronary disease" $\left(\mathrm{p}=1.6 \times 10^{-8}\right)$, "Macular degeneration" $\left(\mathrm{p}=3.7 \times 10^{-8}\right)$ and T2D $\left(\mathrm{p}=7.5 \times 10^{-8}\right)$. In the GO processes, "Glucose homeostasis" $\left(\mathrm{p}=3.0 \times 10^{-9}\right)$, "Positive regulation of vascular permeability" $\left(\mathrm{p}=8.8 \times 10^{-9}\right)$ and "Regulation of insulin secretion" ( $\mathrm{p}=$ $4.0 \times 10^{-7}$ ) were ranked at the top.

The following gene list GCKR, TFAP2B, MLXIPL, LPL, TRIB1, FTO, TOMM40 represents $23 \%$ of Browser MetS list and $28 \%$ of our 25 MetS pleiotropic candidates (Table 3).

Bioinformatic analysis using GeneGO database for our $25 \mathrm{MetS}$ candidate genes shows that only a few contribute to the GeneGO Canonical pathway maps. PTPN11 and GRB14 are upregulated, part of the "Development Angiopoietin Tie2 signaling" (enrichment $\mathrm{p}=2.4 \mathrm{E}-04$ ), conveying anti-inflammatory action. PTPN11 is part of six other pathways, while $L P L$ is part of three pathways. GeneGO enrichment analysis ranked as the top diseases "Metabolic Syndrome" $\left(\mathrm{p}=9.0 \times 10^{-7}\right)$; "Obesity" $\left(\mathrm{p}=8.5 \times 10^{-7}\right)$; and "Insulin Resistance" $(\mathrm{p}=$ $\left.5.6 \times 10^{-7}\right)$. From our list, some of the genes also have been studied for pharmacologic applications. $L P L$ is a therapeutic drug target for ibrolipim (activation) and gemfibrozil (activation), while MC4R is a target for bremelanotide (activation) and PTPN11 is a target for stibogluconate (inhibition).

Using the Literature Lab software of ACUMENTA Biotech for an automated literature interrogation [55], the same list of 25 genes showed association, compared with 1000 random sets of genes, for overnutrition $(\mathrm{p}=0.0039)$, obesity $(\mathrm{p}=0.0041)$, nutrition disorders 
$(\mathrm{p}=0.0053)$, heart valve diseases $(\mathrm{p}=0.0112)$, and fatty liver $(\mathrm{p}=0.0124)$. The contributing genes in these disease-MeSH term clusters, ranked by the number of the corresponding publications, were for overnutrition: MC4R (46.3\%), FTO (42.4\%), LPL (10.4\%) and $M L X I P L(0.6 \%)$; similar genes were in ranking order for obesity and nutrition disorders; for heart valve diseases BAZ1B (47.0\%), PTPN11 (37.5\%), TBL2 (7.7\%), and BCL7B (6.6\%); and for fatty liver MLXIPL (89.5\%), LPL (8.0\%) and GCKR (1.8\%).

\section{DISCUSSION}

This is the first time that a large sample of more than 85,500 participants with 8 metabolic traits and 9 inflammatory markers is analyzed together with the purpose of understanding relationships of inflammatory markers and MetS. Mean levels of inflammatory markers FIB, CRP, PAI-1, ICAM-1, WBCC and TNFA were higher, while mean ADIP level was lower in individuals classified with MetS compared to those without. These differences reached statistical significance. We explored the pairwise average correlations of all traits over all 14 studies. Correlation estimates and factor analyses yielded eight trait-combinations out of 130,305 possible combinations between metabolic traits and inflammatory markers, which may reflect some of the genetic correlations.

This is also the first time that 8 metabolic traits and 6 inflammatory markers mainly from large consortia meta-analyses are used to search for pleiotropic associations between MetS and inflammation. The analyses yielded 130 top ranked mapped genes with putative pleiotropic associations among metabolic traits and inflammatory markers. Twenty-five variants with pleiotropic associations, each mapped by a single gene, were considered as contributors to MetS per se. We considered MetS candidate genes to be the ones associated with two or more MetS risk factors (from our study and GWAS literature), and with one or more inflammatory markers.

Based on these analyses we infer that a pleiotropic genetic architecture exists and contributes to MetS. But what exactly do we see as pleiotropy at the gene level? Here we focus on a cluster of genes located on 7q11.23. At first glance, genes $B A Z 1 B, B C L 7 B, T B L 2$ and MLXIPL, show pleiotropy by similarly associating TG, HDLC and CRP. A few SNPs of $B A Z 1 B$ were associated with TG [56], protein C [57], and serum urate concentration [58]. $B C L 7 B$ 's SNPs were associated with CRP [25] and with gamma-Glutamyltransferase [59]. $T B L 2$ was associated with TG $[24,60,61]$ and with HDLC [24]. MLXIPL was associated significantly with very low density lipoprotein (VLDL) [62], with MetS [63], with TG [64], and with gamma-Glutamyltransferase [65] (Table 5 and Supplemental Table 5). Deletions of the four above contiguous genes have been identified as causing a Williams-Beuren syndrome, a multisystem developmental disorder, where $75 \%$ of cases show severe GLUC intolerance [66]. BAZ1B and MLXIPL may serve as transcription factors. The rs17145750 of $M L X I P L$, based on regulomeDB shows some minimal regulatory signature, and from HaploReg software affects a PPAR motif [50]. The rest of the selected SNPs also have some minimal regulatory properties. The majority of the SNPs in the four genes are under two overlapping linkage disequilibrium blocks (HapMap figure not shown). It has been reported that MLXIPL protein forms a heterodimeric complex and activates, in a glucose-dependent manner, carbohydrate response element (ChoRE) motifs in the promoters of triglyceride 
synthesis genes. Thus, $M L X I P L$ plays a critical role in systemic glucose metabolism, by converting excess carbohydrates to TG by way of de novo lipogenesis [66-68]. Recently, Herman et al. [69] showed in mice that GLUT4, officially known as SLC2A4 (known to be used by insulin for stimulating glucose uptake), regulates the expression of MLXIPL. Donnelly et al. [70] studied 9 non-alcoholic fatty liver disease participants (with excess liver TG) and showed that about $26 \%$ of TG in the liver was result of de novo lipogenesis, $59 \%$ from serum nonesterified fatty acids, $15 \%$ from diet, and a similar pattern of isotope labelling in VLDL. Thus, concluding that de novo lipogenesis contributes to the accumulation of hepatic fat. Jeong et al. [71], studied expression of MLXIPL using ChIP-seq and identified 14 genes as direct targets that affect the paths from GLUC to TG. They also proposed that MLXIPL is an activator and repressor based on gene expression patterns of target genes. The role of MLXIPL is complex, because in C57BL/6 mice, global deficiency of MLXIPL leads to insulin resistance [67], while in obese mouse with $o b / o b$ background (leptin deficiency) [67] leads to improved hepatic steatosis and improved insulin resistance. Moreover, Benhamed at al. [66] proposed that MLXIPL in the mouse liver raises beneficial lipid species. Thus, the pleiotropic associations of MLXIPL are complex and contextdependent.

Our findings are supported by additional GWAS results for several genes of three major pleiotropic groups presented in Figure 2. A comprehensive GWAS and functional evidence is reported in Tables 4, 5 and Supplemental Table 5 as evidence supporting our findings grouped by pleiotropic genes for 1) lipids and inflammation, 2) adiposity/obesity and inflammation, and 3) lipids, adiposity/obesity and inflammation [12, 24, 34, 59, 63-65, 72122]. The power achieved by our study is owing to the use of the world's largest GWAS meta-analyses available (Table 1.b). Because results originate from different consortia, it is possible that studies included may overlap subjects for different traits. However, the approach of correlated meta-analysis we use corrects results if such correlation is present (Methods.5). Previous studies have shown that risk of MetS, is influenced by genes that affect individual MetS risk factors [30, 63].

An appealing characteristic of the 130 pleiotropic candidates (Supplemental Table 4) is that several mapped genes are particularly associated with adiponectin and HDLC. Studies have shown that HDLC is a critical risk factor for coronary heart disease. In four studies, an increase by $1 \mathrm{mg} / \mathrm{dL}$ in HDLC associated with 2-3\% decrease in coronary heart disease risk [123]. Large analyses, also support the importance of HDLC measurement in the risk assessment of heart disease [124, 125]. In parallel, increased levels of adiponectin are of interest. For example, Ye and Scherer [126] summarized effects of adiponectin by reviewing either recombinant adiponectin protein, or endogenously its overproduction. In adipose tissue, adiponectin lowers inflammation and increases glucose uptake, fat storage and adipogenesis; in muscle induces an increased fatty acid oxidation; in heart decreases injury and apoptosis; in endothelium decreases oxidative stress and increases angiogenesis and function; in liver increases insulin sensitivity and lowers gluconeogenesis and lipogenesis; in macrophages increases insulin sensitivity and lowers inflammation. Thus it remains to be investigated, if SNPs with pleiotropic associations to the two phenotypes HDLC and adiponectin are flagging any anti-inflammatory and/or MetS protective effects from these 
genes (LYPLAL1, GRB14, COBLL1, STAB1, NT5DC2, FAM13A, SLC39A8, ARL15, VEGFA, HCAR2 [127], ZNF664, CMIP [128], and PEPD [120, 129, 130]).

In the list of 130 pleiotropic genes, a few special patterns emerged. The SNPs reported in Supplemental Table 5 closer to LOC646736 and a little more distant to IRSI gene appear not to be eQTLs of IRSI based on the NCBI database (Methods.6). Co-localization might relate with evolutionary functional importance, which is observed in our data for gene clusters. For example, a missense SNP ( $r 1260326, \mathrm{~T}=0.3963)$ of $G C K R$ associated with similar traits as rs $1919127(\mathrm{C}=0.2647)$ a missense of $C 2$ orf 16 , also as rs23844656 $(\mathrm{G}=0.2642)$, an intron of ZNF512 and rs13002853 (G=0.2593) a variant of CCDC121; another cluster was for DNAH10, CCDC92, and ZNF664 on chromosome 12, and for HNF4A, PLTP, PCIF1, ZNF335 and MMP9 on chromosome 20. Such clustering patterns are similar to a pattern previously reported on chromosome 11 for APOA5, ZNF259, and BUD13, where a zinc finger protein probably controls the transcription of nearby genes [80]. It is possible that neighboring gene-variants produce similar results in the associations, because of conserved haplotypes. In the 130 pleiotropic genes, 11 transcription factors (HEYL, SEC16B, GTF3C2, ZNF512, GTF2H4, TFAP2B, BAZ1B, MLXIPL, ZNF664, MED24, HNF4A and ZNF335) represent about $8.5 \%$ of the list. Vaquerizas et al. [131] reported 1,391 high confidence loci that encode transcription factors, about $6 \%$ of the total of human protein coding genes. Thus the 130-genes' list shows patterns that might be common for function conservation. Another feature observed by comparison of 130 pleiotropic candidate genes with the 30 MetS candidate genes (Supplemental Table 8) was that, although APOA5 and its cluster, as well as CETP, LIPC, GALNT2 involved in lipid metabolism are considered contributors to MetS, based on our results they appear not associated directly with inflammation.

The present results suggest that pleiotropic genes play a role in MetS. About two-thirds of our $25 \mathrm{MetS}$ pleiotropic candidates have not previously implicated for MetS risk. Mapped loci represent MACF1\& KIAA0754, GRB14\& COBLL1\& LOC646736-IRS1, SLC39A8, NELFE \& SKIV2L \& STK19, BAZ1B\& BCL7B\& TBL2 \& MLXIPL, HECTD4\& PTPN11, and $Z N F 664$, where $M L X I P L$ is already published for its association with MetS with a pvalue < 0.01 [63]. They represent known loci identified as having multiple relationships at the level of single traits or T2D or CHD and not previously fully appreciated for their genetic pleiotropy. These findings summarized in Figure 2, reinforce the importance of inflammatory responses as correlates of MetS and suggest that pleiotropic loci and their pathways contribute to the correlated architecture of MetS.

Kristiansson et al. [63] replicated 22 previously identified susceptibility loci for individual MetS risk factors, when testing for associations with MetS individual risk factors or with orthogonal factors from factor analysis. Most of the identified loci associated with lipid phenotypes and none were associated with two or more orthogonal MetS factors. Also they did not find evidence of pleiotropy of these genes with obesity. By comparison, our study based on very large GWAS meta-analyses indicates, that some MetS genes may be associated with two or more MetS risk factors, including inflammatory markers. For example, MC4R (rs6567160) showed associations with WAIST, BMI, HDLC, TG and CRP; NELFE (rs419788), SKIV2L (rs437179), STK19 (rs389883) were associated with TG, WAIST, SBP, PAI-1, WBCC, and BMI; SLC39A8 (rs13107325) was associated with 
HDLC, BMI, WAIST, SBP, DBP and ADIP; and MACF1 (rs1537817) was associated with HDLC, CRP, TG, WAIST, and GLUC.

The bioinformatic research provided additional information not only in support to our findings, but also to a finer understanding of gene effects as is the case of $B A Z 1 B, P T P N 11$, $T B L 2, B C L 7 B$ for heart valve disease, and $M L X I P L, L P L$ and $G C K R$ in relation to fatty liver disease as revealed by the Literature Lab. In contrast, our literature Entrez gene search based on trait keywords produced a filtered list of 48 pleiotropic candidate genes (Supplemental Table 6), from human, mouse and/or rat research. The 48 genes' list can reflect also weakness. For example, if a gene association/effect is identified from a single study with a small sample size, the keyword search still considers it as a countable contribution. Regardless of this weakness, keyword searches revealed that other genes with pleiotropic effects among metabolic traits themselves and also with inflammation remain to be discovered.

In principle, genetic makeup and environment contribute to the occurrence of MetS, whereas total burden is related to number and direction of disease predisposing alleles one carries. Our inferences are based on meta-analyses of p-values, and do not account for direction of associations for each SNP across studies (because some studies did not share beta-s and corresponding standard errors). This may represent a weaknesses in our study, for it could produce significance with heterogeneity. To diminish false positives we filtered our results for associations based on a meta $-\log _{10} \mathrm{p} \geq 8$ and requiring individual associations of metabolic traits and inflammatory markers to have single trait-single SNP associations with $-\log _{10} p \geq 3$. We worked only with association GWAS meta-results mainly of large consortia, and because of not having access to raw data, it was not possible to evaluate mediation $[132,133]$. Because of large GWAS samples used, we expect follow up with functional tests can further elucidate the role of pleiotropy in MetS. In conclusion, several inflammatory markers are indeed part of metabolic syndrome. A pleiotropic genetic architecture exists and contributes to MetS. Among genes with pleiotropic associations in our study, specific alleles of the ones associating with ADIP and HDLC may further contribute in understanding how to protect from MetS.

\section{Supplementary Material}

Refer to Web version on PubMed Central for supplementary material.

\section{Authors}

Aldi T. Kraja ${ }^{1, \dagger,},{ }^{*}$, Daniel I. Chasman ${ }^{2,}{ }^{,}$, Kari E. North ${ }^{3,}{ }^{*}$, Alexander P. Reiner ${ }^{4,{ }^{*}}$, Lisa

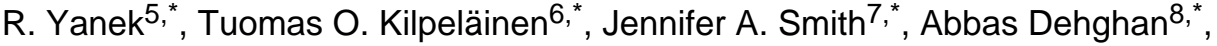
Josée Dupuis ${ }^{9,10}$, Andrew D. Johnson ${ }^{11}$, Mary F. Feitosa ${ }^{1}$, Fasil Tekola-Ayele ${ }^{12}$, Audrey Y. Chu ${ }^{2}$, Ilja M. Nolte ${ }^{13}$, Zari Dastani ${ }^{14}$, Andrew Morris ${ }^{15}$, Sarah A. Pendergrass ${ }^{16}$, Yan V. Sun ${ }^{17}$, Marylyn D. Ritchie ${ }^{18}$, Ahmad Vaez ${ }^{13}$, Honghuang Lin $^{19}$, Symen Ligthart ${ }^{8}$, Letizia Marullo ${ }^{15,20}$, Rebecca Rohde ${ }^{3}$, Yaming Shao ${ }^{3}$, Mark A. Ziegler ${ }^{21}$, Hae Kyung Im $^{22}$, Cross Consortia Pleiotropy (XC-Pleiotropy) Group, the Cohorts for Heart and Aging Research in Genetic Epidemiology (CHARGE), the 
Genetic Investigation of Anthropometric Traits (GIANT) Consortium, the Global Lipids Genetics Consortium (GLGC), the Meta-Analyses of Glucose and Insulinrelated traits Consortium (MAGIC), the Global BPgen (GBPG) Consortium, The ADIPOGen Consortium, the Women's Genome Health Study (WGHS), the Howard University Family Study (HUFS), Renate B. Schnabel ${ }^{23}$, Torben Jørgensen ${ }^{24,25}$, Marit E. Jørgensen ${ }^{26}$, Torben Hansen 6 , Oluf Pedersen 6 , Ronald P. Stolk ${ }^{13}$, Harold Snieder ${ }^{13}$, Albert Hofman ${ }^{8}$, Andre G. Uitterlinden ${ }^{27}$, Oscar H. Franco ${ }^{8}$, M. Arfan Ikram $^{8}$, J. Brent Richards ${ }^{14,28,29}$, Charles Rotimi ${ }^{12}$, James G. Wilson ${ }^{30}$, Leslie Lange $^{31}$, Santhi K. Ganesh ${ }^{32}$, Mike Nalls ${ }^{33}$, Laura J. Rasmussen-Torvik ${ }^{34}$, James S. Pankow ${ }^{35}$, Josef Coresh ${ }^{36}$, Weihong Tang ${ }^{35}$, W.H. Linda Kao ${ }^{37}$, Eric Boerwinkle ${ }^{38}$, Alanna C. Morrison ${ }^{38}$, Paul M. Ridker², Diane M. Becker ${ }^{5}$, Jerome I. Rotter $^{39}$, Sharon L.R. Kardia 7 , Ruth J.F. Loos ${ }^{40}$, Martin G. Larson ${ }^{10,41,{ }^{*}, \text { Yi-Hsiang }}$ $\mathrm{Hsu}^{42}$, Michael A. Province ${ }^{1}$, Russell Tracy ${ }^{43}$, Benjamin F. Voight ${ }^{44}$, Dhananjay

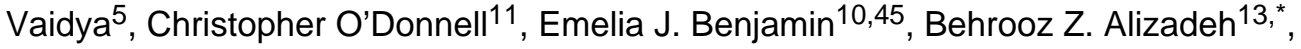

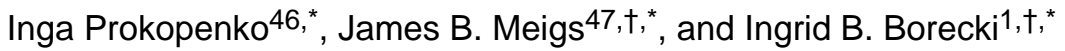

\section{Affiliations}

${ }^{1}$ Division of Statistical Genomics, Department of Genetics and Center for Genome Sciences and Systems Biology, Washington University School of Medicine, St. Louis, MO, USA 'Division of Preventive Medicine, Brigham and Women's Hospital and Harvard Medical School, Boston, MA, USA ${ }^{3}$ Department of Epidemiology and Carolina Center for Genome Sciences, Gillings School of Global Public Health, University of North Carolina at Chapel Hill, NC, USA ${ }^{4}$ Department of Epidemiology, University of Washington, Seattle, WA, USA ${ }^{5}$ Division of General Internal Medicine, Department of Medicine, Johns Hopkins University School of Medicine, Baltimore, MD, USA ${ }^{6}$ The Novo Nordisk Foundation Center for Basic Metabolic Research, Section of Metabolic Genetics, Faculty of Health and Medical Sciences, University of Copenhagen, Copenhagen, Denmark ${ }^{7}$ Department of Epidemiology, University of Michigan, Ann Arbor, MI, USA ${ }^{8}$ Department of Epidemiology, Erasmus Medical Center, Rotterdam, The Netherlands ${ }^{9}$ Department of Biostatistics, Boston University School of Public Health, Boston, MA, USA ${ }^{10}$ National Heart, Lung, and Blood Institute's and Boston University's Framingham Heart Study, Framingham, MA, USA ${ }^{11}$ National Heart, Lung and Blood Institute (NHLBI) Division of Intramural Research and NHLBI's Framingham Heart Study, Framingham, MA, USA ${ }^{12}$ Center for Research on Genomics and Global Health, National Human Genome Research Institute, National Institutes of Health, Bethesda, MD, USA ${ }^{13}$ Department of Epidemiology, University of Groningen, University Medical Center Groningen, Groningen, The Netherlands ${ }^{14}$ Department of Epidemiology, Biostatistics and Occupational Health. Jewish General Hospital, Lady Davis Institute, McGill University Montreal, Quebec, Canada ${ }^{15}$ The Welcome Trust Centre for Human Genetics, University of Oxford, Oxford, UK ${ }^{16}$ Department of Biochemistry and Molecular Biology, Eberly College of Science and The Huck Institutes of the Life Sciences, The Pennsylvania State University, PA, USA ${ }^{17}$ Department of Epidemiology, Rollins School of Public Health, and Department of Biomedical Informatics, School of Medicine, Emory University, Atlanta, GA, USA ${ }^{18}$ Department 
of Biochemistry and Molecular Biology, Pennsylvania State University, University Park, PA, USA ${ }^{19}$ Section of Computational Biomedicine, Department of Medicine, Boston University School of Medicine, Boston, MA, USA ${ }^{20}$ Department of Life Sciences and Biotechnology, University of Ferrara, Ferrara, Italy ${ }^{21}$ Division of Biostatistics, MSIBS Program, Washington University School of Medicine, St. Louis, MO, USA ${ }^{22}$ Department of Health Studies, University of Chicago, IL, USA ${ }^{23}$ Department of General and Interventional Cardiology University Heart Center Hamburg-Eppendorf, Hamburg, Germany ${ }^{24}$ Research Centre for Prevention and Health, Glostrup Hospital, Glostrup, Denmark ${ }^{25}$ Faculty of Helath Science, University of Copenhagen, Copenhagen, Denmark ${ }^{26}$ Steno Diabetes Center, Gentofte, Denmark ${ }^{27}$ Department of Internal Medicine, Erasmus Medical Center, Rotterdam, The Netherlands ${ }^{28}$ Department of Medicine, Human Genetics, Epidemiology and Biostatistics, McGill University, Canada ${ }^{29}$ Department of Twin Research, King's College, London, UK ${ }^{30}$ University of Mississippi, Medical Center, MS, USA ${ }^{31}$ Department of Genetics, University of North Carolina, NC, USA ${ }^{32}$ Department of Internal Medicine, University of Michigan, MI, USA ${ }^{33}$ Molecular Genetics Section, Laboratory of Neurogenetics, National Institute on Aging, NIH, Bethesda, MD, USA ${ }^{34}$ Northwestern University Feinberg School of Medicine, Chicago, IL, USA ${ }^{35}$ Division of Epidemiology and Community Health, University of Minnesota, Minneapolis MN, USA ${ }^{36}$ Department of Medicine, Epidemiology, Biostatistics, Johns Hopkins University Bloomberg School of Public Health, Baltimore, MD, USA ${ }^{37}$ Department of Epidemiology, Johns Hopkins Bloomberg School of Public Health, Baltimore, MD, USA ${ }^{38}$ Human Genetics Center, University of Texas-Houston Health Science Center at Houston, Houston TX, USA ${ }^{39}$ Institute for Translational Genomics and Population Sciences, Los Angeles Biomedical Research Institute (LA BioMed), Harbor-UCLA Medical Center, Torrance, CA, USA ${ }^{40}$ The Genetics of Obesity and Relate Metabolic Traits Program, The Charles Bronfman Institute for Personalized Medicine, The Mindich Child Health and Development Institute, The Icahn School of Medicine at Mount Sinai, New York, NY, USA ${ }^{41}$ Department of Mathematics and Statistics, Boston University, Department of Biostatistics, Boston University School of Public Health, Boston, MA, USA ${ }^{42} \mathrm{Hebrew}$ Senior Life Institute for Aging Research, Harvard Medical School and Molecular and Integrative Physiological Sciences, Harvard School of Public Health, Boston, MA, USA ${ }^{43}$ University of Vermont College of Medicine, Burlington, VT ${ }^{44}$ Department of Pharmacology and Department of Genetics, University of Pennsylvania - Perelman School of Medicine, Philadelphia PA, USA ${ }^{45}$ Cardiology and Preventive Medicine Sections, Department of Medicine, Boston University School of Medicine, Boston, MA, USA ${ }^{46}$ Department of Genomics of Common Diseases, School of Public Health, Imperial College London, London, W12 0NN, UK ${ }^{47}$ General Medicine Division, Massachusetts General Hospital and Harvard Medical School, Boston, MA, USA 


\section{Acknowledgments}

The authors express their gratitude to large meta-GWAS Consortia and studies for contributing results in the XCPleiotropy. They are recognized as contributing studies in the coauthorship. In addition we acknowledge the followings studies for contributing correlation analyses:

ARIC:

The Atherosclerosis Risk in Communities Study is carried out as a collaborative study supported by National Heart, Lung, and Blood Institute contracts (HHSN268201100005C, HHSN268201100006C, HHSN268201100007C, HHSN268201100008C, HHSN268201100009C, HHSN268201100010C, HHSN268201100011C, and HHSN268201100012C). This work is also funded in part by R01DK075681 (K.E.N.).

The authors thank the staff and participants of the ARIC study for their important contributions.

\section{CARDIA:}

Coronary Artery Risk in Young Adults was supported by University of Alabama at Birmingham (N01-HC-48047), University of Minnesota (N01-HC-48048), Northwestern University (N01-HC-48049), Kaiser Foundation Research Institute (N01-HC-48050), University of Alabama at Birmingham (N01-HC-95095), Tufts-New England Medical Center (N01-HC-45204), Wake Forest University (N01-HC-45205), Harbor-UCLA Research and Education Institute (N01-HC-05187), University of California, Irvine (N01-HC-45134, N01-HC-95100).

\section{GeneSTAR:}

GeneSTAR was supported by the National Heart, Lung, and Blood Institute (NHLBI) through the PROGENI (U01 HL72518) consortium as well as grants HL58625-01A1, HL59684, and HL071025-01A1, and a grant from the NIH/National Institute of Nursing Research (NR0224103). Additional support was provided by a grant from the NIH/National Center for Research Resources (M01-RR000052) to the Johns Hopkins General Clinical Research Center.

\section{GENOA:}

Support for the Genetic Epidemiology Network of Arteriopathy was provided by the National Heart, Lung and Blood Institute of the National Institutes of Health (HL054464, HL054457, HL054481, HL081331, and HL087660). We would also like to thank the families that participated in the GENOA study.

\section{FamHS:}

This work was supported in part by NIDDK grant 1R01DK8925601 (I.B.B.).

FHS:

This research was conducted in part using data and resources from the Framingham Heart Study of the National Heart Lung and Blood Institute of the National Institutes of Health and Boston University School of Medicine. The analyses reflect intellectual input and resource development from the Framingham Heart Study investigators participating in the SNP Health Association Resource (SHARe) project. This work was partially supported by the National Heart, Lung and Blood Institute's Framingham Heart Study (Contract No. N01-HC-25195) and its contract with Affymetrix, Inc for genotyping services (Contract No. N02-HL-6-4278). A portion of this research utilized the Linux Cluster for Genetic Analysis (LinGA-II) funded by the Robert Dawson Evans Endowment of the Department of Medicine at Boston University School of Medicine and Boston Medical Center. Also supported by National Institute for Diabetes and Digestive and Kidney Diseases R01 DK078616 and K24 DK080140 (J.B.M.), and 1RO1 HL64753, R01 HL076784, 1R01 AG028321, 1R01HL092577 (E.J.B.).

\section{INTER99:}

The Inter99 Study was initiated by Torben Jørgensen, Knut Borch-Johnsen, Hans Ibsen and Troels F. Thomsen. The steering committee comprises Torben Jørgensen, Knut Borch-Johnsen and Charlotta Pisinger. The phenotyping was financially supported by grants from the Danish Medical Research Council, The Danish Centre for Health Technology Assessment, Novo Nordisk, Copenhagen County, The Danish Heart Foundation, The Danish Pharmaceutical Association, The Augustinus Foundation, The Ib Henriksen Foundation, and the Becket Foundation. The genetic research was supported by grants from the Lundbeck Foundation (www.lucamp.org) and the Novo Nordisk Foundation (metabol.ku.dk). This work is carried out as a part of the research program of the UNIK: Food, Fitness \& Pharma for Health and Disease (see www.foodfitnesspharma.ku.dk). The UNIK project is supported by the Danish Ministry of Science, Technology and Innovation. 
LifeLines:

The LifeLines Cohort Study is supported by the Netherlands Organization of Scientific Research NWO (grant 175.010.2007.006), the Economic Structure Enhancing Fund (FES) of the Dutch government, the Ministry of Economic Affairs, the Ministry of Education, Culture and Science, the Ministry for Health, Welfare and Sports, the Northern Netherlands Collaboration of Provinces (SNN), the Province of Groningen, University Medical Center Groningen, the University of Groningen, Dutch Kidney Foundation and Dutch Diabetes Research Foundation. The authors wish to acknowledge the services of the LifeLines Cohort Study, the contributing research centers delivering data to LifeLines, and all the study participants.

RS:

The Rotterdam Study is supported by the Erasmus Medical Center and Erasmus University Rotterdam; the Netherlands Organization for Scientific Research (NWO); the Netherlands Organization for Health Research and Development (ZonMw); the Research Institute for Diseases in the Elderly (RIDE); the Netherlands Heart Foundation; the Ministry of Education, Culture and Science; the Ministry of Health Welfare and Sports; the European Commission; and the Municipality of Rotterdam.

Support for genotyping was provided by the Netherlands Organisation of Scientific Research NWO Investments (nr. 175.010.2005.011, 911-03-012), the Research Institute for Diseases in the Elderly (014-93-015; RIDE2), the Netherlands Genomics Initiative (NGI)/Netherlands Consortium for Healthy Aging (NCHA) project nr. 050-060-810. This work is supported also by NWO grant (veni, 916.12.154) and the EUR Fellowship (A.D.).

\section{WGHS:}

The WGHS is supported by HL043851 and HL080467 from the National Heart, Lung, and Blood Institute and CA047988 from the National Cancer Institute, and the Donald W. Reynolds Foundation, with collaborative scientific support and funding for genotyping provided by Amgen.

WHI:

The WHI program is funded by the National Heart, Lung, and Blood Institute, National Institutes of Health, U.S. Department of Health and Human Services through contracts HHSN268201100046C, HHSN268201100001C, HHSN268201100002C, HHSN268201100003C, HHSN268201100004C, and HHSN271201100004C. A listing of WHI investigators can be found at https://cleo.whi.org/researchers/Documents\%20\%20Write\%20a\%20Paper/WHI \%20Investigator\%20Short\%20List.pdf

Other:

This research was supported in part by the Intramural Research Program of the NIH, National Institute on Aging, Z01-AG000932-06, (M.N.). This study utilized the high-performance computational capabilities of the Biowulf Linux cluster (http://biowulf.nih.gov) at the National Institutes of Health, Bethesda, MD (M.N.).

\section{References}

1. Grundy SM, Hansen B, Smith SC Jr, Cleeman JI, Kahn RA. A. American Heart, L. National Heart, I. Blood, A. American Diabetes, Clinical management of metabolic syndrome: report of the American Heart Association/National Heart, Lung, and Blood Institute/American Diabetes Association conference on scientific issues related to management. Circulation. 2004; 109:551-556. [PubMed: 14757684]

2. Galassi A, Reynolds K, He J. Metabolic syndrome and risk of cardiovascular disease: a metaanalysis. The American journal of medicine. 2006; 119:812-819. [PubMed: 17000207]

3. Monda KL, North KE, Hunt SC, Rao DC, Province MA, Kraja AT. The genetics of obesity and the metabolic syndrome. Endocrine, metabolic \& immune disorders drug targets. 2010; 10:86-108.

4. Eckel RH, Grundy SM, Zimmet PZ. The metabolic syndrome. Lancet. 2005; 365:1415-1428. [PubMed: 15836891]

5. Lusis AJ, Attie AD, Reue K. Metabolic syndrome: from epidemiology to systems biology. Nature reviews. Genetics. 2008; 9:819-830.

6. Djousse L, Padilla H, Nelson TL, Gaziano JM, Mukamal KJ. Diet and metabolic syndrome. Endocrine, metabolic \& immune disorders drug targets. 2010; 10:124-137. 
7. Katzmarzyk PT, Leon AS, Wilmore JH, Skinner JS, Rao DC, Rankinen T, Bouchard C. Targeting the metabolic syndrome with exercise: evidence from the HERITAGE Family Study. Medicine and science in sports and exercise. 2003; 35:1703-1709. [PubMed: 14523308]

8. Tuttolomondo A, Pecoraro R, Di Raimondo D, Di Sciacca R, Canino B, Arnao V, Butta C, Della Corte V, Maida C, Licata G, Pinto A. Immune-inflammatory markers and arterial stiffness indexes in subjects with acute ischemic stroke with and without metabolic syndrome. Diabetology \& metabolic syndrome. 2014; 6:28. [PubMed: 24571954]

9. Tuttolomondo A, Di Raimondo D, Di Sciacca R, Pecoraro R, Arnao V, Butta C, Licata G, Pinto A. Arterial stiffness and ischemic stroke in subjects with and without metabolic syndrome. Atherosclerosis. 2012; 225:216-219. [PubMed: 23031362]

10. Johnson LW, Weinstock RS. The metabolic syndrome: concepts and controversy Mayo Clinic proceedings. Mayo Clinic. 2006; 81:1615-1620.

11. Kahn R, Buse J, Ferrannini E, Stern M. A. American Diabetes, D. European Association for the Study of, The metabolic syndrome: time for a critical appraisal: joint statement from the American Diabetes Association and the European Association for the Study of Diabetes. Diabetes care. 2005; 28:2289-2304. [PubMed: 16123508]

12. Henneman P, Aulchenko YS, Frants RR, van Dijk KW, Oostra BA, van Duijn CM. Prevalence and heritability of the metabolic syndrome and its individual components in a Dutch isolate: the Erasmus Rucphen Family study. Journal of medical genetics. 2008; 45:572-577. [PubMed: 18550697]

13. Kraja AT, Province MA, Arnett D, Wagenknecht L, Tang W, Hopkins PN, Djousse L, Borecki IB. Do inflammation and procoagulation biomarkers contribute to the metabolic syndrome cluster? Nutrition \& metabolism. 2007; 4:28. [PubMed: 18154661]

14. Wannamethee SG, Lowe GD, Shaper AG, Rumley A, Lennon L, Whincup PH. The metabolic syndrome and insulin resistance: relationship to haemostatic and inflammatory markers in older non-diabetic men. Atherosclerosis. 2005; 181:101-108. [PubMed: 15939060]

15. Ridker PM, Wilson PW, Grundy SM. Should C-reactive protein be added to metabolic syndrome and to assessment of global cardiovascular risk? Circulation. 2004; 109:2818-2825. [PubMed: 15197153]

16. Hung J, McQuillan BM, Thompson PL, Beilby JP. Circulating adiponectin levels associate with inflammatory markers, insulin resistance and metabolic syndrome independent of obesity. International journal of obesity. 2008; 32:772-779. [PubMed: 18253163]

17. Matsushita K, Yatsuya H, Tamakoshi K, Wada K, Otsuka R, Takefuji S, Sugiura K, Kondo T, Murohara T, Toyoshima H. Comparison of circulating adiponectin and proinflammatory markers regarding their association with metabolic syndrome in Japanese men. Arteriosclerosis, thrombosis, and vascular biology. 2006; 26:871-876.

18. Sakkinen PA, Wahl P, Cushman M, Lewis MR, Tracy RP. Clustering of procoagulation, inflammation, and fibrinolysis variables with metabolic factors in insulin resistance syndrome. American journal of epidemiology. 2000; 152:897-907. [PubMed: 11092431]

19. Espinola-Klein C, Gori T, Blankenberg S, Munzel T. Inflammatory markers and cardiovascular risk in the metabolic syndrome. Frontiers in bioscience. 2011; 16:1663-1674.

20. Dupuis J, Langenberg C, Prokopenko I, Saxena R, Soranzo N, Jackson AU, Wheeler E, Glazer NL, Bouatia-Naji N, Gloyn AL, Lindgren CM, Magi R, Morris AP, Randall J, Johnson T, Elliott P, Rybin D, Thorleifsson G, Steinthorsdottir V, Henneman P, Grallert H, Dehghan A, Hottenga JJ, Franklin CS, Navarro P, Song K, Goel A, Perry JR, Egan JM, Lajunen T, Grarup N, Sparso T, Doney A, Voight BF, Stringham HM, Li M, Kanoni S, Shrader P, Cavalcanti-Proenca C, Kumari M, Qi L, Timpson NJ, Gieger C, Zabena C, Rocheleau G, Ingelsson E, An P, O'Connell J, Luan J, Elliott A, McCarroll SA, Payne F, Roccasecca RM, Pattou F, Sethupathy P, Ardlie K, Ariyurek Y, Balkau B, Barter P, Beilby JP, Ben-Shlomo Y, Benediktsson R, Bennett AJ, Bergmann S, Bochud M, Boerwinkle E, Bonnefond A, Bonnycastle LL, Borch-Johnsen K, Bottcher Y, Brunner E, Bumpstead SJ, Charpentier G, Chen YD, Chines P, Clarke R, Coin LJ, Cooper MN, Cornelis M, Crawford G, Crisponi L, Day IN, de Geus EJ, Delplanque J, Dina C, Erdos MR, Fedson AC, Fischer-Rosinsky A, Forouhi NG, Fox CS, Frants R, Franzosi MG, Galan P, Goodarzi MO, Graessler J, Groves CJ, Grundy S, Gwilliam R, Gyllensten U, Hadjadj S, Hallmans G, Hammond N, Han X, Hartikainen AL, Hassanali N, Hayward C, Heath SC, Hercberg S, Herder C, Hicks AA, 
Hillman DR, Hingorani AD, Hofman A, Hui J, Hung J, Isomaa B, Johnson PR, Jorgensen T, Jula A, Kaakinen M, Kaprio J, Kesaniemi YA, Kivimaki M, Knight B, Koskinen S, Kovacs P, Kyvik KO, Lathrop GM, Lawlor DA, Le Bacquer O, Lecoeur C, Li Y, Lyssenko V, Mahley R, Mangino M, Manning AK, Martinez-Larrad MT, McAteer JB, McCulloch LJ, McPherson R, Meisinger C, Melzer D, Meyre D, Mitchell BD, Morken MA, Mukherjee S, Naitza S, Narisu N, Neville MJ, Oostra BA, Orru M, Pakyz R, Palmer CN, Paolisso G, Pattaro C, Pearson D, Peden JF, Pedersen NL, Perola M, Pfeiffer AF, Pichler I, Polasek O, Posthuma D, Potter SC, Pouta A, Province MA, Psaty BM, Rathmann W, Rayner NW, Rice K, Ripatti S, Rivadeneira F, Roden M, Rolandsson O, Sandbaek A, Sandhu M, Sanna S, Sayer AA, Scheet P, Scott LJ, Seedorf U, Sharp SJ, Shields B, Sigurethsson G, Sijbrands EJ, Silveira A, Simpson L, Singleton A, Smith NL, Sovio U, Swift A, Syddall H, Syvanen AC, Tanaka T, Thorand B, Tichet J, Tonjes A, Tuomi T, Uitterlinden AG, van Dijk KW, van Hoek M, Varma D, Visvikis-Siest S, Vitart V, Vogelzangs N, Waeber G, Wagner PJ, Walley A, Walters GB, Ward KL, Watkins H, Weedon MN, Wild SH, Willemsen G, Witteman JC, Yarnell JW, Zeggini E, Zelenika D, Zethelius B, Zhai G, Zhao JH, Zillikens MC, Consortium D, Consortium G, Global BC, Borecki IB, Loos RJ, Meneton P, Magnusson PK, Nathan DM, Williams GH, Hattersley AT, Silander K, Salomaa V, Smith GD, Bornstein SR, Schwarz P, Spranger J, Karpe F, Shuldiner AR, Cooper C, Dedoussis GV, Serrano-Rios M, Morris AD, Lind L, Palmer LJ, Hu FB, Franks PW, Ebrahim S, Marmot M, Kao WH, Pankow JS, Sampson MJ, Kuusisto J, Laakso M, Hansen T, Pedersen O, Pramstaller PP, Wichmann HE, Illig T, Rudan I, Wright AF, Stumvoll M, Campbell H, Wilson JF, Bergman RN, Buchanan TA, Collins FS, Mohlke KL, Tuomilehto J, Valle TT, Altshuler D, Rotter JI, Siscovick DS, Penninx BW, Boomsma DI, Deloukas P, Spector TD, Frayling TM, Ferrucci L, Kong A, Thorsteinsdottir U, Stefansson K, van Duijn CM, Aulchenko YS, Cao A, Scuteri A, Schlessinger D, Uda M, Ruokonen A, Jarvelin MR, Waterworth DM, Vollenweider P, Peltonen L, Mooser V, Abecasis GR, Wareham NJ, Sladek R, Froguel P, Watanabe RM, Meigs JB, Groop L, Boehnke M, McCarthy MI, Florez JC, Barroso I. C. Anders Hamsten on behalf of Procardis, M. investigators. New genetic loci implicated in fasting glucose homeostasis and their impact on type 2 diabetes risk. Nature genetics. 2010; 42:105-116. [PubMed: 20081858]

21. Ingelsson E, Langenberg C, Hivert MF, Prokopenko I, Lyssenko V, Dupuis J, Magi R, Sharp S, Jackson AU, Assimes TL, Shrader P, Knowles JW, Zethelius B, Abbasi FA, Bergman RN, Bergmann A, Berne C, Boehnke M, Bonnycastle LL, Bornstein SR, Buchanan TA, Bumpstead SJ, Bottcher Y, Chines P, Collins FS, Cooper CC, Dennison EM, Erdos MR, Ferrannini E, Fox CS, Graessler J, Hao K, Isomaa B, Jameson KA, Kovacs P, Kuusisto J, Laakso M, Ladenvall C, Mohlke KL, Morken MA, Narisu N, Nathan DM, Pascoe L, Payne F, Petrie JR, Sayer AA, Schwarz PE, Scott LJ, Stringham HM, Stumvoll M, Swift AJ, Syvanen AC, Tuomi T, Tuomilehto J, Tonjes A, Valle TT, Williams GH, Lind L, Barroso I, Quertermous T, Walker M, Wareham NJ, Meigs JB, McCarthy MI, Groop L, Watanabe RM, Florez JC. M. investigators, Detailed physiologic characterization reveals diverse mechanisms for novel genetic Loci regulating glucose and insulin metabolism in humans. Diabetes. 2010; 59:1266-1275. [PubMed: 20185807]

22. Newton-Cheh C, Johnson T, Gateva V, Tobin MD, Bochud M, Coin L, Najjar SS, Zhao JH, Heath SC, Eyheramendy S, Papadakis K, Voight BF, Scott LJ, Zhang F, Farrall M, Tanaka T, Wallace C, Chambers JC, Khaw KT, Nilsson P, van der Harst P, Polidoro S, Grobbee DE, Onland-Moret NC, Bots ML, Wain LV, Elliott KS, Teumer A, Luan J, Lucas G, Kuusisto J, Burton PR, Hadley D, McArdle WL, Brown M, Dominiczak A, Newhouse SJ, Samani NJ, Webster J, Zeggini E, Beckmann JS, Bergmann S, Lim N, Song K, Vollenweider P, Waeber G, Waterworth DM, Yuan X, Groop L, Orho-Melander M, Allione A, Di Gregorio A, Guarrera S, Panico S, Ricceri F, Romanazzi V, Sacerdote C, Vineis P, Barroso I, Sandhu MS, Luben RN, Crawford GJ, Jousilahti P, Perola M, Boehnke M, Bonnycastle LL, Collins FS, Jackson AU, Mohlke KL, Stringham HM, Valle TT, Willer CJ, Bergman RN, Morken MA, Doring A, Gieger C, Illig T, Meitinger T, Org E, Pfeufer A, Wichmann HE, Kathiresan S, Marrugat J, O'Donnell CJ, Schwartz SM, Siscovick DS, Subirana I, Freimer NB, Hartikainen AL, McCarthy MI, O'Reilly PF, Peltonen L, Pouta A, de Jong PE, Snieder H, van Gilst WH, Clarke R, Goel A, Hamsten A, Peden JF, Seedorf U, Syvanen AC, Tognoni G, Lakatta EG, Sanna S, Scheet P, Schlessinger D, Scuteri A, Dorr M, Ernst F, Felix SB, Homuth G, Lorbeer R, Reffelmann T, Rettig R, Volker U, Galan P, Gut IG, Hercberg S, Lathrop GM, Zelenika D, Deloukas P, Soranzo N, Williams FM, Zhai G, Salomaa V, Laakso M, Elosua R, Forouhi NG, Volzke H, Uiterwaal CS, van der Schouw YT, Numans ME, Matullo G, Navis G, Berglund G, Bingham SA, Kooner JS, Connell JM, Bandinelli S, Ferrucci L, Watkins H, 
Spector TD, Tuomilehto J, Altshuler D, Strachan DP, Laan M, Meneton P, Wareham NJ, Uda M, Jarvelin MR, Mooser V, Melander O, Loos RJ, Elliott P, Abecasis GR, Caulfield M, Munroe PB. C. Wellcome Trust Case Control. Genome-wide association study identifies eight loci associated with blood pressure. Nature genetics. 2009; 41:666-676. [PubMed: 19430483]

23. Speliotes EK, Willer CJ, Berndt SI, Monda KL, Thorleifsson G, Jackson AU, Lango Allen H, Lindgren CM, Luan J, Magi R, Randall JC, Vedantam S, Winkler TW, Qi L, Workalemahu T, Heid IM, Steinthorsdottir V, Stringham HM, Weedon MN, Wheeler E, Wood AR, Ferreira T, Weyant RJ, Segre AV, Estrada K, Liang L, Nemesh J, Park JH, Gustafsson S, Kilpelainen TO, Yang J, Bouatia-Naji N, Esko T, Feitosa MF, Kutalik Z, Mangino M, Raychaudhuri S, Scherag A, Smith AV, Welch R, Zhao JH, Aben KK, Absher DM, Amin N, Dixon AL, Fisher E, Glazer NL, Goddard ME, Heard-Costa NL, Hoesel V, Hottenga JJ, Johansson A, Johnson T, Ketkar S, Lamina C, Li S, Moffatt MF, Myers RH, Narisu N, Perry JR, Peters MJ, Preuss M, Ripatti S, Rivadeneira F, Sandholt C, Scott LJ, Timpson NJ, Tyrer JP, van Wingerden S, Watanabe RM, White CC, Wiklund F, Barlassina C, Chasman DI, Cooper MN, Jansson JO, Lawrence RW, Pellikka N, Prokopenko I, Shi J, Thiering E, Alavere H, Alibrandi MT, Almgren P, Arnold AM, Aspelund T, Atwood LD, Balkau B, Balmforth AJ, Bennett AJ, Ben-Shlomo Y, Bergman RN, Bergmann S, Biebermann H, Blakemore AI, Boes T, Bonnycastle LL, Bornstein SR, Brown MJ, Buchanan TA, Busonero F, Campbell H, Cappuccio FP, Cavalcanti-Proenca C, Chen YD, Chen CM, Chines PS, Clarke R, Coin L, Connell J, Day IN, den Heijer M, Duan J, Ebrahim S, Elliott P, Elosua R, Eiriksdottir G, Erdos MR, Eriksson JG, Facheris MF, Felix SB, Fischer-Posovszky P, Folsom AR, Friedrich N, Freimer NB, Fu M, Gaget S, Gejman PV, Geus EJ, Gieger C, Gjesing AP, Goel A, Goyette P, Grallert H, Grassler J, Greenawalt DM, Groves CJ, Gudnason V, Guiducci C, Hartikainen AL, Hassanali N, Hall AS, Havulinna AS, Hayward C, Heath AC, Hengstenberg C, Hicks AA, Hinney A, Hofman A, Homuth G, Hui J, Igl W, Iribarren C, Isomaa B, Jacobs KB, Jarick I, Jewell E, John U, Jorgensen T, Jousilahti P, Jula A, Kaakinen M, Kajantie E, Kaplan LM, Kathiresan S, Kettunen J, Kinnunen L, Knowles JW, Kolcic I, Konig IR, Koskinen S, Kovacs P, Kuusisto J, Kraft P, Kvaloy K, Laitinen J, Lantieri O, Lanzani C, Launer LJ, Lecoeur C, Lehtimaki T, Lettre G, Liu J, Lokki ML, Lorentzon M, Luben RN, Ludwig B, Magic, Manunta P, Marek D, Marre M, Martin NG, McArdle WL, McCarthy A, McKnight B, Meitinger T, Melander O, Meyre D, Midthjell K, Montgomery GW, Morken MA, Morris AP, Mulic R, Ngwa JS, Nelis M, Neville MJ, Nyholt DR, O'Donnell CJ, O'Rahilly S, Ong KK, Oostra B, Pare G, Parker AN, Perola M, Pichler I, Pietilainen KH, Platou CG, Polasek O, Pouta A, Rafelt S, Raitakari O, Rayner NW, Ridderstrale M, Rief W, Ruokonen A, Robertson NR, Rzehak P, Salomaa V, Sanders AR, Sandhu MS, Sanna S, Saramies J, Savolainen MJ, Scherag S, Schipf S, Schreiber S, Schunkert H, Silander K, Sinisalo J, Siscovick DS, Smit JH, Soranzo N, Sovio U, Stephens J, Surakka I, Swift AJ, Tammesoo ML, Tardif JC, Teder-Laving M, Teslovich TM, Thompson JR, Thomson B, Tonjes A, Tuomi T, van Meurs JB, van Ommen GJ, Vatin V, Viikari J, Visvikis-Siest S, Vitart V, Vogel CI, Voight BF, Waite LL, Wallaschofski H, Walters GB, Widen E, Wiegand S, Wild SH, Willemsen G, Witte DR, Witteman JC, Xu J, Zhang Q, Zgaga L, Ziegler A, Zitting P, Beilby JP, Farooqi IS, Hebebrand J, Huikuri HV, James AL, Kahonen M, Levinson DF, Macciardi F, Nieminen MS, Ohlsson C, Palmer LJ, Ridker PM, Stumvoll M, Beckmann JS, Boeing H, Boerwinkle E, Boomsma DI, Caulfield MJ, Chanock SJ, Collins FS, Cupples LA, Smith GD, Erdmann J, Froguel P, Gronberg H, Gyllensten U, Hall P, Hansen T, Harris TB, Hattersley AT, Hayes RB, Heinrich J, Hu FB, Hveem K, Illig T, Jarvelin MR, Kaprio J, Karpe F, Khaw KT, Kiemeney LA, Krude H, Laakso M, Lawlor DA, Metspalu A, Munroe PB, Ouwehand WH, Pedersen O, Penninx BW, Peters A, Pramstaller PP, Quertermous T, Reinehr T, Rissanen A, Rudan I, Samani NJ, Schwarz PE, Shuldiner AR, Spector TD, Tuomilehto J, Uda M, Uitterlinden A, Valle TT, Wabitsch M, Waeber G, Wareham NJ, Watkins H, Procardis C, Wilson JF, Wright AF, Zillikens MC, Chatterjee N, McCarroll SA, Purcell S, Schadt EE, Visscher PM, Assimes TL, Borecki IB, Deloukas P, Fox CS, Groop LC, Haritunians T, Hunter DJ, Kaplan RC, Mohlke KL, O'Connell JR, Peltonen L, Schlessinger D, Strachan DP, van Duijn CM, Wichmann HE, Frayling TM, Thorsteinsdottir U, Abecasis GR, Barroso I, Boehnke M, Stefansson K, North KE, McCarthy MI, Hirschhorn JN, Ingelsson E, Loos RJ. Association analyses of 249,796 individuals reveal 18 new loci associated with body mass index. Nature genetics. 2010; 42:937-948. [PubMed: 20935630]

24. Teslovich TM, Musunuru K, Smith AV, Edmondson AC, Stylianou IM, Koseki M, Pirruccello JP, Ripatti S, Chasman DI, Willer CJ, Johansen CT, Fouchier SW, Isaacs A, Peloso GM, Barbalic M, Ricketts SL, Bis JC, Aulchenko YS, Thorleifsson G, Feitosa MF, Chambers J, Orho-Melander M, 
Melander O, Johnson T, Li X, Guo X, Li M, Shin Cho Y, Jin Go M, Jin Kim Y, Lee JY, Park T, Kim K, Sim X, Twee-Hee Ong R, Croteau-Chonka DC, Lange LA, Smith JD, Song K, Hua Zhao J, Yuan X, Luan J, Lamina C, Ziegler A, Zhang W, Zee RY, Wright AF, Witteman JC, Wilson JF, Willemsen G, Wichmann HE, Whitfield JB, Waterworth DM, Wareham NJ, Waeber G, Vollenweider P, Voight BF, Vitart V, Uitterlinden AG, Uda M, Tuomilehto J, Thompson JR, Tanaka T, Surakka I, Stringham HM, Spector TD, Soranzo N, Smit JH, Sinisalo J, Silander K, Sijbrands EJ, Scuteri A, Scott J, Schlessinger D, Sanna S, Salomaa V, Saharinen J, Sabatti C, Ruokonen A, Rudan I, Rose LM, Roberts R, Rieder M, Psaty BM, Pramstaller PP, Pichler I, Perola M, Penninx BW, Pedersen NL, Pattaro C, Parker AN, Pare G, Oostra BA, O'Donnell CJ, Nieminen MS, Nickerson DA, Montgomery GW, Meitinger T, McPherson R, McCarthy MI, McArdle W, Masson D, Martin NG, Marroni F, Mangino M, Magnusson PK, Lucas G, Luben R, Loos RJ, Lokki ML, Lettre G, Langenberg C, Launer LJ, Lakatta EG, Laaksonen R, Kyvik KO, Kronenberg F, Konig IR, Khaw KT, Kaprio J, Kaplan LM, Johansson A, Jarvelin MR, Janssens AC, Ingelsson E, Igl W, Kees Hovingh G, Hottenga JJ, Hofman A, Hicks AA, Hengstenberg C, Heid IM, Hayward C, Havulinna AS, Hastie ND, Harris TB, Haritunians T, Hall AS, Gyllensten U, Guiducci C, Groop LC, Gonzalez E, Gieger C, Freimer NB, Ferrucci L, Erdmann J, Elliott P, Ejebe KG, Doring A, Dominiczak AF, Demissie S, Deloukas P, de Geus EJ, de Faire U, Crawford G, Collins FS, Chen YD, Caulfield MJ, Campbell H, Burtt NP, Bonnycastle LL, Boomsma DI, Boekholdt SM, Bergman RN, Barroso I, Bandinelli S, Ballantyne CM, Assimes TL, Quertermous T, Altshuler D, Seielstad M, Wong TY, Tai ES, Feranil AB, Kuzawa CW, Adair LS, Taylor HA Jr, Borecki IB, Gabriel SB, Wilson JG, Holm H, Thorsteinsdottir U, Gudnason V, Krauss RM, Mohlke KL, Ordovas JM, Munroe PB, Kooner JS, Tall AR, Hegele RA, Kastelein JJ, Schadt EE, Rotter JI, Boerwinkle E, Strachan DP, Mooser V, Stefansson K, Reilly MP, Samani NJ, Schunkert H, Cupples LA, Sandhu MS, Ridker PM, Rader DJ, van Duijn CM, Peltonen L, Abecasis GR, Boehnke M, Kathiresan S. Biological, clinical and population relevance of 95 loci for blood lipids. Nature. 2010; 466:707-713. [PubMed: 20686565]

25. Dehghan A, Dupuis J, Barbalic M, Bis JC, Eiriksdottir G, Lu C, Pellikka N, Wallaschofski H, Kettunen J, Henneman P, Baumert J, Strachan DP, Fuchsberger C, Vitart V, Wilson JF, Pare G, Naitza S, Rudock ME, Surakka I, de Geus EJ, Alizadeh BZ, Guralnik J, Shuldiner A, Tanaka T, Zee RY, Schnabel RB, Nambi V, Kavousi M, Ripatti S, Nauck M, Smith NL, Smith AV, Sundvall J, Scheet P, Liu Y, Ruokonen A, Rose LM, Larson MG, Hoogeveen RC, Freimer NB, Teumer A, Tracy RP, Launer LJ, Buring JE, Yamamoto JF, Folsom AR, Sijbrands EJ, Pankow J, Elliott P, Keaney JF, Sun W, Sarin AP, Fontes JD, Badola S, Astor BC, Hofman A, Pouta A, Werdan K, Greiser KH, Kuss O, Meyer zu Schwabedissen HE, Thiery J, Jamshidi Y, Nolte IM, Soranzo N, Spector TD, Volzke H, Parker AN, Aspelund T, Bates D, Young L, Tsui K, Siscovick DS, Guo X, Rotter JI, Uda M, Schlessinger D, Rudan I, Hicks AA, Penninx BW, Thorand B, Gieger C, Coresh J, Willemsen G, Harris TB, Uitterlinden AG, Jarvelin MR, Rice K, Radke D, Salomaa V, Willems van Dijk K, Boerwinkle E, Vasan RS, Ferrucci L, Gibson QD, Bandinelli S, Snieder H, Boomsma DI, Xiao X, Campbell H, Hayward C, Pramstaller PP, van Duijn CM, Peltonen L, Psaty BM, Gudnason V, Ridker PM, Homuth G, Koenig W, Ballantyne CM, Witteman JC, Benjamin EJ, Perola M, Chasman DI. Meta-analysis of genome-wide association studies in >80 000 subjects identifies multiple loci for C-reactive protein levels. Circulation. 2011; 123:731-738. [PubMed: 21300955]

26. Huang J, Sabater-Lleal M, Asselbergs FW, Tregouet D, Shin SY, Ding J, Baumert J, OudotMellakh T, Folkersen L, Johnson AD, Smith NL, Williams SM, Ikram MA, Kleber ME, Becker DM, Truong V, Mychaleckyj JC, Tang W, Yang Q, Sennblad B, Moore JH, Williams FM, Dehghan A, Silbernagel G, Schrijvers EM, Smith S, Karakas M, Tofler GH, Silveira A, Navis GJ, Lohman K, Chen MH, Peters A, Goel A, Hopewell JC, Chambers JC, Saleheen D, Lundmark P, Psaty BM, Strawbridge RJ, Boehm BO, Carter AM, Meisinger C, Peden JF, Bis JC, McKnight B, Ohrvik J, Taylor K, Franzosi MG, Seedorf U, Collins R, Franco-Cereceda A, Syvanen AC, Goodall AH, Yanek LR, Cushman M, Muller-Nurasyid M, Folsom AR, Basu S, Matijevic N, van Gilst WH, Kooner JS, Hofman A, Danesh J, Clarke R, Meigs JB, Consortium D, Kathiresan S, Reilly MP, Consortium CA, Klopp N, Harris TB, Winkelmann BR, Grant PJ, Hillege HL, Watkins H, Consortium CD, Spector TD, Becker LC, Tracy RP, Marz W, Uitterlinden AG, Eriksson P, Cambien F, Consortium C, Morange PE, Koenig W, Soranzo N, van der Harst P, Liu Y, O'Donnell CJ, Hamsten A. Genome-wide association study for circulating levels of PAI-1 provides novel insights into its regulation. Blood. 2012; 120:4873-4881. [PubMed: 22990020] 
27. Nalls MA, Couper DJ, Tanaka T, van Rooij FJ, Chen MH, Smith AV, Toniolo D, Zakai NA, Yang Q, Greinacher A, Wood AR, Garcia M, Gasparini P, Liu Y, Lumley T, Folsom AR, Reiner AP, Gieger C, Lagou V, Felix JF, Volzke H, Gouskova NA, Biffi A, Doring A, Volker U, Chong S, Wiggins KL, Rendon A, Dehghan A, Moore M, Taylor K, Wilson JG, Lettre G, Hofman A, Bis JC, Pirastu N, Fox CS, Meisinger C, Sambrook J, Arepalli S, Nauck M, Prokisch H, Stephens J, Glazer NL, Cupples LA, Okada Y, Takahashi A, Kamatani Y, Matsuda K, Tsunoda T, Tanaka T, Kubo M, Nakamura Y, Yamamoto K, Kamatani N, Stumvoll M, Tonjes A, Prokopenko I, Illig T, Patel KV, Garner SF, Kuhnel B, Mangino M, Oostra BA, Thein SL, Coresh J, Wichmann HE, Menzel S, Lin J, Pistis G, Uitterlinden AG, Spector TD, Teumer A, Eiriksdottir G, Gudnason V, Bandinelli S, Frayling TM, Chakravarti A, van Duijn CM, Melzer D, Ouwehand WH, Levy D, Boerwinkle E, Singleton AB, Hernandez DG, Longo DL, Soranzo N, Witteman JC, Psaty BM, Ferrucci L, Harris TB, O'Donnell CJ, Ganesh SK. Multiple loci are associated with white blood cell phenotypes. PLoS genetics. 2011; 7:e1002113. [PubMed: 21738480]

28. Pare G, Ridker PM, Rose L, Barbalic M, Dupuis J, Dehghan A, Bis JC, Benjamin EJ, Shiffman D, Parker AN, Chasman DI. Genome-wide association analysis of soluble ICAM-1 concentration reveals novel associations at the NFKBIK, PNPLA3, RELA, and SH2B3 loci. PLoS genetics. 2011; 7:e1001374. [PubMed: 21533024]

29. Richards JB, Waterworth D, O'Rahilly S, Hivert MF, Loos RJ, Perry JR, Tanaka T, Timpson NJ, Semple RK, Soranzo N, Song K, Rocha N, Grundberg E, Dupuis J, Florez JC, Langenberg C, Prokopenko I, Saxena R, Sladek R, Aulchenko Y, Evans D, Waeber G, Erdmann J, Burnett MS, Sattar N, Devaney J, Willenborg C, Hingorani A, Witteman JC, Vollenweider P, Glaser B, Hengstenberg C, Ferrucci L, Melzer D, Stark K, Deanfield J, Winogradow J, Grassl M, Hall AS, Egan JM, Thompson JR, Ricketts SL, Konig IR, Reinhard W, Grundy S, Wichmann HE, Barter P, Mahley R, Kesaniemi YA, Rader DJ, Reilly MP, Epstein SE, Stewart AF, Van Duijn CM, Schunkert H, Burling K, Deloukas P, Pastinen T, Samani NJ, McPherson R, Davey Smith G, Frayling TM, Wareham NJ, Meigs JB, Mooser V, Spector TD, Consortium G. A genome-wide association study reveals variants in ARL15 that influence adiponectin levels. PLoS genetics. 2009; 5:e1000768. [PubMed: 20011104]

30. Dallmeier D, Larson MG, Vasan RS, Keaney JF Jr, Fontes JD, Meigs JB, Fox CS, Benjamin EJ. Metabolic syndrome and inflammatory biomarkers: a community-based cross-sectional study at the Framingham Heart Study. Diabetology \& metabolic syndrome. 2012; 4:28. [PubMed: 22716219]

31. Province MA, Kardia SL, Ranade K, Rao DC, Thiel BA, Cooper RS, Risch N, Turner ST, Cox DR, Hunt SC, Weder AB, Boerwinkle E. A meta-analysis of genome-wide linkage scans for hypertension: the National Heart, Lung and Blood Institute Family Blood Pressure Program. Am J Hypertens. 2003; 16:144-147. [PubMed: 12559682]

32. Borecki IB, Province MA. Genetic and genomic discovery using family studies. Circulation. 2008; 118:1057-1063. [PubMed: 18765388]

33. Willer CJ, Speliotes EK, Loos RJ, Li S, Lindgren CM, Heid IM, Berndt SI, Elliott AL, Jackson AU, Lamina C, Lettre G, Lim N, Lyon HN, McCarroll SA, Papadakis K, Qi L, Randall JC, Roccasecca RM, Sanna S, Scheet P, Weedon MN, Wheeler E, Zhao JH, Jacobs LC, Prokopenko I, Soranzo N, Tanaka T, Timpson NJ, Almgren P, Bennett A, Bergman RN, Bingham SA, Bonnycastle LL, Brown M, Burtt NP, Chines P, Coin L, Collins FS, Connell JM, Cooper C, Smith GD, Dennison EM, Deodhar P, Elliott P, Erdos MR, Estrada K, Evans DM, Gianniny L, Gieger C, Gillson CJ, Guiducci C, Hackett R, Hadley D, Hall AS, Havulinna AS, Hebebrand J, Hofman A, Isomaa B, Jacobs KB, Johnson T, Jousilahti P, Jovanovic Z, Khaw KT, Kraft P, Kuokkanen M, Kuusisto J, Laitinen J, Lakatta EG, Luan J, Luben RN, Mangino M, McArdle WL, Meitinger T, Mulas A, Munroe PB, Narisu N, Ness AR, Northstone K, O'Rahilly S, Purmann C, Rees MG, Ridderstrale M, Ring SM, Rivadeneira F, Ruokonen A, Sandhu MS, Saramies J, Scott LJ, Scuteri A, Silander K, Sims MA, Song K, Stephens J, Stevens S, Stringham HM, Tung YC, Valle TT, Van Duijn CM, Vimaleswaran KS, Vollenweider P, Waeber G, Wallace C, Watanabe RM, Waterworth DM, Watkins N, Witteman JC, Zeggini E, Zhai G, Zillikens MC, Altshuler D, Caulfield MJ, Chanock SJ, Farooqi IS, Ferrucci L, Guralnik JM, Hattersley AT, Hu FB, Jarvelin MR, Laakso M, Mooser V, Ong KK, Ouwehand WH, Salomaa V, Samani NJ, Spector TD, Tuomi T, Tuomilehto J, Uda M, Uitterlinden AG, Wareham NJ, Deloukas P, Frayling TM, Groop LC, Hayes RB, Hunter DJ, Mohlke KL, Peltonen L, Schlessinger D, Strachan DP, Wichmann HE, McCarthy MI, 
Boehnke M, Barroso I, Abecasis GR, Hirschhorn JN. C. Wellcome Trust Case Control. A.T.C. Genetic Investigation of, Six new loci associated with body mass index highlight a neuronal influence on body weight regulation. Nature genetics. 2009; 41:25-34. [PubMed: 19079261]

34. Dastani Z, Hivert MF, Timpson N, Perry JR, Yuan X, Scott RA, Henneman P, Heid IM, Kizer JR, Lyytikainen LP, Fuchsberger C, Tanaka T, Morris AP, Small K, Isaacs A, Beekman M, Coassin S, Lohman K, Qi L, Kanoni S, Pankow JS, Uh HW, Wu Y, Bidulescu A, Rasmussen-Torvik LJ, Greenwood CM, Ladouceur M, Grimsby J, Manning AK, Liu CT, Kooner J, Mooser VE, Vollenweider P, Kapur KA, Chambers J, Wareham NJ, Langenberg C, Frants R, Willems-Vandijk K, Oostra BA, Willems SM, Lamina C, Winkler TW, Psaty BM, Tracy RP, Brody J, Chen I, Viikari J, Kahonen M, Pramstaller PP, Evans DM, St Pourcain B, Sattar N, Wood AR, Bandinelli S, Carlson OD, Egan JM, Bohringer S, van Heemst D, Kedenko L, Kristiansson K, Nuotio ML, Loo BM, Harris T, Garcia M, Kanaya A, Haun M, Klopp N, Wichmann HE, Deloukas P, Katsareli E, Couper DJ, Duncan BB, Kloppenburg M, Adair LS, Borja JB, Consortium D, Consortium M, Investigators G, Mu TC, Wilson JG, Musani S, Guo X, Johnson T, Semple R, Teslovich TM, Allison MA, Redline S, Buxbaum SG, Mohlke KL, Meulenbelt I, Ballantyne CM, Dedoussis GV, Hu FB, Liu Y, Paulweber B, Spector TD, Slagboom PE, Ferrucci L, Jula A, Perola M, Raitakari O, Florez JC, Salomaa V, Eriksson JG, Frayling TM, Hicks AA, Lehtimaki T, Smith GD, Siscovick DS, Kronenberg F, van Duijn C, Loos RJ, Waterworth DM, Meigs JB, Dupuis J, Richards JB, Voight BF, Scott LJ, Steinthorsdottir V, Dina C, Welch RP, Zeggini E, Huth C, Aulchenko YS, Thorleifsson G, McCulloch LJ, Ferreira T, Grallert H, Amin N, Wu G, Willer CJ, Raychaudhuri S, McCarroll SA, Hofmann OM, Segre AV, van Hoek M, Navarro P, Ardlie K, Balkau B, Benediktsson R, Bennett AJ, Blagieva R, Boerwinkle E, Bonnycastle LL, Bostrom KB, Bravenboer B, Bumpstead S, Burtt NP, Charpentier G, Chines PS, Cornelis M, Crawford G, Doney AS, Elliott KS, Elliott AL, Erdos MR, Fox CS, Franklin CS, Ganser M, Gieger C, Grarup N, Green T, Griffin S, Groves CJ, Guiducci C, Hadjadj S, Hassanali N, Herder C, Isomaa B, Jackson AU, Johnson PR, Jorgensen T, Kao WH, Kong A, Kraft P, Kuusisto J, Lauritzen T, Li M, Lieverse A, Lindgren CM, Lyssenko V, Marre M, Meitinger T, Midthjell K, Morken MA, Narisu N, Nilsson P, Owen KR, Payne F, Petersen AK, Platou C, Proenca C, Prokopenko I, Rathmann W, Rayner NW, Robertson NR, Rocheleau G, Roden M, Sampson MJ, Saxena R, Shields BM, Shrader P, Sigurdsson G, Sparso T, Strassburger K, Stringham HM, Sun Q, Swift AJ, Thorand B, Tichet J, Tuomi T, van Dam RM, van Haeften TW, van Herpt T, van Vliet-Ostaptchouk JV, Walters GB, Weedon MN, Wijmenga C, Witteman J, Bergman RN, Cauchi S, Collins FS, Gloyn AL, Gyllensten U, Hansen T, Hide WA, Hitman GA, Hofman A, Hunter DJ, Hveem K, Laakso M, Morris AD, Palmer CN, Rudan I, Sijbrands E, Stein LD, Tuomilehto J, Uitterlinden A, Walker M, Watanabe RM, Abecasis GR, Boehm BO, Campbell H, Daly MJ, Hattersley AT, Pedersen O, Barroso I, Groop L, Sladek R, Thorsteinsdottir U, Wilson JF, Illig T, Froguel P, van Duijn CM, Stefansson K, Altshuler D, Boehnke M, McCarthy MI, Soranzo N, Wheeler E, Glazer NL, Bouatia-Naji N, Magi R, Randall J, Elliott P, Rybin D, Dehghan A, Hottenga JJ, Song K, Goel A, Lajunen T, Doney A, Cavalcanti-Proenca C, Kumari M, Timpson NJ, Zabena C, Ingelsson E, An P, O'Connell J, Luan J, Elliott A, McCarroll SA, Roccasecca RM, Pattou F, Sethupathy P, Ariyurek Y, Barter P, Beilby JP, Ben-Shlomo Y, Bergmann S, Bochud M, Bonnefond A, BorchJohnsen K, Bottcher Y, Brunner E, Bumpstead SJ, Chen YD, Chines P, Clarke R, Coin LJ, Cooper MN, Crisponi L, Day IN, de Geus EJ, Delplanque J, Fedson AC, Fischer-Rosinsky A, Forouhi NG, Franzosi MG, Galan P, Goodarzi MO, Graessler J, Grundy S, Gwilliam R, Hallmans G, Hammond N, Han X, Hartikainen AL, Hayward C, Heath SC, Hercberg S, Hillman DR, Hingorani AD, Hui J, Hung J, Kaakinen M, Kaprio J, Kesaniemi YA, Kivimaki M, Knight B, Koskinen S, Kovacs P, Kyvik KO, Lathrop GM, Lawlor DA, Le Bacquer O, Lecoeur C, Li Y, Mahley R, Mangino M, Martinez-Larrad MT, McAteer JB, McPherson R, Meisinger C, Melzer D, Meyre D, Mitchell BD, Mukherjee S, Naitza S, Neville MJ, Orru M, Pakyz R, Paolisso G, Pattaro C, Pearson D, Peden JF, Pedersen NL, Pfeiffer AF, Pichler I, Polasek O, Posthuma D, Potter SC, Pouta A, Province MA, Rayner NW, Rice K, Ripatti S, Rivadeneira F, Rolandsson O, Sandbaek A, Sandhu M, Sanna S, Sayer AA, Scheet P, Seedorf U, Sharp SJ, Shields B, Sigurethsson G, Sijbrands EJ, Silveira A, Simpson L, Singleton A, Smith NL, Sovio U, Swift A, Syddall H, Syvanen AC, Tonjes A, Uitterlinden AG, van Dijk KW, Varma D, Visvikis-Siest S, Vitart V, Vogelzangs N, Waeber G, Wagner PJ, Walley A, Ward KL, Watkins H, Wild SH, Willemsen G, Witteman JC, Yarnell JW, Zelenika D, Zethelius B, Zhai G, Zhao JH, Zillikens MC, Consortium D, Consortium G, Global BPC, Borecki IB, Meneton P, Magnusson PK, Nathan DM, Williams GH, Silander K, Bornstein 
SR, Schwarz P, Spranger J, Karpe F, Shuldiner AR, Cooper C, Serrano-Rios M, Lind L, Palmer LJ, Hu FBs, Franks PW, Ebrahim S, Marmot M, Kao WH, Pramstaller PP, Wright AF, Stumvoll M, Hamsten A, Procardis C, Buchanan TA, Valle TT, Rotter JI, Penninx BW, Boomsma DI, Cao A, Scuteri A, Schlessinger D, Uda M, Ruokonen A, Jarvelin MR, Peltonen L, Mooser V, Sladek R, Musunuru K, Smith AV, Edmondson AC, Stylianou IM, Koseki M, Pirruccello JP, Chasman DI, Johansen CT, Fouchier SW, Peloso GM, Barbalic M, Ricketts SL, Bis JC, Feitosa MF, OrhoMelander M, Melander O, Li X, Li M, Cho YS, Go MJ, Kim YJ, Lee JY, Park T, Kim K, Sim X, Ong RT, Croteau-Chonka DC, Lange LA, Smith JD, Ziegler A, Zhang W, Zee RY, Whitfield JB, Thompson JR, Surakka I, Spector TD, Smit JH, Sinisalo J, Scott J, Saharinen J, Sabatti C, Rose LM, Roberts R, Rieder M, Parker AN, Pare G, O'Donnell CJ, Nieminen MS, Nickerson DA, Montgomery GW, McArdle W, Masson D, Martin NG, Marroni F, Lucas G, Luben R, Lokki ML, Lettre G, Launer LJ, Lakatta EG, Laaksonen R, Kyvik KO, Konig IR, Khaw KT, Kaplan LM, Johansson A, Janssens AC, Igl W, Hovingh GK, Hengstenberg C, Havulinna AS, Hastie ND, Harris TB, Haritunians T, Hall AS, Groop LC, Gonzalez E, Freimer NB, Erdmann J, Ejebe KG, Doring A, Dominiczak AF, Demissie S, Deloukas P, de Faire U, Crawford G, Chen YD, Caulfield MJ, Boekholdt SM, Assimes TL, Quertermous T, Seielstad M, Wong TY, Tai ES, Feranil AB, Kuzawa CW, Taylor HA Jr, Gabriel SB, Holm H, Gudnason V, Krauss RM, Ordovas JM, Munroe PB, Kooner JS, Tall AR, Hegele RA, Kastelein JJ, Schadt EE, Strachan DP, Reilly MP, Samani NJ, Schunkert H, Cupples LA, Sandhu MS, Ridker PM, Rader DJ, Kathiresan S. M. investigators, G. Consortium. Novel loci for adiponectin levels and their influence on type 2 diabetes and metabolic traits: a multi-ethnic meta-analysis of 45,891 individuals. PLoS genetics. 2012; 8:e1002607. [PubMed: 22479202]

35. Tekola Ayele F, Doumatey A, Huang H, Zhou J, Charles B, Erdos M, Adeleye J, Balogun W, Fasanmade O, Johnson T, Oli J, Okafor G, Amoah A, Eghan BA Jr, Agyenim-Boateng K, Acheampong J, Adebamowo CA, Herbert A, Gerry N, Christman M, Chen G, Shriner D, Adeyemo A, Rotimi CN. Genome-wide associated loci influencing interleukin (IL)-10, IL-1Ra, and IL-6 levels in African Americans. Immunogenetics. 2012; 64:351-359. [PubMed: 22205395]

36. Grundy SM, Brewer HB Jr, Cleeman JI, Smith SC Jr, Lenfant C. A. American Heart, L. National Heart, I. Blood, Definition of metabolic syndrome: Report of the National Heart, Lung, and Blood Institute/American Heart Association conference on scientific issues related to definition. Circulation. 2004; 109:433-438. [PubMed: 14744958]

37. Wu J, Kraja AT, Oberman A, Lewis CE, Ellison RC, Arnett DK, Heiss G, Lalouel JM, Turner ST, Hunt SC, Province MA, Rao DC. A summary of the effects of antihypertensive medications on measured blood pressure. Am J Hypertens. 2005; 18:935-942. [PubMed: 16053990]

38. Wu J, Province MA, Coon H, Hunt SC, Eckfeldt JH, Arnett DK, Heiss G, Lewis CE, Ellison RC, Rao DC, Rice T, Kraja AT. An investigation of the effects of lipid-lowering medications: genomewide linkage analysis of lipids in the HyperGEN study. BMC genetics. 2007; 8:60. [PubMed: 17845730]

39. Ripley, BD. Stochastic simulation. New York; Chichester: Wiley; 1987.

40. Cureton, EE.; D'Agostino, RB. Factor analysis, an applied approach. Hillsdale, N.J.: L. Erlbaum Associates; 1983.

41. Lande R. The Genetic Covariance between Characters Maintained by Pleiotropic Mutations. Genetics. 1980; 94:203-215. [PubMed: 17248993]

42. Johnson AD, O'Donnell CJ. An open access database of genome-wide association results. BMC medical genetics. 2009; 10:6. [PubMed: 19161620]

43. Sivakumaran S, Agakov F, Theodoratou E, Prendergast JG, Zgaga L, Manolio T, Rudan I, McKeigue P, Wilson JF, Campbell H. Abundant pleiotropy in human complex diseases and traits. American journal of human genetics. 2011; 89:607-618. [PubMed: 22077970]

44. Almasy L, Dyer TD, Blangero J. Bivariate quantitative trait linkage analysis: pleiotropy versus coincident linkages. Genet Epidemiol. 1997; 14:953-958. [PubMed: 9433606]

45. Huang J, Johnson AD, O'Donnell CJ. PRIMe: a method for characterization and evaluation of pleiotropic regions from multiple genome-wide association studies. Bioinformatics. 2011; 27:1201-1206. [PubMed: 21398673]

46. Pearson, K. On the theory of contingency and its relation to association and normal correlation. London: 1904. 
47. Fisher, RA. Statistical Methods for Research Workers, Thirteenth edition. London, England: Oliver and Loyd, Ltd.; 1925.

48. Province MA. The significance of not finding a gene. American journal of human genetics. 2001; 69:660-663. [PubMed: 11481587]

49. Hindorff LA, Sethupathy P, Junkins HA, Ramos EM, Mehta JP, Collins FS, Manolio TA. Potential etiologic and functional implications of genome-wide association loci for human diseases and traits. Proceedings of the National Academy of Sciences of the United States of America. 2009; 106:9362-9367. [PubMed: 19474294]

50. Ernst J, Kheradpour P, Mikkelsen TS, Shoresh N, Ward LD, Epstein CB, Zhang X, Wang L, Issner R, Coyne M, Ku M, Durham T, Kellis M, Bernstein BE. Mapping and analysis of chromatin state dynamics in nine human cell types. Nature. 2011; 473:43-49. [PubMed: 21441907]

51. Boyle AP, Hong EL, Hariharan M, Cheng Y, Schaub MA, Kasowski M, Karczewski KJ, Park J, Hitz BC, Weng S, Cherry JM, Snyder M. Annotation of functional variation in personal genomes using RegulomeDB. Genome research. 2012; 22:1790-1797. [PubMed: 22955989]

52. Kodama A, Karakesisoglou I, Wong E, Vaezi A, Fuchs E. ACF7: an essential integrator of microtubule dynamics. Cell. 2003; 115:343-354. [PubMed: 14636561]

53. Lin CM, Chen HJ, Leung CL, Parry DA, Liem RK. Microtubule actin crosslinking factor 1b: a novel plakin that localizes to the Golgi complex. Journal of cell science. 2005; 118:3727-3738. [PubMed: 16076900]

54. Ehret GB, Munroe PB, Rice KM, Bochud M, Johnson AD, Chasman DI, Smith AV, Tobin MD, Verwoert GC, Hwang SJ, Pihur V, Vollenweider P, O'Reilly PF, Amin N, Bragg-Gresham JL, Teumer A, Glazer NL, Launer L, Zhao JH, Aulchenko Y, Heath S, Sober S, Parsa A, Luan J, Arora P, Dehghan A, Zhang F, Lucas G, Hicks AA, Jackson AU, Peden JF, Tanaka T, Wild SH, Rudan I, Igl W, Milaneschi Y, Parker AN, Fava C, Chambers JC, Fox ER, Kumari M, Go MJ, van der Harst P, Kao WH, Sjogren M, Vinay DG, Alexander M, Tabara Y, Shaw-Hawkins S, Whincup PH, Liu Y, Shi G, Kuusisto J, Tayo B, Seielstad M, Sim X, Nguyen KD, Lehtimaki T, Matullo G, Wu Y, Gaunt TR, Onland-Moret NC, Cooper MN, Platou CG, Org E, Hardy R, Dahgam S, Palmen J, Vitart V, Braund PS, Kuznetsova T, Uiterwaal CS, Adeyemo A, Palmas W, Campbell H, Ludwig B, Tomaszewski M, Tzoulaki I, Palmer ND, consortium CA, Consortium CK, KidneyGen C, EchoGen c, consortium C-H, Aspelund T, Garcia M, Chang YP, O'Connell JR, Steinle NI, Grobbee DE, Arking DE, Kardia SL, Morrison AC, Hernandez D, Najjar S, McArdle WL, Hadley D, Brown MJ, Connell JM, Hingorani AD, Day IN, Lawlor DA, Beilby JP, Lawrence RW, Clarke R, Hopewell JC, Ongen H, Dreisbach AW, Li Y, Young JH, Bis JC, Kahonen M, Viikari J, Adair LS, Lee NR, Chen MH, Olden M, Pattaro C, Bolton JA, Kottgen A, Bergmann S, Mooser V, Chaturvedi N, Frayling TM, Islam M, Jafar TH, Erdmann J, Kulkarni SR, Bornstein SR, Grassler J, Groop L, Voight BF, Kettunen J, Howard P, Taylor A, Guarrera S, Ricceri F, Emilsson V, Plump A, Barroso I, Khaw KT, Weder AB, Hunt SC, Sun YV, Bergman RN, Collins FS, Bonnycastle LL, Scott LJ, Stringham HM, Peltonen L, Perola M, Vartiainen E, Brand SM, Staessen JA, Wang TJ, Burton PR, Soler Artigas M, Dong Y, Snieder H, Wang X, Zhu H, Lohman KK, Rudock ME, Heckbert SR, Smith NL, Wiggins KL, Doumatey A, Shriner D, Veldre G, Viigimaa M, Kinra S, Prabhakaran D, Tripathy V, Langefeld CD, Rosengren A, Thelle DS, Corsi AM, Singleton A, Forrester T, Hilton G, McKenzie CA, Salako T, Iwai N, Kita Y, Ogihara T, Ohkubo T, Okamura T, Ueshima H, Umemura S, Eyheramendy S, Meitinger T, Wichmann HE, Cho YS, Kim HL, Lee JY, Scott J, Sehmi JS, Zhang W, Hedblad B, Nilsson P, Smith GD, Wong A, Narisu N, Stancakova A, Raffel LJ, Yao J, Kathiresan S, O'Donnell CJ, Schwartz SM, Ikram MA, Longstreth WT Jr, Mosley TH, Seshadri S, Shrine NR, Wain LV, Morken MA, Swift AJ, Laitinen J, Prokopenko I, Zitting P, Cooper JA, Humphries SE, Danesh J, Rasheed A, Goel A, Hamsten A, Watkins H, Bakker SJ, van Gilst WH, Janipalli CS, Mani KR, Yajnik CS, Hofman A, Mattace-Raso FU, Oostra BA, Demirkan A, Isaacs A, Rivadeneira F, Lakatta EG, Orru M, Scuteri A, Ala-Korpela M, Kangas AJ, Lyytikainen LP, Soininen P, Tukiainen T, Wurtz P, Ong RT, Dorr M, Kroemer HK, Volker U, Volzke H, Galan P, Hercberg S, Lathrop M, Zelenika D, Deloukas P, Mangino M, Spector TD, Zhai G, Meschia JF, Nalls MA, Sharma P, Terzic J, Kumar MV, Denniff M, Zukowska-Szczechowska E, Wagenknecht LE, Fowkes FG, Charchar FJ, Schwarz PE, Hayward C, Guo X, Rotimi C, Bots ML, Brand E, Samani NJ, Polasek O, Talmud PJ, Nyberg F, Kuh D, Laan M, Hveem K, Palmer LJ, van der Schouw YT, Casas JP, Mohlke KL, Vineis P, Raitakari O, Ganesh SK, Wong TY, Tai ES, Cooper RS, Laakso M, Rao DC, Harris TB, Morris 
RW, Dominiczak AF, Kivimaki M, Marmot MG, Miki T, Saleheen D, Chandak GR, Coresh J, Navis G, Salomaa V, Han BG, Zhu X, Kooner JS, Melander O, Ridker PM, Bandinelli S, Gyllensten UB, Wright AF, Wilson JF, Ferrucci L, Farrall M, Tuomilehto J, Pramstaller PP, Elosua R, Soranzo N, Sijbrands EJ, Altshuler D, Loos RJ, Shuldiner AR, Gieger C, Meneton P, Uitterlinden AG, Wareham NJ, Gudnason V, Rotter JI, Rettig R, Uda M, Strachan DP, Witteman JC, Hartikainen AL, Beckmann JS, Boerwinkle E, Vasan RS, Boehnke M, Larson MG, Jarvelin MR, Psaty BM, Abecasis GR, Chakravarti A, Elliott P, van Duijn CM, Newton-Cheh C, Levy D, Caulfield MJ, Johnson T. S. International Consortium for Blood Pressure Genome-Wide Association. Genetic variants in novel pathways influence blood pressure and cardiovascular disease risk. Nature. 2011; 478:103-109. [PubMed: 21909115]

55. Febbo PG, Mulligan MG, Slonina DA, Stegmaier K, Di Vizio D, Martinez PR, Loda M, Taylor SC. Literature Lab: a method of automated literature interrogation to infer biology from microarray analysis. BMC genomics. 2007; 8:461. [PubMed: 18088408]

56. Waterworth DM, Ricketts SL, Song K, Chen L, Zhao JH, Ripatti S, Aulchenko YS, Zhang W, Yuan X, Lim N, Luan J, Ashford S, Wheeler E, Young EH, Hadley D, Thompson JR, Braund PS, Johnson T, Struchalin M, Surakka I, Luben R, Khaw KT, Rodwell SA, Loos RJ, Boekholdt SM, Inouye M, Deloukas P, Elliott P, Schlessinger D, Sanna S, Scuteri A, Jackson A, Mohlke KL, Tuomilehto J, Roberts R, Stewart A, Kesaniemi YA, Mahley RW, Grundy SM, McArdle W, Cardon L, Waeber G, Vollenweider P, Chambers JC, Boehnke M, Abecasis GR, Salomaa V, Jarvelin MR, Ruokonen A, Barroso I, Epstein SE, Hakonarson HH, Rader DJ, Reilly MP, Witteman JC, Hall AS, Samani NJ, Strachan DP, Barter P, van Duijn CM, Kooner JS, Peltonen L, Wareham NJ, McPherson R, Mooser V, Sandhu MS. C. Wellcome Trust Case Control. Genetic variants influencing circulating lipid levels and risk of coronary artery disease. Arteriosclerosis, thrombosis, and vascular biology. 2010; 30:2264-2276.

57. Tang W, Basu S, Kong X, Pankow JS, Aleksic N, Tan A, Cushman M, Boerwinkle E, Folsom AR. Genome-wide association study identifies novel loci for plasma levels of protein C: the ARIC study. Blood. 2010; 116:5032-5036. [PubMed: 20802025]

58. Kottgen A, Albrecht E, Teumer A, Vitart V, Krumsiek J, Hundertmark C, Pistis G, Ruggiero D, O'Seaghdha CM, Haller T, Yang Q, Tanaka T, Johnson AD, Kutalik Z, Smith AV, Shi J, Struchalin M, Middelberg RP, Brown MJ, Gaffo AL, Pirastu N, Li G, Hayward C, Zemunik T, Huffman J, Yengo L, Zhao JH, Demirkan A, Feitosa MF, Liu X, Malerba G, Lopez LM, van der Harst P, Li X, Kleber ME, Hicks AA, Nolte IM, Johansson A, Murgia F, Wild SH, Bakker SJ, Peden JF, Dehghan A, Steri M, Tenesa A, Lagou V, Salo P, Mangino M, Rose LM, Lehtimaki T, Woodward OM, Okada Y, Tin A, Muller C, Oldmeadow C, Putku M, Czamara D, Kraft P, Frogheri L, Thun GA, Grotevendt A, Gislason GK, Harris TB, Launer LJ, McArdle P, Shuldiner AR, Boerwinkle E, Coresh J, Schmidt H, Schallert M, Martin NG, Montgomery GW, Kubo M, Nakamura Y, Tanaka T, Munroe PB, Samani NJ, Jacobs DR Jr, Liu K, D'Adamo P, Ulivi S, Rotter JI, Psaty BM, Vollenweider P, Waeber G, Campbell S, Devuyst O, Navarro P, Kolcic I, Hastie N, Balkau B, Froguel P, Esko T, Salumets A, Khaw KT, Langenberg C, Wareham NJ, Isaacs A, Kraja A, Zhang Q, Wild PS, Scott RJ, Holliday EG, Org E, Viigimaa M, Bandinelli S, Metter JE, Lupo A, Trabetti E, Sorice R, Doring A, Lattka E, Strauch K, Theis F, Waldenberger M, Wichmann HE, Davies G, Gow AJ, Bruinenberg M, LifeLines Cohort S, Stolk RP, Kooner JS, Zhang W, Winkelmann BR, Boehm BO, Lucae S, Penninx BW, Smit JH, Curhan G, Mudgal P, Plenge RM, Portas L, Persico I, Kirin M, Wilson JF, Mateo Leach I, van Gilst WH, Goel A, Ongen H, Hofman A, Rivadeneira F, Uitterlinden AG, Imboden M, von Eckardstein A, Cucca F, Nagaraja R, Piras MG, Nauck M, Schurmann C, Budde K, Ernst F, Farrington SM, Theodoratou E, Prokopenko I, Stumvoll M, Jula A, Perola M, Salomaa V, Shin SY, Spector TD, Sala C, Ridker PM, Kahonen M, Viikari J, Hengstenberg C, Nelson CP, Consortium CA, Consortium D, Consortium I, Consortium M, Meschia JF, Nalls MA, Sharma P, Singleton AB, Kamatani N, Zeller T, Burnier M, Attia J, Laan M, Klopp N, Hillege HL, Kloiber S, Choi H, Pirastu M, Tore S, Probst-Hensch NM, Volzke H, Gudnason V, Parsa A, Schmidt R, Whitfield JB, Fornage M, Gasparini P, Siscovick DS, Polasek O, Campbell H, Rudan I, Bouatia-Naji N, Metspalu A, Loos RJ, van Duijn CM, Borecki IB, Ferrucci L, Gambaro G, Deary IJ, Wolffenbuttel BH, Chambers JC, Marz W, Pramstaller PP, Snieder H, Gyllensten U, Wright AF, Navis G, Watkins H, Witteman JC, Sanna S, Schipf S, Dunlop MG, Tonjes A, Ripatti S, Soranzo N, Toniolo D, Chasman DI, Raitakari O, Kao WH, Ciullo M, Fox CS, Caulfield M, Bochud M, Gieger C. Genome-wide 
association analyses identify 18 new loci associated with serum urate concentrations. Nature genetics. 2013; 45:145-154. [PubMed: 23263486]

59. Kim YJ, Go MJ, Hu C, Hong CB, Kim YK, Lee JY, Hwang JY, Oh JH, Kim DJ, Kim NH, Kim S, Hong EJ, Kim JH, Min H, Kim Y, Zhang R, Jia W, Okada Y, Takahashi A, Kubo M, Tanaka T, Kamatani N, Matsuda K, consortium M, Park T, Oh B, Kimm K, Kang D, Shin C, Cho NH, Kim HL, Han BG, Lee JY, Cho YS. Large-scale genome-wide association studies in East Asians identify new genetic loci influencing metabolic traits. Nature genetics. 2011; 43:990-995. [PubMed: 21909109]

60. Kathiresan S, Melander O, Guiducci C, Surti A, Burtt NP, Rieder MJ, Cooper GM, Roos C, Voight BF, Havulinna AS, Wahlstrand B, Hedner T, Corella D, Tai ES, Ordovas JM, Berglund G, Vartiainen E, Jousilahti P, Hedblad B, Taskinen MR, Newton-Cheh C, Salomaa V, Peltonen L, Groop L, Altshuler DM, Orho-Melander M. Six new loci associated with blood low-density lipoprotein cholesterol, high-density lipoprotein cholesterol or triglycerides in humans. Nature genetics. 2008; 40:189-197. [PubMed: 18193044]

61. Willer CJ, Sanna S, Jackson AU, Scuteri A, Bonnycastle LL, Clarke R, Heath SC, Timpson NJ, Najjar SS, Stringham HM, Strait J, Duren WL, Maschio A, Busonero F, Mulas A, Albai G, Swift AJ, Morken MA, Narisu N, Bennett D, Parish S, Shen H, Galan P, Meneton P, Hercberg S, Zelenika D, Chen WM, Li Y, Scott LJ, Scheet PA, Sundvall J, Watanabe RM, Nagaraja R, Ebrahim S, Lawlor DA, Ben-Shlomo Y, Davey-Smith G, Shuldiner AR, Collins R, Bergman RN, Uda M, Tuomilehto J, Cao A, Collins FS, Lakatta E, Lathrop GM, Boehnke M, Schlessinger D, Mohlke KL, Abecasis GR. Newly identified loci that influence lipid concentrations and risk of coronary artery disease. Nature genetics. 2008; 40:161-169. [PubMed: 18193043]

62. Kettunen J, Tukiainen T, Sarin AP, Ortega-Alonso A, Tikkanen E, Lyytikainen LP, Kangas AJ, Soininen P, Wurtz P, Silander K, Dick DM, Rose RJ, Savolainen MJ, Viikari J, Kahonen M, Lehtimaki T, Pietilainen KH, Inouye M, McCarthy MI, Jula A, Eriksson J, Raitakari OT, Salomaa V, Kaprio J, Jarvelin MR, Peltonen L, Perola M, Freimer NB, Ala-Korpela M, Palotie A, Ripatti S. Genome-wide association study identifies multiple loci influencing human serum metabolite levels. Nature genetics. 2012; 44:269-276. [PubMed: 22286219]

63. Kristiansson K, Perola M, Tikkanen E, Kettunen J, Surakka I, Havulinna AS, Stancakova A, Barnes C, Widen E, Kajantie E, Eriksson JG, Viikari J, Kahonen M, Lehtimaki T, Raitakari OT, Hartikainen AL, Ruokonen A, Pouta A, Jula A, Kangas AJ, Soininen P, Ala-Korpela M, Mannisto S, Jousilahti P, Bonnycastle LL, Jarvelin MR, Kuusisto J, Collins FS, Laakso M, Hurles ME, Palotie A, Peltonen L, Ripatti S, Salomaa V. Genome-wide screen for metabolic syndrome susceptibility Loci reveals strong lipid gene contribution but no evidence for common genetic basis for clustering of metabolic syndrome traits Circulation. Cardiovascular genetics. 2012; 5:242-249. [PubMed: 22399527]

64. Kooner JS, Chambers JC, Aguilar-Salinas CA, Hinds DA, Hyde CL, Warnes GR, Gomez Perez FJ, Frazer KA, Elliott P, Scott J, Milos PM, Cox DR, Thompson JF. Genome-wide scan identifies variation in MLXIPL associated with plasma triglycerides. Nature genetics. 2008; 40:149-151. [PubMed: 18193046]

65. Chambers JC, Zhang W, Sehmi J, Li X, Wass MN, Van der Harst P, Holm H, Sanna S, Kavousi M, Baumeister SE, Coin LJ, Deng G, Gieger C, Heard-Costa NL, Hottenga JJ, Kuhnel B, Kumar V, Lagou V, Liang L, Luan J, Vidal PM, Mateo Leach I, O'Reilly PF, Peden JF, Rahmioglu N, Soininen P, Speliotes EK, Yuan X, Thorleifsson G, Alizadeh BZ, Atwood LD, Borecki IB, Brown MJ, Charoen P, Cucca F, Das D, de Geus EJ, Dixon AL, Doring A, Ehret G, Eyjolfsson GI, Farrall M, Forouhi NG, Friedrich N, Goessling W, Gudbjartsson DF, Harris TB, Hartikainen AL, Heath S, Hirschfield GM, Hofman A, Homuth G, Hypponen E, Janssen HL, Johnson T, Kangas AJ, Kema IP, Kuhn JP, Lai S, Lathrop M, Lerch MM, Li Y, Liang TJ, Lin JP, Loos RJ, Martin NG, Moffatt MF, Montgomery GW, Munroe PB, Musunuru K, Nakamura Y, O'Donnell CJ, Olafsson I, Penninx BW, Pouta A, Prins BP, Prokopenko I, Puls R, Ruokonen A, Savolainen MJ, Schlessinger D, Schouten JN, Seedorf U, Sen-Chowdhry S, Siminovitch KA, Smit JH, Spector TD, Tan W, Teslovich TM, Tukiainen T, Uitterlinden AG, Van der Klauw MM, Vasan RS, Wallace C, Wallaschofski H, Wichmann HE, Willemsen G, Wurtz P, Xu C, Yerges-Armstrong LM, Abecasis GR, Ahmadi KR, Boomsma DI, Caulfield M, Cookson WO, van Duijn CM, Froguel P, Matsuda K, McCarthy MI, Meisinger C, Mooser V, Pietilainen KH, Schumann G, Snieder H, Sternberg MJ, Stolk RP, Thomas HC, Thorsteinsdottir U, Uda M, Waeber G, Wareham NJ, Waterworth DM, 
Watkins H, Whitfield JB, Witteman JC, Wolffenbuttel BH, Fox CS, Ala-Korpela M, Stefansson K, Vollenweider P, Volzke H, Schadt EE, Scott J, Jarvelin MR, Elliott P, Kooner JS. C. Alcohol Genome-wide Association, R. Diabetes Genetics, S. Meta-analyses, C. Genetic Investigation of Anthropometric Traits, C. Global Lipids Genetics, C. Genetics of Liver Disease, P. International Consortium for Blood, G. Meta-analyses of, C. Insulin-Related Traits. Genome-wide association study identifies loci influencing concentrations of liver enzymes in plasma. Nature genetics. 2011; 43:1131-1138. [PubMed: 22001757]

66. Benhamed F, Denechaud PD, Lemoine M, Robichon C, Moldes M, Bertrand-Michel J, Ratziu V, Serfaty L, Housset C, Capeau J, Girard J, Guillou H, Postic C. The lipogenic transcription factor ChREBP dissociates hepatic steatosis from insulin resistance in mice and humans. The Journal of clinical investigation. 2012; 122:2176-2194. [PubMed: 22546860]

67. Iizuka K, Bruick RK, Liang G, Horton JD, Uyeda K. Deficiency of carbohydrate response element-binding protein (ChREBP) reduces lipogenesis as well as glycolysis. Proceedings of the National Academy of Sciences of the United States of America. 2004; 101:7281-7286. [PubMed: 15118080]

68. Dentin R, Benhamed F, Hainault I, Fauveau V, Foufelle F, Dyck JR, Girard J, Postic C. Liverspecific inhibition of ChREBP improves hepatic steatosis and insulin resistance in ob/ob mice. Diabetes. 2006; 55:2159-2170. [PubMed: 16873678]

69. Herman MA, Peroni OD, Villoria J, Schon MR, Abumrad NA, Bluher M, Klein S, Kahn BB. A novel ChREBP isoform in adipose tissue regulates systemic glucose metabolism. Nature. 2012; 484:333-338. [PubMed: 22466288]

70. Donnelly KL, Smith CI, Schwarzenberg SJ, Jessurun J, Boldt MD, Parks EJ. Sources of fatty acids stored in liver and secreted via lipoproteins in patients with nonalcoholic fatty liver disease. The Journal of clinical investigation. 2005; 115:1343-1351. [PubMed: 15864352]

71. Jeong YS, Kim D, Lee YS, Kim HJ, Han JY, Im SS, Chong HK, Kwon JK, Cho YH, Kim WK, Osborne TF, Horton JD, Jun HS, Ahn YH, Ahn SM, Cha JY. Integrated expression profiling and genome-wide analysis of ChREBP targets reveals the dual role for ChREBP in glucose-regulated gene expression. PloS one. 2011; 6:e22544. [PubMed: 21811631]

72. Albrechtsen A, Grarup N, Li Y, Sparso T, Tian G, Cao H, Jiang T, Kim SY, Korneliussen T, Li Q, Nie C, Wu R, Skotte L, Morris AP, Ladenvall C, Cauchi S, Stancakova A, Andersen G, Astrup A, Banasik K, Bennett AJ, Bolund L, Charpentier G, Chen Y, Dekker JM, Doney AS, Dorkhan M, Forsen T, Frayling TM, Groves CJ, Gui Y, Hallmans G, Hattersley AT, He K, Hitman GA, Holmkvist J, Huang S, Jiang H, Jin X, Justesen JM, Kristiansen K, Kuusisto J, Lajer M, Lantieri O, Li W, Liang H, Liao Q, Liu X, Ma T, Ma X, Manijak MP, Marre M, Mokrosinski J, Morris AD, Mu B, Nielsen AA, Nijpels G, Nilsson P, Palmer CN, Rayner NW, Renstrom F, RibelMadsen R, Robertson N, Rolandsson O, Rossing P, Schwartz TW, Slagboom PE, Sterner M, Consortium D, Tang M, Tarnow L, Tuomi T, van't Riet E, van Leeuwen N, Varga TV, Vestmar MA, Walker M, Wang B, Wang Y, Wu H, Xi F, Yengo L, Yu C, Zhang X, Zhang J, Zhang Q, Zhang W, Zheng H, Zhou Y, Altshuler D, Hart LMt, Franks PW, Balkau B, Froguel P, McCarthy MI, Laakso M, Groop L, Christensen C, Brandslund I, Lauritzen T, Witte DR, Linneberg A, Jorgensen T, Hansen T, Wang J, Nielsen R, Pedersen O. D.E.S.I.R.S. Group. Exome sequencingdriven discovery of coding polymorphisms associated with common metabolic phenotypes. Diabetologia. 2013; 56:298-310. [PubMed: 23160641]

73. Fassett JT, Xu X, Kwak D, Wang H, Liu X, Hu X, Bache RJ, Chen Y. Microtubule Actin CrossLinking Factor 1 Regulates Cardiomyocyte Microtubule Distribution and Adaptation to Hemodynamic Overload. PloS one. 2013; 8:e73887. [PubMed: 24086300]

74. Rees MG, Wincovitch S, Schultz J, Waterstradt R, Beer NL, Baltrusch S, Collins FS, Gloyn AL. Cellular characterisation of the GCKR P446L variant associated with type 2 diabetes risk. Diabetologia. 2012; 55:114-122. [PubMed: 22038520]

75. Cariou B, Capitaine N, Le Marcis V, Vega N, Bereziat V, Kergoat M, Laville M, Girard J, Vidal $\mathrm{H}$, Burnol AF. Increased adipose tissue expression of Grb14 in several models of insulin resistance FASEB journal : official publication of the Federation of American Societies for Experimental. Biology. 2004; 18:965-967. 
76. Carroll EA, Gerrelli D, Gasca S, Berg E, Beier DR, Copp AJ, Klingensmith J. Cordon-bleu is a conserved gene involved in neural tube formation. Developmental biology. 2003; 262:16-31. [PubMed: 14512015]

77. Cooney GJ, Lyons RJ, Crew AJ, Jensen TE, Molero JC, Mitchell CJ, Biden TJ, Ormandy CJ, James DE, Daly RJ. Improved glucose homeostasis and enhanced insulin signalling in Grb14deficient mice. The EMBO journal. 2004; 23:582-593. [PubMed: 14749734]

78. Depetris RS, Hu J, Gimpelevich I, Holt LJ, Daly RJ, Hubbard SR. Structural basis for inhibition of the insulin receptor by the adaptor protein Grb14. Molecular cell. 2005; 20:325-333. [PubMed: 16246733]

79. Gieger C, Radhakrishnan A, Cvejic A, Tang W, Porcu E, Pistis G, Serbanovic-Canic J, Elling U, Goodall AH, Labrune Y, Lopez LM, Magi R, Meacham S, Okada Y, Pirastu N, Sorice R, Teumer A, Voss K, Zhang W, Ramirez-Solis R, Bis JC, Ellinghaus D, Gogele M, Hottenga JJ, Langenberg C, Kovacs P, O'Reilly PF, Shin SY, Esko T, Hartiala J, Kanoni S, Murgia F, Parsa A, Stephens J, van der Harst P, Ellen van der Schoot C, Allayee H, Attwood A, Balkau B, Bastardot F, Basu S, Baumeister SE, Biino G, Bomba L, Bonnefond A, Cambien F, Chambers JC, Cucca F, D'Adamo P, Davies G, de Boer RA, de Geus EJ, Doring A, Elliott P, Erdmann J, Evans DM, Falchi M, Feng W, Folsom AR, Frazer IH, Gibson QD, Glazer NL, Hammond C, Hartikainen AL, Heckbert SR, Hengstenberg C, Hersch M, Illig T, Loos RJ, Jolley J, Khaw KT, Kuhnel B, Kyrtsonis MC, Lagou V, Lloyd-Jones H, Lumley T, Mangino M, Maschio A, Mateo Leach I, McKnight B, Memari Y, Mitchell BD, Montgomery GW, Nakamura Y, Nauck M, Navis G, Nothlings U, Nolte IM, Porteous DJ, Pouta A, Pramstaller PP, Pullat J, Ring SM, Rotter JI, Ruggiero D, Ruokonen A, Sala C, Samani NJ, Sambrook J, Schlessinger D, Schreiber S, Schunkert H, Scott J, Smith NL, Snieder H, Starr JM, Stumvoll M, Takahashi A, Tang WH, Taylor K, Tenesa A, Lay Thein S, Tonjes A, Uda M, Ulivi S, van Veldhuisen DJ, Visscher PM, Volker U, Wichmann HE, Wiggins KL, Willemsen G, Yang TP, Hua Zhao J, Zitting P, Bradley JR, Dedoussis GV, Gasparini P, Hazen SL, Metspalu A, Pirastu M, Shuldiner AR, Joost van Pelt L, Zwaginga JJ, Boomsma DI, Deary IJ, Franke A, Froguel P, Ganesh SK, Jarvelin MR, Martin NG, Meisinger C, Psaty BM, Spector TD, Wareham NJ, Akkerman JW, Ciullo M, Deloukas P, Greinacher A, Jupe S, Kamatani N, Khadake J, Kooner JS, Penninger J, Prokopenko I, Stemple D, Toniolo D, Wernisch L, Sanna S, Hicks AA, Rendon A, Ferreira MA, Ouwehand WH, Soranzo N. New gene functions in megakaryopoiesis and platelet formation. Nature. 2011; 480:201-208. [PubMed: 22139419]

80. Kraja AT, Vaidya D, Pankow JS, Goodarzi MO, Assimes TL, Kullo IJ, Sovio U, Mathias RA, Sun YV, Franceschini N, Absher D, Li G, Zhang Q, Feitosa MF, Glazer NL, Haritunians T, Hartikainen AL, Knowles JW, North KE, Iribarren C, Kral B, Yanek L, O'Reilly PF, McCarthy MI, Jaquish C, Couper DJ, Chakravarti A, Psaty BM, Becker LC, Province MA, Boerwinkle E, Quertermous T, Palotie L, Jarvelin MR, Becker DM, Kardia SL, Rotter JI, Chen YD, Borecki IB. A bivariate genome-wide approach to metabolic syndrome: STAMPEED consortium. Diabetes. 2011; 60:1329-1339. [PubMed: 21386085]

81. O'Seaghdha CM, Wu H, Yang Q, Kapur K, Guessous I, Zuber AM, Kottgen A, Stoudmann C, Teumer A, Kutalik Z, Mangino M, Dehghan A, Zhang W, Eiriksdottir G, Li G, Tanaka T, Portas L, Lopez LM, Hayward C, Lohman K, Matsuda K, Padmanabhan S, Firsov D, Sorice R, Ulivi S, Brockhaus AC, Kleber ME, Mahajan A, Ernst FD, Gudnason V, Launer LJ, Mace A, Boerwinckle E, Arking DE, Tanikawa C, Nakamura Y, Brown MJ, Gaspoz JM, Theler JM, Siscovick DS, Psaty BM, Bergmann S, Vollenweider P, Vitart V, Wright AF, Zemunik T, Boban M, Kolcic I, Navarro P, Brown EM, Estrada K, Ding J, Harris TB, Bandinelli S, Hernandez D, Singleton AB, Girotto G, Ruggiero D, d'Adamo AP, Robino A, Meitinger T, Meisinger C, Davies G, Starr JM, Chambers JC, Boehm BO, Winkelmann BR, Huang J, Murgia F, Wild SH, Campbell H, Morris AP, Franco OH, Hofman A, Uitterlinden AG, Rivadeneira F, Volker U, Hannemann A, Biffar R, Hoffmann W, Shin SY, Lescuyer P, Henry H, Schurmann C, consortium S, consortium G, Munroe PB, Gasparini P, Pirastu N, Ciullo M, Gieger C, Marz W, Lind L, Spector TD, Smith AV, Rudan I, Wilson JF, Polasek O, Deary IJ, Pirastu M, Ferrucci L, Liu Y, Kestenbaum B, Kooner JS, Witteman JC, Nauck M, Kao WH, Wallaschofski H, Bonny O, Fox CS, Bochud M. Meta-analysis of genome-wide association studies identifies six new Loci for serum calcium concentrations. PLoS genetics. 2013; 9:e1003796. [PubMed: 24068962]

82. Rung J, Cauchi S, Albrechtsen A, Shen L, Rocheleau G, Cavalcanti-Proenca C, Bacot F, Balkau B, Belisle A, Borch-Johnsen K, Charpentier G, Dina C, Durand E, Elliott P, Hadjadj S, Jarvelin MR, 
Laitinen J, Lauritzen T, Marre M, Mazur A, Meyre D, Montpetit A, Pisinger C, Posner B, Poulsen P, Pouta A, Prentki M, Ribel-Madsen R, Ruokonen A, Sandbaek A, Serre D, Tichet J, Vaxillaire M, Wojtaszewski JF, Vaag A, Hansen T, Polychronakos C, Pedersen O, Froguel P, Sladek R. Genetic variant near IRS1 is associated with type 2 diabetes, insulin resistance and hyperinsulinemia. Nature genetics. 2009; 41:1110-1115. [PubMed: 19734900]

83. Samani NJ, Erdmann J, Hall AS, Hengstenberg C, Mangino M, Mayer B, Dixon RJ, Meitinger T, Braund P, Wichmann HE, Barrett JH, Konig IR, Stevens SE, Szymczak S, Tregouet DA, Iles MM, Pahlke F, Pollard H, Lieb W, Cambien F, Fischer M, Ouwehand W, Blankenberg S, Balmforth AJ, Baessler A, Ball SG, Strom TM, Braenne I, Gieger C, Deloukas P, Tobin MD, Ziegler A, Thompson JR, Schunkert H. Wtccc, C. the Cardiogenics, Genomewide association analysis of coronary artery disease. The New England journal of medicine. 2007; 357:443-453. [PubMed: 17634449]

84. Santoro N, Zhang CK, Zhao H, Pakstis AJ, Kim G, Kursawe R, Dykas DJ, Bale AE, Giannini C, Pierpont B, Shaw MM, Groop L, Caprio S. Variant in the glucokinase regulatory protein (GCKR) gene is associated with fatty liver in obese children and adolescents. Hepatology. 2012; 55:781789. [PubMed: 22105854]

85. Stancakova A, Civelek M, Saleem NK, Soininen P, Kangas AJ, Cederberg H, Paananen J, Pihlajamaki J, Bonnycastle LL, Morken MA, Boehnke M, Pajukanta P, Lusis AJ, Collins FS, Kuusisto J, Ala-Korpela M, Laakso M. Hyperglycemia and a common variant of GCKR are associated with the levels of eight amino acids in 9,369 Finnish men. Diabetes. 2012; 61:18951902. [PubMed: 22553379]

86. Stolk L, Perry JR, Chasman DI, He C, Mangino M, Sulem P, Barbalic M, Broer L, Byrne EM, Ernst F, Esko T, Franceschini N, Gudbjartsson DF, Hottenga JJ, Kraft P, McArdle PF, Porcu E, Shin SY, Smith AV, van Wingerden S, Zhai G, Zhuang WV, Albrecht E, Alizadeh BZ, Aspelund T, Bandinelli S, Lauc LB, Beckmann JS, Boban M, Boerwinkle E, Broekmans FJ, Burri A, Campbell H, Chanock SJ, Chen C, Cornelis MC, Corre T, Coviello AD, d'Adamo P, Davies G, de Faire U, de Geus EJ, Deary IJ, Dedoussis GV, Deloukas P, Ebrahim S, Eiriksdottir G, Emilsson V, Eriksson JG, Fauser BC, Ferreli L, Ferrucci L, Fischer K, Folsom AR, Garcia ME, Gasparini P, Gieger C, Glazer N, Grobbee DE, Hall P, Haller T, Hankinson SE, Hass M, Hayward C, Heath AC, Hofman A, Ingelsson E, Janssens AC, Johnson AD, Karasik D, Kardia SL, Keyzer J, Kiel DP, Kolcic I, Kutalik Z, Lahti J, Lai S, Laisk T, Laven JS, Lawlor DA, Liu J, Lopez LM, Louwers YV, Magnusson PK, Marongiu M, Martin NG, Klaric IM, Masciullo C, McKnight B, Medland SE, Melzer D, Mooser V, Navarro P, Newman AB, Nyholt DR, Onland-Moret NC, Palotie A, Pare G, Parker AN, Pedersen NL, Peeters PH, Pistis G, Plump AS, Polasek O, Pop VJ, Psaty BM, Raikkonen K, Rehnberg E, Rotter JI, Rudan I, Sala C, Salumets A, Scuteri A, Singleton A, Smith JA, Snieder H, Soranzo N, Stacey SN, Starr JM, Stathopoulou MG, Stirrups K, Stolk RP, Styrkarsdottir U, Sun YV, Tenesa A, Thorand B, Toniolo D, Tryggvadottir L, Tsui K, Ulivi S, van Dam RM, van der Schouw YT, van Gils CH, van Nierop P, Vink JM, Visscher PM, Voorhuis M, Waeber G, Wallaschofski H, Wichmann HE, Widen E, Wijnands-van Gent CJ, Willemsen G, Wilson JF, Wolffenbuttel BH, Wright AF, Yerges-Armstrong LM, Zemunik T, Zgaga L, Zillikens MC, Zygmunt M, Study TL, Arnold AM, Boomsma DI, Buring JE, Crisponi L, Demerath EW, Gudnason V, Harris TB, Hu FB, Hunter DJ, Launer LJ, Metspalu A, Montgomery GW, Oostra BA, Ridker PM, Sanna S, Schlessinger D, Spector TD, Stefansson K, Streeten EA, Thorsteinsdottir U, Uda M, Uitterlinden AG, van Duijn CM, Volzke H, Murray A, Murabito JM, Visser JA, Lunetta KL. Meta-analyses identify 13 loci associated with age at menopause and highlight DNA repair and immune pathways. Nature genetics. 2012; 44:260-268. [PubMed: 22267201]

87. Aulchenko YS, Ripatti S, Lindqvist I, Boomsma D, Heid IM, Pramstaller PP, Penninx BW, Janssens AC, Wilson JF, Spector T, Martin NG, Pedersen NL, Kyvik KO, Kaprio J, Hofman A, Freimer NB, Jarvelin MR, Gyllensten U, Campbell H, Rudan I, Johansson A, Marroni F, Hayward C, Vitart V, Jonasson I, Pattaro C, Wright A, Hastie N, Pichler I, Hicks AA, Falchi M, Willemsen G, Hottenga JJ, de Geus EJ, Montgomery GW, Whitfield J, Magnusson P, Saharinen J, Perola M, Silander K, Isaacs A, Sijbrands EJ, Uitterlinden AG, Witteman JC, Oostra BA, Elliott P, Ruokonen A, Sabatti C, Gieger C, Meitinger T, Kronenberg F, Doring A, Wichmann HE, Smit JH, McCarthy MI, van Duijn CM, Peltonen L, Consortium E. Loci influencing lipid levels and 
coronary heart disease risk in 16 European population cohorts. Nature genetics. 2009; 41:47-55. [PubMed: 19060911]

88. Chambers JC, Elliott P, Zabaneh D, Zhang W, Li Y, Froguel P, Balding D, Scott J, Kooner JS. Common genetic variation near MC4R is associated with waist circumference and insulin resistance. Nature genetics. 2008; 40:716-718. [PubMed: 18454146]

89. Saxena R, Voight BF, Lyssenko V, Burtt NP, de Bakker PI, Chen H, Roix JJ, Kathiresan S, Hirschhorn JN, Daly MJ, Hughes TE, Groop L, Altshuler D, Almgren P, Florez JC, Meyer J, Ardlie K, Bengtsson Bostrom K, Isomaa B, Lettre G, Lindblad U, Lyon HN, Melander O, Newton-Cheh C, Nilsson P, Orho-Melander M, Rastam L, Speliotes EK, Taskinen MR, Tuomi T, Guiducci C, Berglund A, Carlson J, Gianniny L, Hackett R, Hall L, Holmkvist J, Laurila E, Sjogren M, Sterner M, Surti A, Svensson M, Svensson M, Tewhey R, Blumenstiel B, Parkin M, Defelice M, Barry R, Brodeur W, Camarata J, Chia N, Fava M, Gibbons J, Handsaker B, Healy C, Nguyen K, Gates C, Sougnez C, Gage D, Nizzari M, Gabriel SB, Chirn GW, Ma Q, Parikh H, Richardson D, Ricke D, Purcell S. H. Diabetes Genetics Initiative of Broad Institute of, L.U. Mit, R. Novartis Institutes of BioMedical. Genome-wide association analysis identifies loci for type 2 diabetes and triglyceride levels. Science. 2007; 316:1331-1336. [PubMed: 17463246]

90. Heid IM, Boes E, Muller M, Kollerits B, Lamina C, Coassin S, Gieger C, Doring A, Klopp N, Frikke-Schmidt R, Tybjaerg-Hansen A, Brandstatter A, Luchner A, Meitinger T, Wichmann HE, Kronenberg F. Genome-wide association analysis of high-density lipoprotein cholesterol in the population-based KORA study sheds new light on intergenic regions Circulation. Cardiovascular genetics. 2008; 1:10-20. [PubMed: 20031538]

91. Johansen CT, Wang J, Lanktree MB, Cao H, McIntyre AD, Ban MR, Martins RA, Kennedy BA, Hassell RG, Visser ME, Schwartz SM, Voight BF, Elosua R, Salomaa V, O'Donnell CJ, DallingaThie GM, Anand SS, Yusuf S, Huff MW, Kathiresan S, Hegele RA. Excess of rare variants in genes identified by genome-wide association study of hypertriglyceridemia. Nature genetics. 2010; 42:684-687. [PubMed: 20657596]

92. Kathiresan S, Manning AK, Demissie S, D'Agostino RB, Surti A, Guiducci C, Gianniny L, Burtt NP, Melander O, Orho-Melander M, Arnett DK, Peloso GM, Ordovas JM, Cupples LA. A genome-wide association study for blood lipid phenotypes in the Framingham Heart Study. BMC medical genetics. 2007; 8(Supp 1):S17. [PubMed: 17903299]

93. Kathiresan S, Willer CJ, Peloso GM, Demissie S, Musunuru K, Schadt EE, Kaplan L, Bennett D, Li Y, Tanaka T, Voight BF, Bonnycastle LL, Jackson AU, Crawford G, Surti A, Guiducci C, Burtt NP, Parish S, Clarke R, Zelenika D, Kubalanza KA, Morken MA, Scott LJ, Stringham HM, Galan P, Swift AJ, Kuusisto J, Bergman RN, Sundvall J, Laakso M, Ferrucci L, Scheet P, Sanna S, Uda M, Yang Q, Lunetta KL, Dupuis J, de Bakker PI, O'Donnell CJ, Chambers JC, Kooner JS, Hercberg S, Meneton P, Lakatta EG, Scuteri A, Schlessinger D, Tuomilehto J, Collins FS, Groop L, Altshuler D, Collins R, Lathrop GM, Melander O, Salomaa V, Peltonen L, Orho-Melander M, Ordovas JM, Boehnke M, Abecasis GR, Mohlke KL, Cupples LA. Common variants at 30 loci contribute to polygenic dyslipidemia. Nature genetics. 2009; 41:56-65. [PubMed: 19060906]

94. Kilpelainen TO, Zillikens MC, Stancakova A, Finucane FM, Ried JS, Langenberg C, Zhang W, Beckmann JS, Luan J, Vandenput L, Styrkarsdottir U, Zhou Y, Smith AV, Zhao JH, Amin N, Vedantam S, Shin SY, Haritunians T, Fu M, Feitosa MF, Kumari M, Halldorsson BV, Tikkanen E, Mangino M, Hayward C, Song C, Arnold AM, Aulchenko YS, Oostra BA, Campbell H, Cupples LA, Davis KE, Doring A, Eiriksdottir G, Estrada K, Fernandez-Real JM, Garcia M, Gieger C, Glazer NL, Guiducci C, Hofman A, Humphries SE, Isomaa B, Jacobs LC, Jula A, Karasik D, Karlsson MK, Khaw KT, Kim LJ, Kivimaki M, Klopp N, Kuhnel B, Kuusisto J, Liu Y, Ljunggren O, Lorentzon M, Luben RN, McKnight B, Mellstrom D, Mitchell BD, Mooser V, Moreno JM, Mannisto S, O'Connell JR, Pascoe L, Peltonen L, Peral B, Perola M, Psaty BM, Salomaa V, Savage DB, Semple RK, Skaric-Juric T, Sigurdsson G, Song KS, Spector TD, Syvanen AC, Talmud PJ, Thorleifsson G, Thorsteinsdottir U, Uitterlinden AG, van Duijn CM, Vidal-Puig A, Wild SH, Wright AF, Clegg DJ, Schadt E, Wilson JF, Rudan I, Ripatti S, Borecki IB, Shuldiner AR, Ingelsson E, Jansson JO, Kaplan RC, Gudnason V, Harris TB, Groop L, Kiel DP, Rivadeneira F, Walker M, Barroso I, Vollenweider P, Waeber G, Chambers JC, Kooner JS, Soranzo N, Hirschhorn JN, Stefansson K, Wichmann HE, Ohlsson C, O'Rahilly S, Wareham NJ, Speliotes EK, Fox CS, Laakso M, Loos RJ. Genetic variation near IRS1 associates with reduced adiposity and an impaired metabolic profile. Nature genetics. 2011; 43:753-760. [PubMed: 21706003] 
95. Middelberg RP, Ferreira MA, Henders AK, Heath AC, Madden PA, Montgomery GW, Martin NG, Whitfield JB. Genetic variants in LPL, OASL and TOMM40/APOE-C1-C2-C4 genes are associated with multiple cardiovascular-related traits. BMC medical genetics. 2011; 12:123. [PubMed: 21943158]

96. Sabatti C, Service SK, Hartikainen AL, Pouta A, Ripatti S, Brodsky J, Jones CG, Zaitlen NA, Varilo T, Kaakinen M, Sovio U, Ruokonen A, Laitinen J, Jakkula E, Coin L, Hoggart C, Collins A, Turunen H, Gabriel S, Elliot P, McCarthy MI, Daly MJ, Jarvelin MR, Freimer NB, Peltonen L. Genome-wide association analysis of metabolic traits in a birth cohort from a founder population. Nature genetics. 2009; 41:35-46. [PubMed: 19060910]

97. Tan A, Sun J, Xia N, Qin X, Hu Y, Zhang S, Tao S, Gao Y, Yang X, Zhang H, Kim ST, Peng T, Lin X, Li L, Mo L, Liang Z, Shi D, Huang Z, Huang X, Liu M, Ding Q, Trent JM, Zheng SL, Mo $\mathrm{Z}, \mathrm{Xu}$ J. A genome-wide association and gene-environment interaction study for serum triglycerides levels in a healthy Chinese male population. Human molecular genetics. 2012; 21:1658-1664. [PubMed: 22171074]

98. Voight BF, Scott LJ, Steinthorsdottir V, Morris AP, Dina C, Welch RP, Zeggini E, Huth C, Aulchenko YS, Thorleifsson G, McCulloch LJ, Ferreira T, Grallert H, Amin N, Wu G, Willer CJ, Raychaudhuri S, McCarroll SA, Langenberg C, Hofmann OM, Dupuis J, Qi L, Segre AV, van Hoek M, Navarro P, Ardlie K, Balkau B, Benediktsson R, Bennett AJ, Blagieva R, Boerwinkle E, Bonnycastle LL, Bengtsson Bostrom K, Bravenboer B, Bumpstead S, Burtt NP, Charpentier G, Chines PS, Cornelis M, Couper DJ, Crawford G, Doney AS, Elliott KS, Elliott AL, Erdos MR, Fox CS, Franklin CS, Ganser M, Gieger C, Grarup N, Green T, Griffin S, Groves CJ, Guiducci C, Hadjadj S, Hassanali N, Herder C, Isomaa B, Jackson AU, Johnson PR, Jorgensen T, Kao WH, Klopp N, Kong A, Kraft P, Kuusisto J, Lauritzen T, Li M, Lieverse A, Lindgren CM, Lyssenko V, Marre M, Meitinger T, Midthjell K, Morken MA, Narisu N, Nilsson P, Owen KR, Payne F, Perry JR, Petersen AK, Platou C, Proenca C, Prokopenko I, Rathmann W, Rayner NW, Robertson NR, Rocheleau G, Roden M, Sampson MJ, Saxena R, Shields BM, Shrader P, Sigurdsson G, Sparso T, Strassburger K, Stringham HM, Sun Q, Swift AJ, Thorand B, Tichet J, Tuomi T, van Dam RM, van Haeften TW, van Herpt T, van Vliet-Ostaptchouk JV, Walters GB, Weedon MN, Wijmenga C, Witteman J, Bergman RN, Cauchi S, Collins FS, Gloyn AL, Gyllensten U, Hansen T, Hide WA, Hitman GA, Hofman A, Hunter DJ, Hveem K, Laakso M, Mohlke KL, Morris AD, Palmer CN, Pramstaller PP, Rudan I, Sijbrands E, Stein LD, Tuomilehto J, Uitterlinden A, Walker M, Wareham NJ, Watanabe RM, Abecasis GR, Boehm BO, Campbell H, Daly MJ, Hattersley AT, Hu FB, Meigs JB, Pankow JS, Pedersen O, Wichmann HE, Barroso I, Florez JC, Frayling TM, Groop L, Sladek R, Thorsteinsdottir U, Wilson JF, Illig T, Froguel P, van Duijn CM, Stefansson K, Altshuler D, Boehnke M, McCarthy MI. M. investigators, G. Consortium. Twelve type 2 diabetes susceptibility loci identified through large-scale association analysis. Nature genetics. 2010; 42:579-589. [PubMed: 20581827]

99. Zabaneh D, Balding DJ. A genome-wide association study of the metabolic syndrome in Indian Asian men. PloS one. 2010; 5:e11961. [PubMed: 20694148]

100. Akira S, Misawa T, Satoh T, Saitoh T. Macrophages control innate inflammation. Diabetes, obesity \& metabolism. 2013; 15(Suppl 3):10-18.

101. Barrett JC, Hansoul S, Nicolae DL, Cho JH, Duerr RH, Rioux JD, Brant SR, Silverberg MS, Taylor KD, Barmada MM, Bitton A, Dassopoulos T, Datta LW, Green T, Griffiths AM, Kistner EO, Murtha MT, Regueiro MD, Rotter JI, Schumm LP, Steinhart AH, Targan SR, Xavier RJ, Consortium NIG, Libioulle C, Sandor C, Lathrop M, Belaiche J, Dewit O, Gut I, Heath S, Laukens D, Mni M, Rutgeerts P, Van Gossum A, Zelenika D, Franchimont D, Hugot JP, de Vos M, Vermeire S, Louis E, Belgian-French IBDC, Cardon LR, Anderson CA, Drummond H, Nimmo E, Ahmad T, Prescott NJ, Onnie CM, Fisher SA, Marchini J, Ghori J, Bumpstead S, Gwilliam R, Tremelling M, Deloukas P, Mansfield J, Jewell D, Satsangi J, Mathew CG, Parkes M, Georges M, Daly MJ. C. Wellcome Trust Case Control. Genome-wide association defines more than 30 distinct susceptibility loci for Crohn's disease. Nature genetics. 2008; 40:955-962. [PubMed: 18587394]

102. Demirkan A, van Duijn CM, Ugocsai P, Isaacs A, Pramstaller PP, Liebisch G, Wilson JF, Johansson A, Rudan I, Aulchenko YS, Kirichenko AV, Janssens AC, Jansen RC, Gnewuch C, Domingues FS, Pattaro C, Wild SH, Jonasson I, Polasek O, Zorkoltseva IV, Hofman A, Karssen LC, Struchalin M, Floyd J, Igl W, Biloglav Z, Broer L, Pfeufer A, Pichler I, Campbell S, Zaboli 
G, Kolcic I, Rivadeneira F, Huffman J, Hastie ND, Uitterlinden A, Franke L, Franklin CS, Vitart V, Consortium D, Nelson CP, Preuss M, Consortium CA, Bis JC, O'Donnell CJ, Franceschini N, Consortium C, Witteman JC, Axenovich T, Oostra BA, Meitinger T, Hicks AA, Hayward C, Wright AF, Gyllensten U, Campbell H, Schmitz G. E. consortium, Genome-wide association study identifies novel loci associated with circulating phospho- and sphingolipid concentrations. PLoS genetics. 2012; 8:e1002490. [PubMed: 22359512]

103. Fox CS, Liu Y, White CC, Feitosa M, Smith AV, Heard-Costa N, Lohman K, Consortium G, Consortium M, Consortium G, Johnson AD, Foster MC, Greenawalt DM, Griffin P, Ding J, Newman AB, Tylavsky F, Miljkovic I, Kritchevsky SB, Launer L, Garcia M, Eiriksdottir G, Carr JJ, Gudnason V, Harris TB, Cupples LA, Borecki IB. Genome-wide association for abdominal subcutaneous and visceral adipose reveals a novel locus for visceral fat in women. PLoS genetics. 2012; 8:e1002695. [PubMed: 22589738]

104. Harold D, Abraham R, Hollingworth P, Sims R, Gerrish A, Hamshere ML, Pahwa JS, Moskvina V, Dowzell K, Williams A, Jones N, Thomas C, Stretton A, Morgan AR, Lovestone S, Powell J, Proitsi P, Lupton MK, Brayne C, Rubinsztein DC, Gill M, Lawlor B, Lynch A, Morgan K, Brown KS, Passmore PA, Craig D, McGuinness B, Todd S, Holmes C, Mann D, Smith AD, Love S, Kehoe PG, Hardy J, Mead S, Fox N, Rossor M, Collinge J, Maier W, Jessen F, Schurmann B, van den Bussche H, Heuser I, Kornhuber J, Wiltfang J, Dichgans M, Frolich L, Hampel H, Hull M, Rujescu D, Goate AM, Kauwe JS, Cruchaga C, Nowotny P, Morris JC, Mayo K, Sleegers K, Bettens K, Engelborghs S, De Deyn PP, Van Broeckhoven C, Livingston G, Bass NJ, Gurling H, McQuillin A, Gwilliam R, Deloukas P, Al-Chalabi A, Shaw CE, Tsolaki M, Singleton AB, Guerreiro R, Muhleisen TW, Nothen MM, Moebus S, Jockel KH, Klopp N, Wichmann HE, Carrasquillo MM, Pankratz VS, Younkin SG, Holmans PA, O'Donovan M, Owen MJ, Williams J. Genome-wide association study identifies variants at CLU and PICALM associated with Alzheimer's disease. Nature genetics. 2009; 41:1088-1093. [PubMed: 19734902]

105. Heard-Costa NL, Zillikens MC, Monda KL, Johansson A, Harris TB, Fu M, Haritunians T, Feitosa MF, Aspelund T, Eiriksdottir G, Garcia M, Launer LJ, Smith AV, Mitchell BD, McArdle PF, Shuldiner AR, Bielinski SJ, Boerwinkle E, Brancati F, Demerath EW, Pankow JS, Arnold AM, Chen YD, Glazer NL, McKnight B, Psaty BM, Rotter JI, Amin N, Campbell H, Gyllensten U, Pattaro C, Pramstaller PP, Rudan I, Struchalin M, Vitart V, Gao X, Kraja A, Province MA, Zhang Q, Atwood LD, Dupuis J, Hirschhorn JN, Jaquish CE, O'Donnell CJ, Vasan RS, White CC, Aulchenko YS, Estrada K, Hofman A, Rivadeneira F, Uitterlinden AG, Witteman JC, Oostra BA, Kaplan RC, Gudnason V, O'Connell JR, Borecki IB, van Duijn CM, Cupples LA, Fox CS, North KE. NRXN3 is a novel locus for waist circumference: a genome-wide association study from the CHARGE Consortium. PLoS genetics. 2009; 5:e1000539. [PubMed: 19557197]

106. Hafler DA, Compston A, Sawcer S, Lander ES, Daly MJ, De Jager PL, de Bakker PI, Gabriel SB, Mirel DB, Ivinson AJ, Pericak-Vance MA, Gregory SG, Rioux JD, McCauley JL, Haines JL, Barcellos LF, Cree B, Oksenberg JR, Hauser SL. C. International Multiple Sclerosis Genetics. Risk alleles for multiple sclerosis identified by a genomewide study. The New England journal of medicine. 2007; 357:851-862. [PubMed: 17660530]

107. Lemaitre RN, Tanaka T, Tang W, Manichaikul A, Foy M, Kabagambe EK, Nettleton JA, King IB, Weng LC, Bhattacharya S, Bandinelli S, Bis JC, Rich SS, Jacobs DR Jr, Cherubini A, McKnight B, Liang S, Gu X, Rice K, Laurie CC, Lumley T, Browning BL, Psaty BM, Chen YD, Friedlander Y, Djousse L, Wu JH, Siscovick DS, Uitterlinden AG, Arnett DK, Ferrucci L, Fornage M, Tsai MY, Mozaffarian D, Steffen LM. Genetic loci associated with plasma phospholipid n-3 fatty acids: a meta-analysis of genome-wide association studies from the CHARGE Consortium. PLoS genetics. 2011; 7:e1002193. [PubMed: 21829377]

108. Lindgren CM, Heid IM, Randall JC, Lamina C, Steinthorsdottir V, Qi L, Speliotes EK, Thorleifsson G, Willer CJ, Herrera BM, Jackson AU, Lim N, Scheet P, Soranzo N, Amin N, Aulchenko YS, Chambers JC, Drong A, Luan J, Lyon HN, Rivadeneira F, Sanna S, Timpson NJ, Zillikens MC, Zhao JH, Almgren P, Bandinelli S, Bennett AJ, Bergman RN, Bonnycastle LL, Bumpstead SJ, Chanock SJ, Cherkas L, Chines P, Coin L, Cooper C, Crawford G, Doering A, Dominiczak A, Doney AS, Ebrahim S, Elliott P, Erdos MR, Estrada K, Ferrucci L, Fischer G, Forouhi NG, Gieger C, Grallert H, Groves CJ, Grundy S, Guiducci C, Hadley D, Hamsten A, Havulinna AS, Hofman A, Holle R, Holloway JW, Illig T, Isomaa B, Jacobs LC, Jameson K, Jousilahti P, Karpe F, Kuusisto J, Laitinen J, Lathrop GM, Lawlor DA, Mangino M, McArdle 
WL, Meitinger T, Morken MA, Morris AP, Munroe P, Narisu N, Nordstrom A, Nordstrom P, Oostra BA, Palmer CN, Payne F, Peden JF, Prokopenko I, Renstrom F, Ruokonen A, Salomaa V, Sandhu MS, Scott LJ, Scuteri A, Silander K, Song K, Yuan X, Stringham HM, Swift AJ, Tuomi T, Uda M, Vollenweider P, Waeber G, Wallace C, Walters GB, Weedon MN, Witteman JC, Zhang C, Zhang W, Caulfield MJ, Collins FS, Davey Smith G, Day IN, Franks PW, Hattersley AT, Hu FB, Jarvelin MR, Kong A, Kooner JS, Laakso M, Lakatta E, Mooser V, Morris AD, Peltonen L, Samani NJ, Spector TD, Strachan DP, Tanaka T, Tuomilehto J, Uitterlinden AG, van Duijn CM, Wareham NJ, Hugh W, Procardis C, Waterworth DM, Boehnke M, Deloukas P, Groop L, Hunter DJ, Thorsteinsdottir U, Schlessinger D, Wichmann HE, Frayling TM, Abecasis GR, Hirschhorn JN, Loos RJ, Stefansson K, Mohlke KL, Barroso I, McCarthy MI, Giant C. C. Wellcome Trust Case Control. Genome-wide association scan meta-analysis identifies three Loci influencing adiposity and fat distribution. PLoS genetics. 2009; 5:e1000508. [PubMed: 19557161]

109. Liu MJ, Bao S, Galvez-Peralta M, Pyle CJ, Rudawsky AC, Pavlovicz RE, Killilea DW, Li C, Nebert DW, Wewers MD, Knoell DL. ZIP8 regulates host defense through zinc-mediated inhibition of NF-kappaB. Cell reports. 2013; 3:386-400. [PubMed: 23403290]

110. Liuzzi JP, Lichten LA, Rivera S, Blanchard RK, Aydemir TB, Knutson MD, Ganz T, Cousins RJ Interleukin- 6 regulates the zinc transporter Zip14 in liver and contributes to the hypozincemia of the acute-phase response. Proceedings of the National Academy of Sciences of the United States of America. 2005; 102:6843-6848. [PubMed: 15863613]

111. Meyre D, Delplanque J, Chevre JC, Lecoeur C, Lobbens S, Gallina S, Durand E, Vatin V, Degraeve F, Proenca C, Gaget S, Korner A, Kovacs P, Kiess W, Tichet J, Marre M, Hartikainen AL, Horber F, Potoczna N, Hercberg S, Levy-Marchal C, Pattou F, Heude B, Tauber M, McCarthy MI, Blakemore AI, Montpetit A, Polychronakos C, Weill J, Coin LJ, Asher J, Elliott P, Jarvelin MR, Visvikis-Siest S, Balkau B, Sladek R, Balding D, Walley A, Dina C, Froguel P. Genome-wide association study for early-onset and morbid adult obesity identifies three new risk loci in European populations. Nature genetics. 2009; 41:157-159. [PubMed: 19151714]

112. O'Donnell CJ, Cupples LA, D'Agostino RB, Fox CS, Hoffmann U, Hwang SJ, Ingellson E, Liu C, Murabito JM, Polak JF, Wolf PA, Demissie S. Genome-wide association study for subclinical atherosclerosis in major arterial territories in the NHLBI's Framingham Heart Study. BMC medical genetics. 2007; 8(Suppl 1):S4. [PubMed: 17903303]

113. Reiner AP, Barber MJ, Guan Y, Ridker PM, Lange LA, Chasman DI, Walston JD, Cooper GM, Jenny NS, Rieder MJ, Durda JP, Smith JD, Novembre J, Tracy RP, Rotter JI, Stephens M, Nickerson DA, Krauss RM. Polymorphisms of the HNF1A gene encoding hepatocyte nuclear factor-1 alpha are associated with C-reactive protein. American journal of human genetics. 2008; 82:1193-1201. [PubMed: 18439552]

114. Seshadri S, Fitzpatrick AL, Ikram MA, DeStefano AL, Gudnason V, Boada M, Bis JC, Smith AV, Carassquillo MM, Lambert JC, Harold D, Schrijvers EM, Ramirez-Lorca R, Debette S, Longstreth WT Jr, Janssens AC, Pankratz VS, Dartigues JF, Hollingworth P, Aspelund T, Hernandez I, Beiser A, Kuller LH, Koudstaal PJ, Dickson DW, Tzourio C, Abraham R, Antunez C, Du Y, Rotter JI, Aulchenko YS, Harris TB, Petersen RC, Berr C, Owen MJ, Lopez-Arrieta J, Varadarajan BN, Becker JT, Rivadeneira F, Nalls MA, Graff-Radford NR, Campion D, Auerbach S, Rice K, Hofman A, Jonsson PV, Schmidt H, Lathrop M, Mosley TH, Au R, Psaty BM, Uitterlinden AG, Farrer LA, Lumley T, Ruiz A, Williams J, Amouyel P, Younkin SG, Wolf PA, Launer LJ, Lopez OL, van Duijn CM, Breteler MM, Consortium C, Consortium G, Consortium E. Genome-wide analysis of genetic loci associated with Alzheimer disease. JAMA : the journal of the American Medical Association. 2010; 303:1832-1840. [PubMed: 20460622]

115. Soranzo N, Spector TD, Mangino M, Kuhnel B, Rendon A, Teumer A, Willenborg C, Wright B, Chen L, Li M, Salo P, Voight BF, Burns P, Laskowski RA, Xue Y, Menzel S, Altshuler D, Bradley JR, Bumpstead S, Burnett MS, Devaney J, Doring A, Elosua R, Epstein SE, Erber W, Falchi M, Garner SF, Ghori MJ, Goodall AH, Gwilliam R, Hakonarson HH, Hall AS, Hammond N, Hengstenberg C, Illig T, Konig IR, Knouff CW, McPherson R, Melander O, Mooser V, Nauck M, Nieminen MS, O'Donnell CJ, Peltonen L, Potter SC, Prokisch H, Rader DJ, Rice CM, Roberts R, Salomaa V, Sambrook J, Schreiber S, Schunkert H, Schwartz SM, Serbanovic-Canic J, Sinisalo J, Siscovick DS, Stark K, Surakka I, Stephens J, Thompson JR, Volker U, Volzke H, Watkins NA, Wells GA, Wichmann HE, Van Heel DA, Tyler-Smith C, Thein SL, Kathiresan S, 
Perola M, Reilly MP, Stewart AF, Erdmann J, Samani NJ, Meisinger C, Greinacher A, Deloukas P, Ouwehand WH, Gieger C. A genome-wide meta-analysis identifies 22 loci associated with eight hematological parameters in the HaemGen consortium. Nature genetics. 2009; 41:11821190. [PubMed: 19820697]

116. Staubert C, Tarnow P, Brumm H, Pitra C, Gudermann T, Gruters A, Schoneberg T, Biebermann $\mathrm{H}$, Rompler $\mathrm{H}$. Evolutionary aspects in evaluating mutations in the melanocortin 4 receptor. Endocrinology. 2007; 148:4642-4648. [PubMed: 17628007]

117. Stocks T, Angquist L, Banasik K, Harder MN, Taylor MA, Hager J, Arner P, Oppert JM, Martinez JA, Polak J, Rousseau F, Langin D, Rossner S, Holst C, MacDonald IA, Kamatani Y, Pfeiffer AF, Kunesova M, Saris WH, Hansen T, Pedersen O, Astrup A, Sorensen TI. TFAP2B influences the effect of dietary fat on weight loss under energy restriction. PloS one. 2012; 7:e43212. [PubMed: 22952648]

118. Suhre K, Shin SY, Petersen AK, Mohney RP, Meredith D, Wagele B, Altmaier E, CardioGram, Deloukas P, Erdmann J, Grundberg E, Hammond CJ, de Angelis MH, Kastenmuller G, Kottgen A, Kronenberg F, Mangino M, Meisinger C, Meitinger T, Mewes HW, Milburn MV, Prehn C, Raffler J, Ried JS, Romisch-Margl W, Samani NJ, Small KS, Wichmann HE, Zhai G, Illig T, Spector TD, Adamski J, Soranzo N, Gieger C. Human metabolic individuality in biomedical and pharmaceutical research. Nature. 2011; 477:54-60. [PubMed: 21886157]

119. Thorleifsson G, Walters GB, Gudbjartsson DF, Steinthorsdottir V, Sulem P, Helgadottir A, Styrkarsdottir U, Gretarsdottir S, Thorlacius S, Jonsdottir I, Jonsdottir T, Olafsdottir EJ, Olafsdottir GH, Jonsson T, Jonsson F, Borch-Johnsen K, Hansen T, Andersen G, Jorgensen T, Lauritzen T, Aben KK, Verbeek AL, Roeleveld N, Kampman E, Yanek LR, Becker LC, Tryggvadottir L, Rafnar T, Becker DM, Gulcher J, Kiemeney LA, Pedersen O, Kong A, Thorsteinsdottir U, Stefansson K. Genome-wide association yields new sequence variants at seven loci that associate with measures of obesity. Nature genetics. 2009; 41:18-24. [PubMed: 19079260]

120. Yang Q, Kathiresan S, Lin JP, Tofler GH, O'Donnell CJ. Genome-wide association and linkage analyses of hemostatic factors and hematological phenotypes in the Framingham Heart Study. BMC medical genetics. 2007; 8(Suppl 1):S12. [PubMed: 17903294]

121. Zeggini E, Weedon MN, Lindgren CM, Frayling TM, Elliott KS, Lango H, Timpson NJ, Perry JR, Rayner NW, Freathy RM, Barrett JC, Shields B, Morris AP, Ellard S, Groves CJ, Harries LW, Marchini JL, Owen KR, Knight B, Cardon LR, Walker M, Hitman GA, Morris AD, Doney AS, McCarthy MI, Hattersley AT. C. Wellcome Trust Case Control. Replication of genome-wide association signals in UK samples reveals risk loci for type 2 diabetes. Science. 2007; 316:13361341. [PubMed: 17463249]

122. Lango Allen H, Estrada K, Lettre G, Berndt SI, Weedon MN, Rivadeneira F, Willer CJ, Jackson AU, Vedantam S, Raychaudhuri S, Ferreira T, Wood AR, Weyant RJ, Segre AV, Speliotes EK, Wheeler E, Soranzo N, Park JH, Yang J, Gudbjartsson D, Heard-Costa NL, Randall JC, Qi L, Vernon Smith A, Magi R, Pastinen T, Liang L, Heid IM, Luan J, Thorleifsson G, Winkler TW, Goddard ME, Sin Lo K, Palmer C, Workalemahu T, Aulchenko YS, Johansson A, Zillikens MC, Feitosa MF, Esko T, Johnson T, Ketkar S, Kraft P, Mangino M, Prokopenko I, Absher D, Albrecht E, Ernst F, Glazer NL, Hayward C, Hottenga JJ, Jacobs KB, Knowles JW, Kutalik Z, Monda KL, Polasek O, Preuss M, Rayner NW, Robertson NR, Steinthorsdottir V, Tyrer JP, Voight BF, Wiklund F, Xu J, Zhao JH, Nyholt DR, Pellikka N, Perola M, Perry JR, Surakka I, Tammesoo ML, Altmaier EL, Amin N, Aspelund T, Bhangale T, Boucher G, Chasman DI, Chen C, Coin L, Cooper MN, Dixon AL, Gibson Q, Grundberg E, Hao K, Juhani Junttila M, Kaplan LM, Kettunen J, Konig IR, Kwan T, Lawrence RW, Levinson DF, Lorentzon M, McKnight B, Morris AP, Muller M, Suh Ngwa J, Purcell S, Rafelt S, Salem RM, Salvi E, Sanna S, Shi J, Sovio U, Thompson JR, Turchin MC, Vandenput L, Verlaan DJ, Vitart V, White CC, Ziegler A, Almgren P, Balmforth AJ, Campbell H, Citterio L, De Grandi A, Dominiczak A, Duan J, Elliott P, Elosua R, Eriksson JG, Freimer NB, Geus EJ, Glorioso N, Haiqing S, Hartikainen AL, Havulinna AS, Hicks AA, Hui J, Igl W, Illig T, Jula A, Kajantie E, Kilpelainen TO, Koiranen M, Kolcic I, Koskinen S, Kovacs P, Laitinen J, Liu J, Lokki ML, Marusic A, Maschio A, Meitinger T, Mulas A, Pare G, Parker AN, Peden JF, Petersmann A, Pichler I, Pietilainen KH, Pouta A, Ridderstrale M, Rotter JI, Sambrook JG, Sanders AR, Schmidt CO, Sinisalo J, Smit JH, Stringham HM, Bragi Walters G, Widen E, Wild SH, Willemsen G, Zagato L, Zgaga L, Zitting 
P, Alavere H, Farrall M, McArdle WL, Nelis M, Peters MJ, Ripatti S, van Meurs JB, Aben KK, Ardlie KG, Beckmann JS, Beilby JP, Bergman RN, Bergmann S, Collins FS, Cusi D, den Heijer M, Eiriksdottir G, Gejman PV, Hall AS, Hamsten A, Huikuri HV, Iribarren C, Kahonen M, Kaprio J, Kathiresan S, Kiemeney L, Kocher T, Launer LJ, Lehtimaki T, Melander O, Mosley TH Jr, Musk AW, Nieminen MS, O'Donnell CJ, Ohlsson C, Oostra B, Palmer LJ, Raitakari O, Ridker PM, Rioux JD, Rissanen A, Rivolta C, Schunkert H, Shuldiner AR, Siscovick DS, Stumvoll M, Tonjes A, Tuomilehto J, van Ommen GJ, Viikari J, Heath AC, Martin NG, Montgomery GW, Province MA, Kayser M, Arnold AM, Atwood LD, Boerwinkle E, Chanock SJ, Deloukas P, Gieger C, Gronberg H, Hall P, Hattersley AT, Hengstenberg C, Hoffman W, Lathrop GM, Salomaa V, Schreiber S, Uda M, Waterworth D, Wright AF, Assimes TL, Barroso I, Hofman A, Mohlke KL, Boomsma DI, Caulfield MJ, Cupples LA, Erdmann J, Fox CS, Gudnason V, Gyllensten U, Harris TB, Hayes RB, Jarvelin MR, Mooser V, Munroe PB, Ouwehand WH, Penninx BW, Pramstaller PP, Quertermous T, Rudan I, Samani NJ, Spector TD, Volzke H, Watkins H, Wilson JF, Groop LC, Haritunians T, Hu FB, Kaplan RC, Metspalu A, North KE, Schlessinger D, Wareham NJ, Hunter DJ, O'Connell JR, Strachan DP, Wichmann HE, Borecki IB, van Duijn CM, Schadt EE, Thorsteinsdottir U, Peltonen L, Uitterlinden AG, Visscher PM, Chatterjee N, Loos RJ, Boehnke M, McCarthy MI, Ingelsson E, Lindgren CM, Abecasis GR, Stefansson K, Frayling TM, Hirschhorn JN. Hundreds of variants clustered in genomic loci and biological pathways affect human height. Nature. 2010; 467:832-838. [PubMed: 20881960]

123. Gordon DJ, Probstfield JL, Garrison RJ, Neaton JD, Castelli WP, Knoke JD, Jacobs DR Jr, Bangdiwala S, Tyroler HA. High-density lipoprotein cholesterol and cardiovascular disease. Four prospective American studies. Circulation. 1989; 79:8-15. [PubMed: 2642759]

124. Di Angelantonio E, Sarwar N, Perry P, Kaptoge S, Ray KK, Thompson A, Wood AM, Lewington S, Sattar N, Packard CJ, Collins R, Thompson SG, Danesh J. Major lipids, apolipoproteins, and risk of vascular disease. JAMA : the journal of the American Medical Association. 2009; 302:1993-2000. [PubMed: 19903920]

125. Sarwar N, Danesh J, Eiriksdottir G, Sigurdsson G, Wareham N, Bingham S, Boekholdt SM, Khaw KT, Gudnason V. Triglycerides and the risk of coronary heart disease: 10,158 incident cases among 262,525 participants in 29 Western prospective studies. Circulation. 2007; 115:450458. [PubMed: 17190864]

126. Ye R, Scherer PE. Adiponectin, driver or passenger on the road to insulin sensitivity? Molecular metabolism. 2013; 2:133-141. [PubMed: 24049728]

127. Digby JE, Martinez F, Jefferson A, Ruparelia N, Chai J, Wamil M, Greaves DR, Choudhury RP. Anti-inflammatory effects of nicotinic acid in human monocytes are mediated by GPR109A dependent mechanisms. Arteriosclerosis, thrombosis, and vascular biology. 2012; 32:669-676.

128. Ory V, Fan Q, Hamdaoui N, Zhang SY, Desvaux D, Audard V, Candelier M, Noel LH, Lang P, Guellaen G, Pawlak A, Sahali D. c-mip down-regulates NF-kappaB activity and promotes apoptosis in podocytes. The American journal of pathology. 2012; 180:2284-2292. [PubMed: 22507836]

129. Kitchener RL, Grunden AM. Prolidase function in proline metabolism and its medical and biotechnological applications. Journal of applied microbiology. 2012; 113:233-247. [PubMed: 22512465]

130. Duong HS, Zhang QZ, Le AD, Kelly AP, Kamdar R, Messadi DV. Elevated prolidase activity in keloids: correlation with type I collagen turnover. The British journal of dermatology. 2006; 154:820-828. [PubMed: 16634881]

131. Vaquerizas JM, Kummerfeld SK, Teichmann SA, Luscombe NM. A census of human transcription factors: function, expression and evolution. Nature reviews. Genetics. 2009; 10:252-263.

132. Freathy RM, Timpson NJ, Lawlor DA, Pouta A, Ben-Shlomo Y, Ruokonen A, Ebrahim S, Shields B, Zeggini E, Weedon MN, Lindgren CM, Lango H, Melzer D, Ferrucci L, Paolisso G, Neville MJ, Karpe F, Palmer CN, Morris AD, Elliott P, Jarvelin MR, Smith GD, McCarthy MI, Hattersley AT, Frayling TM. Common variation in the FTO gene alters diabetes-related metabolic traits to the extent expected given its effect on. BMI Diabetes. 2008; 57:1419-1426. 
133. Fall T, Hagg S, Magi R, Ploner A, Fischer K, Horikoshi M, Sarin AP, Thorleifsson G, Ladenvall C, Kals M, Kuningas M, Draisma HH, Ried JS, van Zuydam NR, Huikari V, Mangino M, Sonestedt E, Benyamin B, Nelson CP, Rivera NV, Kristiansson K, Shen HY, Havulinna AS, Dehghan A, Donnelly LA, Kaakinen M, Nuotio ML, Robertson N, de Bruijn RF, Ikram MA, Amin N, Balmforth AJ, Braund PS, Doney AS, Doring A, Elliott P, Esko T, Franco OH, Gretarsdottir S, Hartikainen AL, Heikkila K, Herzig KH, Holm H, Hottenga JJ, Hypponen E, Illig T, Isaacs A, Isomaa B, Karssen LC, Kettunen J, Koenig W, Kuulasmaa K, Laatikainen T, Laitinen J, Lindgren C, Lyssenko V, Laara E, Rayner NW, Mannisto S, Pouta A, Rathmann W, Rivadeneira F, Ruokonen A, Savolainen MJ, Sijbrands EJ, Small KS, Smit JH, Steinthorsdottir V, Syvanen AC, Taanila A, Tobin MD, Uitterlinden AG, Willems SM, Willemsen G, Witteman J, Perola M, Evans A, Ferrieres J, Virtamo J, Kee F, Tregouet DA, Arveiler D, Amouyel P, Ferrario MM, Brambilla P, Hall AS, Heath AC, Madden PA, Martin NG, Montgomery GW, Whitfield JB, Jula A, Knekt P, Oostra B, van Duijn CM, Penninx BW, Davey Smith G, Kaprio J, Samani NJ, Gieger C, Peters A, Wichmann HE, Boomsma DI, de Geus EJ, Tuomi T, Power C, Hammond CJ, Spector TD, Lind L, Orho-Melander M, Palmer CN, Morris AD, Groop L, Jarvelin MR, Salomaa V, Vartiainen E, Hofman A, Ripatti S, Metspalu A, Thorsteinsdottir U, Stefansson K, Pedersen NL, McCarthy MI, Ingelsson E, Prokopenko I. The role of adiposity in cardiometabolic traits: a mendelian randomization analysis. PLoS Med. 2013; 10:e1001474. [PubMed: 23824655] 


\section{Highlights}

- Analyzed 17 metabolic and inflammatory traits in > 85,500 participants from 14 studies

- Big data evidenced that inflammation is a feature of metabolic syndrome (MetS)

- Performed meta-analyses of large GWAS for 8 metabolic and 6 inflammatory traits

- Of the 130 pleiotropic variants identified, 25 are proposed to contribute to MetS

- Pleiotropy across MetS risk factors reflects in its correlated genetic architecture 
b)

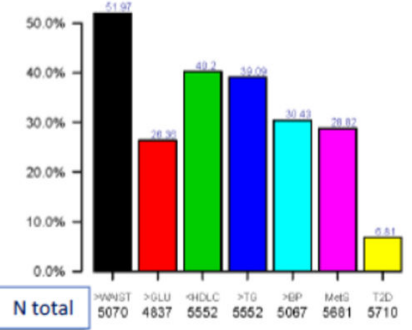

PAl1

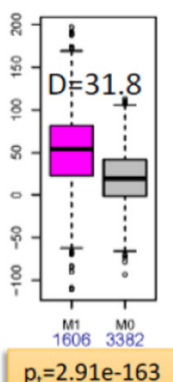

FamHS -EA

Prevalence of MetS and its components

CRP

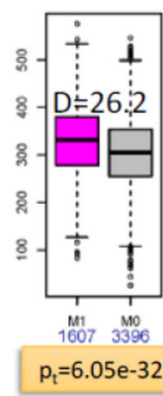

wBCC

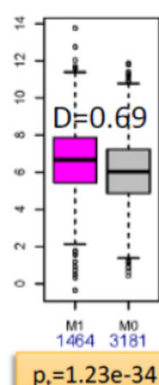

Mo

$p_{t}=1.23 e-34$

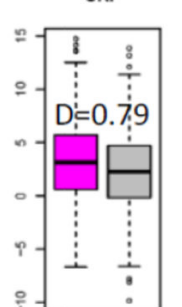
$\mathrm{p}_{\mathrm{t}}=1.61 \mathrm{e}-06$

Simulated $N(\mu, \sigma)$ based on Mean and STD of biomarker

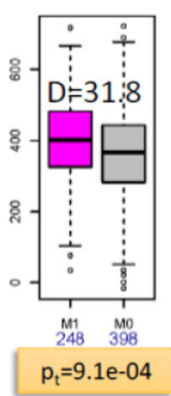

Figure 1.

Prevalence of MetS and its components and mean levels of inflammatory markers in individuals classified with and without $\operatorname{MetS}\left(\mathrm{M}_{1}\right.$ vs. $\left.\mathrm{M}_{0}\right)$.

Footnote: Top histogram numbers represent prevalence (\%) of MetS, T2D and MetS components. Bottom numbers represent number of participants for a particular trait. The inflammatory marker boxplot graph comparisons were built by using "rnorm" function in R with mean, standard deviation and sample size corresponding to subgroups with and without MetS from original (B) data. Overall, they represent 53 tests of inflammatory markers per MetS strata, summarized in Supplemental Figures 1(a-g). The number within each pair of boxplots marked by " $\mathrm{D}=$ " is the difference of two means of an inflammatory marker in groups of participants classified with versus without MetS. The light yellow boxed number at the bottom of the same graph marked with " $\mathrm{p}_{\mathrm{t}}=$ " represents a $\mathrm{p}$-value calculated by pooled $\mathrm{t}$-test for testing if their means $\left(\mathrm{M}_{1}\right.$ vs. $\left.\mathrm{M}_{0}\right)$ are different. In case the color of $\mathrm{p}_{\mathrm{t}}$-value box is gray, then the $\mathrm{p}$-value does not pass the Bonferroni threshold $\mathrm{p}=9.43 \mathrm{e}-04$. 


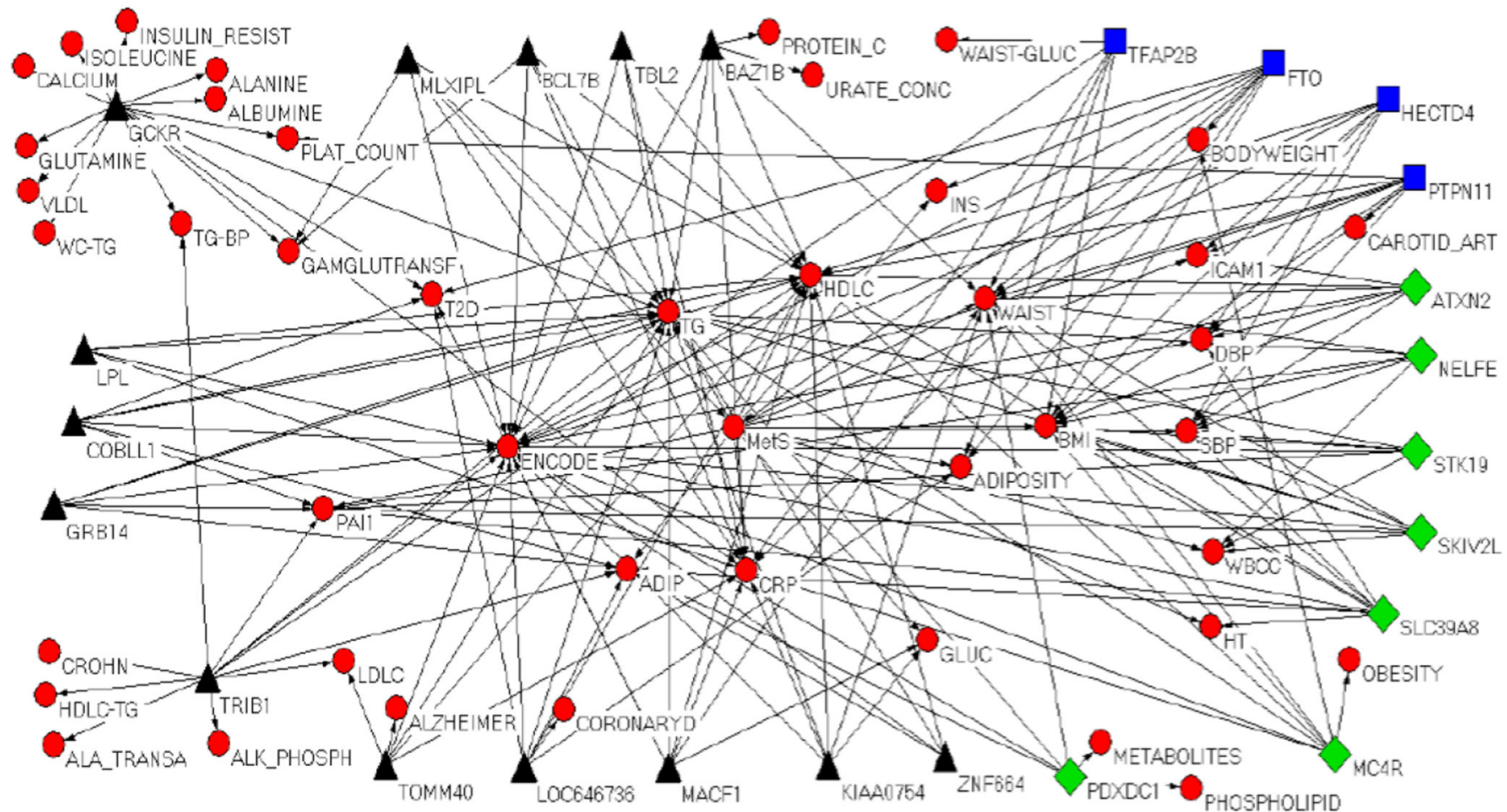

Figure 2.

A network of 25 pleiotropic genes with putative contributions to MetS, including inflammation.

Footnote: In the figure they connect by GWAS phenotypic evidence and whether selected SNPs show any regulatory features based on the ENCODE database as implemented via HaploReg [50]/RegulomeDB [51] software. All phenotypic labels correspond to associations reported in the Results, Discussion, Table 5 and Suppplemental Table 5. 


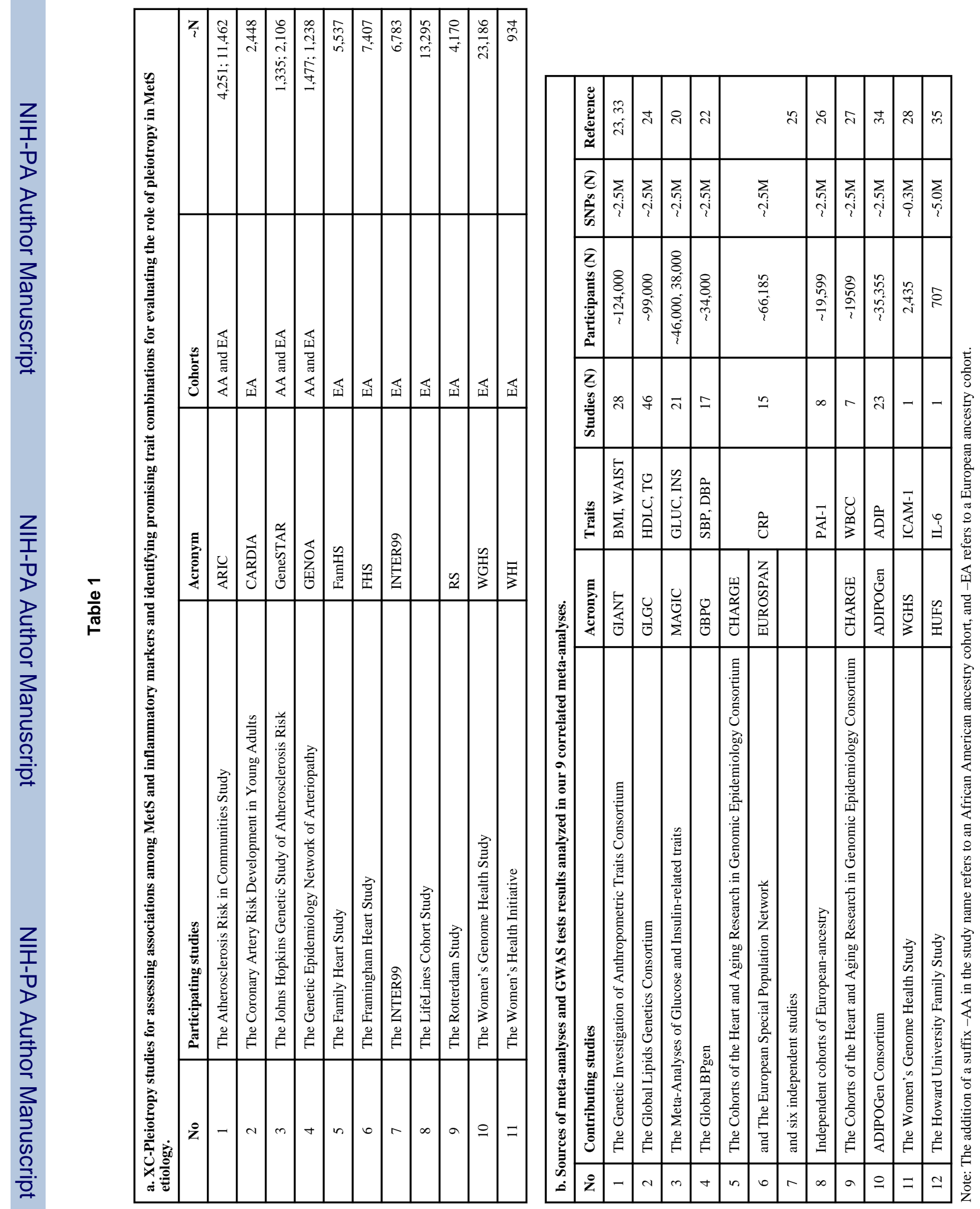




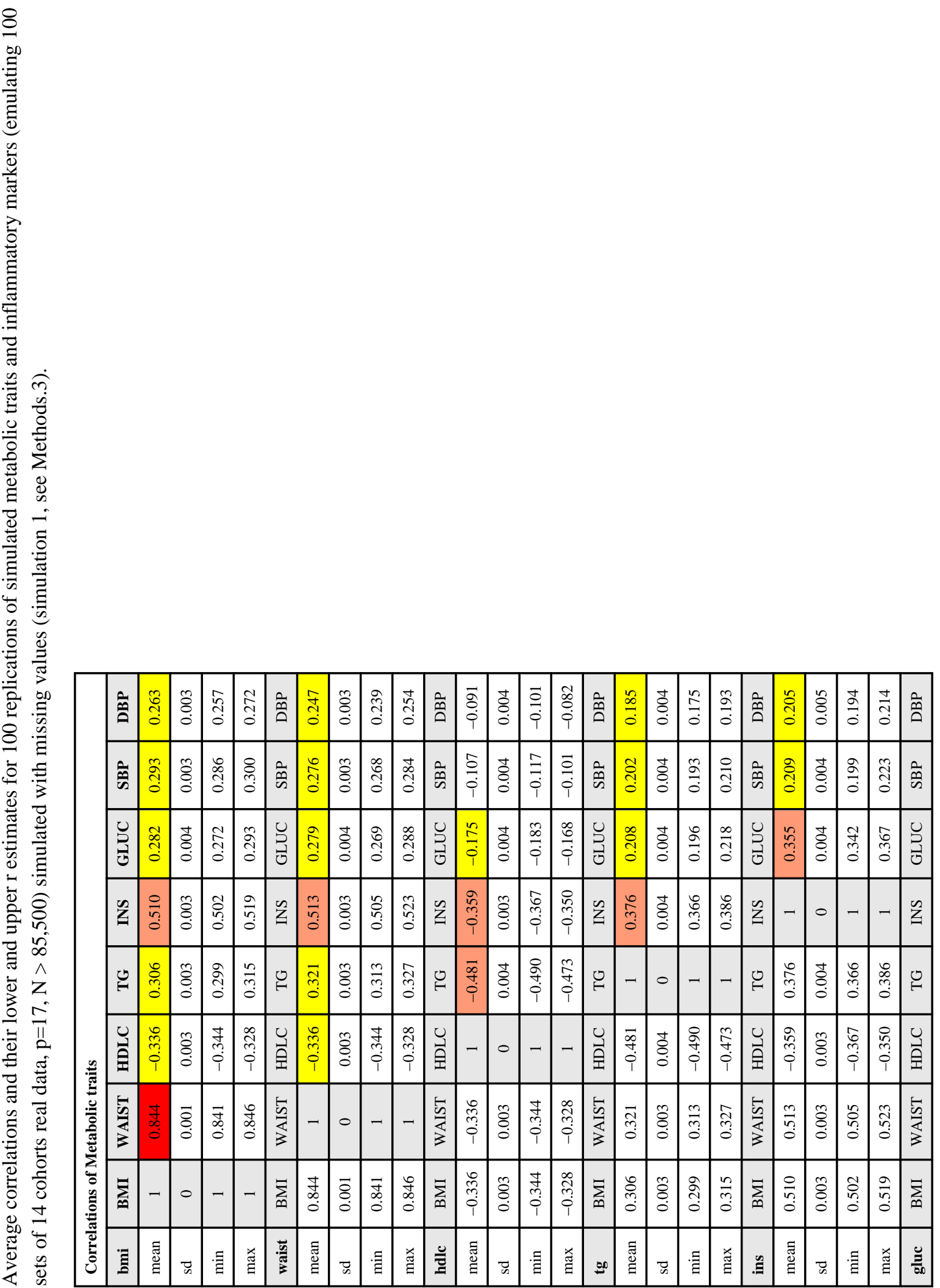




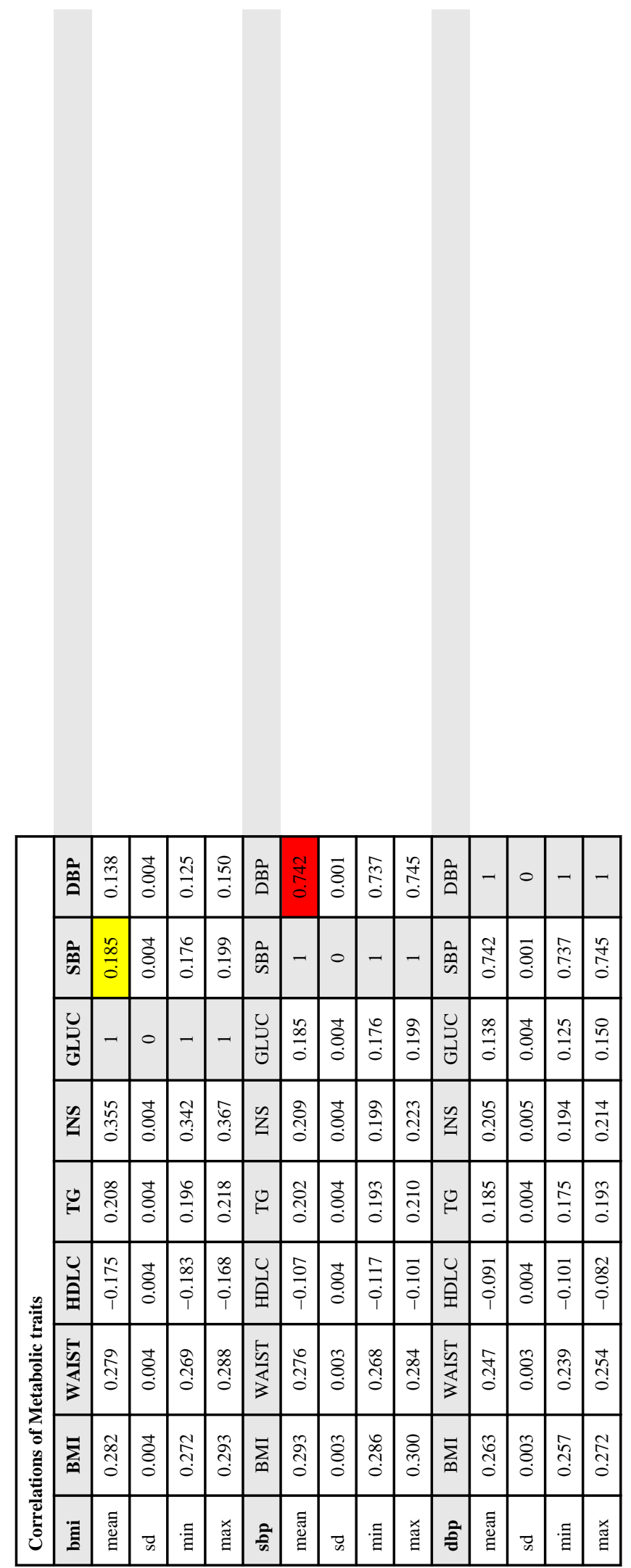

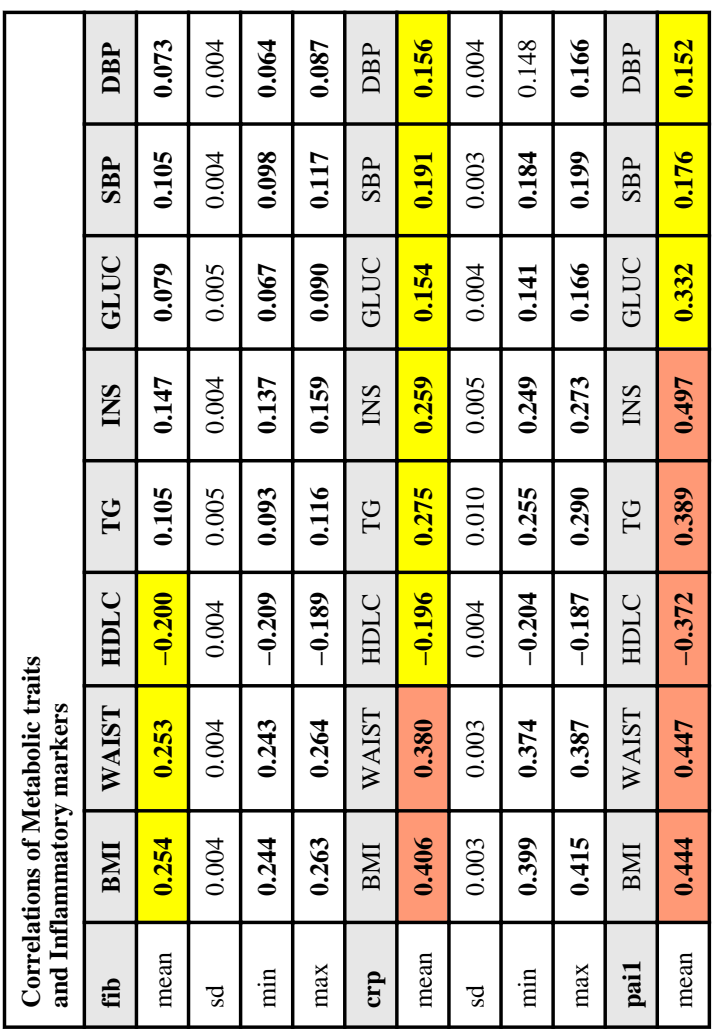




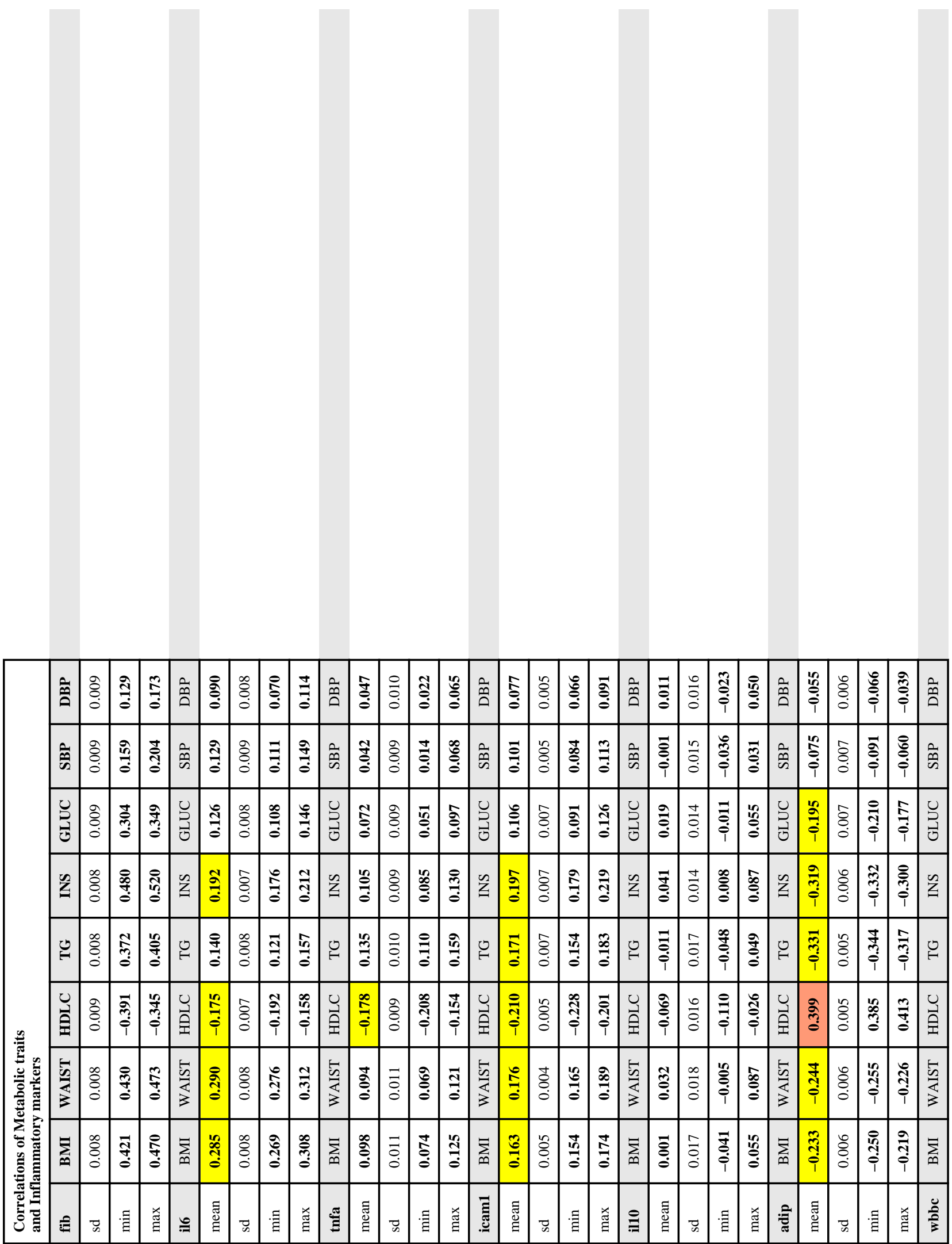




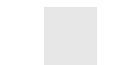

\begin{tabular}{|c|c|c|c|c|c|c|c|c|c|c|c|c|c|c|c|c|c|c|c|c|c|c|c|}
\hline & & & $\tilde{\delta}$ & 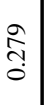 & 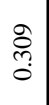 & $\begin{array}{l}0 \\
0 \\
\vdots \\
3\end{array}$ & $\frac{\hat{m}}{\hat{\sigma}}$ & $\mid \begin{array}{l}0 \\
\vdots \\
0 \\
0\end{array}$ & ర్ల & लై & $\begin{array}{l}0 \\
0 \\
\infty \\
3\end{array}$ & $\frac{8}{\circ}$ & $\mid \begin{array}{l}\infty \\
0 \\
0 \\
0\end{array}$ & $\frac{\mathcal{J}}{0}$ & $\begin{array}{l}\infty \\
0 \\
0\end{array}$ & $\begin{array}{l}u \\
0 \\
\vdots \\
3\end{array}$ & 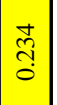 & $\begin{array}{l}n \\
0 \\
0 \\
0\end{array}$ & 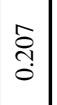 & $\left|\begin{array}{c}0 \\
\multirow{2}{0}{} \\
0 \\
0\end{array}\right|$ & $\begin{array}{l}u \\
\text { D } \\
3\end{array}$ & $\begin{array}{l}\infty \\
\stackrel{\infty}{0} \\
0 \\
0\end{array}$ & 吕 \\
\hline & & & $\begin{array}{l}\text { ठे. } \\
\text { ¿े }\end{array}$ & $\begin{array}{c}\text { 卞 } \\
\\
\end{array}$ & $\begin{array}{l}\widetilde{\delta} \\
\stackrel{0}{i} \\
\stackrel{1}{0}\end{array}$ & 言 & 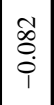 & \begin{tabular}{l}
$\vdots$ \\
$\vdots$ \\
\hdashline
\end{tabular} & 帢 & $\begin{array}{l}\text { to } \\
\\
0\end{array}$ & 言 & $\begin{array}{l}\tilde{n} \\
\tilde{i} \\
\hat{1}\end{array}$ & $\begin{array}{l} \pm \\
\stackrel{0}{0}\end{array}$ & 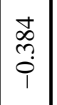 & 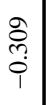 & 言 & \begin{tabular}{|l|}
0 \\
0 \\
0 \\
$i$
\end{tabular} & 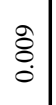 & $\begin{array}{l}n \\
n \\
n \\
i\end{array}$ & $\begin{array}{l}0 \\
\cong \\
\\
\end{array}$ & 言 & $\begin{array}{l}: \\
: \\
\dot{1}\end{array}$ & $\stackrel{0}{\circ}$ \\
\hline & & & $\begin{array}{l}\frac{\pi}{0} \\
0 \\
0\end{array}$ & : & $\frac{\text { v }}{0}$ & $\stackrel{\varrho}{\stackrel{\exists}{\exists}}$ & 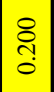 & $\begin{array}{l}n \\
\vdots \\
0 \\
0\end{array}$ & $\tilde{n}$ & तે & $\stackrel{\circ}{\exists}$ & $\begin{array}{l}8 \\
\stackrel{0}{0} \\
0\end{array}$ & $\begin{array}{l}\tilde{0} \\
0 \\
0\end{array}$ & $\begin{array}{l}\tilde{Z} \\
\delta \\
0\end{array}$ & $\vec{\beth}$ & $\stackrel{\varrho}{\exists}$ & & & & & $\stackrel{\circ}{\stackrel{\exists}{\exists}}$ & $\begin{array}{l}\hat{a} \\
\dot{o}\end{array}$ & $\frac{n}{0}$ \\
\hline & & & 苂 & $\stackrel{े}{\mathrm{~N}}$ & ָે & $\mid \begin{array}{l}\bar{\sum} \\
0 \\
0\end{array}$ & $\mid$\begin{tabular}{l}
0 \\
\multirow{1}{0}{} \\
0
\end{tabular} & $\begin{array}{l} \\
0 \\
0 \\
0\end{array}$ & & 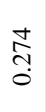 & $\mid \begin{array}{l}\bar{z} \\
0 \\
0\end{array}$ & 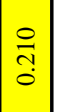 & $\stackrel{0}{\circ}$ & $\left.\mid \begin{array}{c}\infty \\
0 \\
0\end{array}\right]$ & 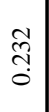 & $\left|\begin{array}{l}\bar{z} \\
0 \\
0\end{array}\right|$ & 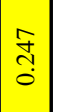 & \begin{tabular}{|l|}
0 \\
0 \\
0
\end{tabular} & $\begin{array}{l}\text { तె } \\
0\end{array}$ & 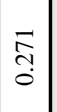 & $\begin{array}{l}\sum_{0} \\
\underline{\underline{U}}\end{array}$ & గ్t & ठे. \\
\hline & & & ठ̊. & $\begin{array}{l}n \\
\vdots \\
0 \\
0\end{array}$ & $\stackrel{\vartheta}{0}$ & 离 & 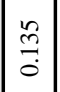 & $\begin{array}{l}\circ \\
0 \\
0\end{array}$ & & $\frac{n}{0}$ & $\mid \begin{array}{l}\mathbb{1} \\
\sum_{i}\end{array}$ & $\frac{8}{0}$ & $\stackrel{\Xi}{0}$ & $\frac{\vartheta}{\Im}$ & 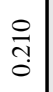 & 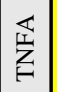 & 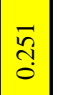 & $\mid \begin{array}{l}\vec{z} \\
0 \\
0\end{array}$ & 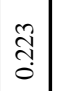 & 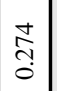 & 至 & -1 & 0 \\
\hline & & & $\begin{array}{l}5 \\
\delta \\
0\end{array}$ & $\begin{array}{c}\vec{m} \\
0 \\
0\end{array}$ & 告 & $\stackrel{\wp}{=}$ & $\left|\begin{array}{l}0 \\
7 \\
\dot{J}\end{array}\right|$ & $\begin{array}{l}\infty \\
\vdots \\
0 \\
0\end{array}$ & 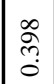 & $\stackrel{\text { }}{\stackrel{f}{f}}$ & $\stackrel{0}{=}$ & $\frac{\bar{J}}{\partial}$ & 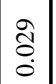 & $\mid \begin{array}{l}2 \\
0 \\
0 \\
0\end{array}$ & $\begin{array}{l}\text { ָे } \\
\text { ธิ }\end{array}$ & $\stackrel{0}{=}$ & -1 & 0 & -1 & -1 & $\stackrel{0}{\varrho}$ & $\begin{array}{l}\overrightarrow{\tilde{n}} \\
0 \\
0\end{array}$ & $\overrightarrow{0}$ \\
\hline & & & $\begin{array}{l}\circ \\
\stackrel{0}{0} \\
0\end{array}$ & $\begin{array}{l}\text { đ్ } \\
\stackrel{7}{0}\end{array}$ & $\stackrel{5}{=}$ & $\exists$ & $\mid$\begin{tabular}{|c|}
$\infty$ \\
\multirow{2}{0}{} \\
0
\end{tabular} & $\mid \begin{array}{l}\infty \\
0 \\
0 \\
0\end{array}$ & 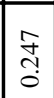 & 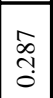 & $\mid \begin{array}{l}z \\
\Sigma\end{array}$ & - & 0 & - & -1 & $\begin{array}{l}\bar{\alpha} \\
\Omega\end{array}$ & \begin{tabular}{|l}
$\exists$ \\
0
\end{tabular} & 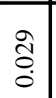 & $\left|\begin{array}{l}0 \\
0 \\
0 \\
0\end{array}\right|$ & $\begin{array}{l}\text { त̂̀ } \\
\text { ô }\end{array}$ & $\bar{\Xi}$ & $\frac{8}{0}$ & 官 \\
\hline & & & $\begin{array}{l}\text { 总 } \\
0 \\
0\end{array}$ & 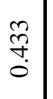 & 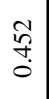 & $\approx$ & - & o & - & - & $\overrightarrow{\widetilde{\Xi}}$ & $\mid$\begin{tabular}{l}
$\infty$ \\
\multirow{0}{0}{} \\
0 \\
0
\end{tabular} & $\mid \begin{array}{l}\infty \\
0 \\
0 \\
0\end{array}$ & 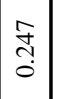 & 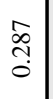 & ชิ & \begin{tabular}{l}
0 \\
\multirow{0}{*}{} \\
0
\end{tabular} & $\begin{array}{l}\infty \\
0 \\
0 \\
0\end{array}$ & 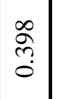 & $\begin{array}{c}\stackrel{\Im}{f} \\
\stackrel{\sigma}{\sigma}\end{array}$ & $\vec{\approx}$ & $\begin{array}{l}\stackrel{m}{0} \\
0\end{array}$ & $\stackrel{\overrightarrow{0}}{\circ}$ \\
\hline & & & 0 & - & - & $\cong$ & 导 & 苛 & శ్ & 话 & 自 & $\begin{array}{l}0 \\
0 \\
0\end{array}$ & $\begin{array}{l}0 \\
0 \\
0\end{array}$ & $\begin{array}{l}\infty \\
\stackrel{1}{0} \\
0\end{array}$ & $\begin{array}{c}\vec{E} \\
0\end{array}$ & 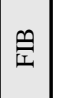 & $\begin{array}{c}\vec{m} \\
\stackrel{0}{0}\end{array}$ & 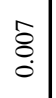 & $\frac{\tilde{m}}{0}$ & $\begin{array}{c}\tilde{f} \\
\mathrm{~J} \\
0\end{array}$ & $\stackrel{\oplus}{1}$ & $\begin{array}{l}\overrightarrow{0} \\
0 \\
0\end{array}$ & छे \\
\hline & & & $\vec{n}$ & 春 & $\underset{\Xi}{\stackrel{\varpi}{\Xi}}$ & $\bar{c}$ & త్ & $\bar{s}$ & & $\Xi$ & $\overline{\tilde{\Xi}}$ & ఫ్ & $\vec{\phi}$ & 春 & $\exists$ & $\cong$ & $\stackrel{\Xi}{\Xi}$ & च & 吾 & 剪 & $\stackrel{\Xi}{\Xi}$ & $\stackrel{\circlearrowright}{\Xi}$ & $\ldots$ \\
\hline
\end{tabular}




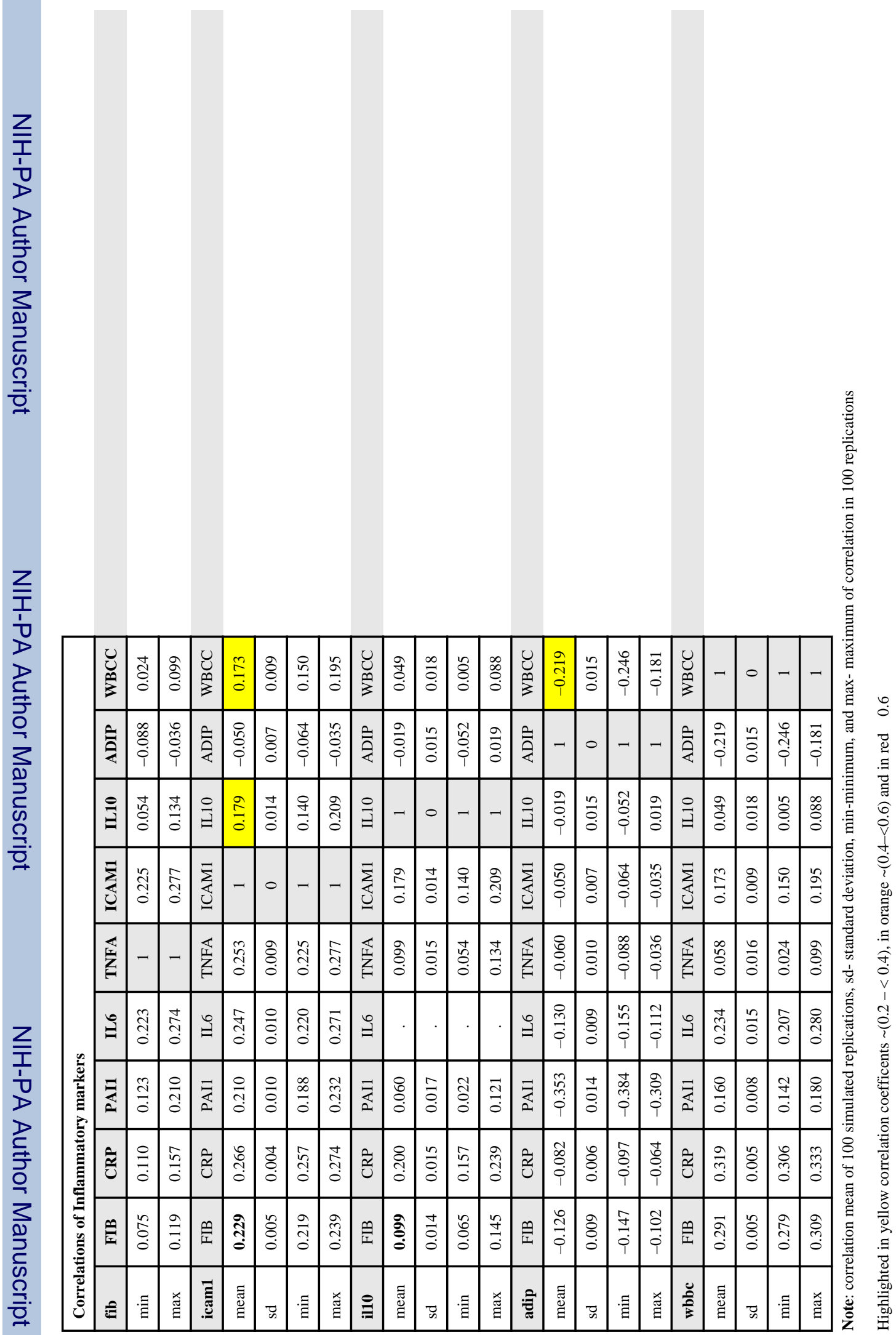




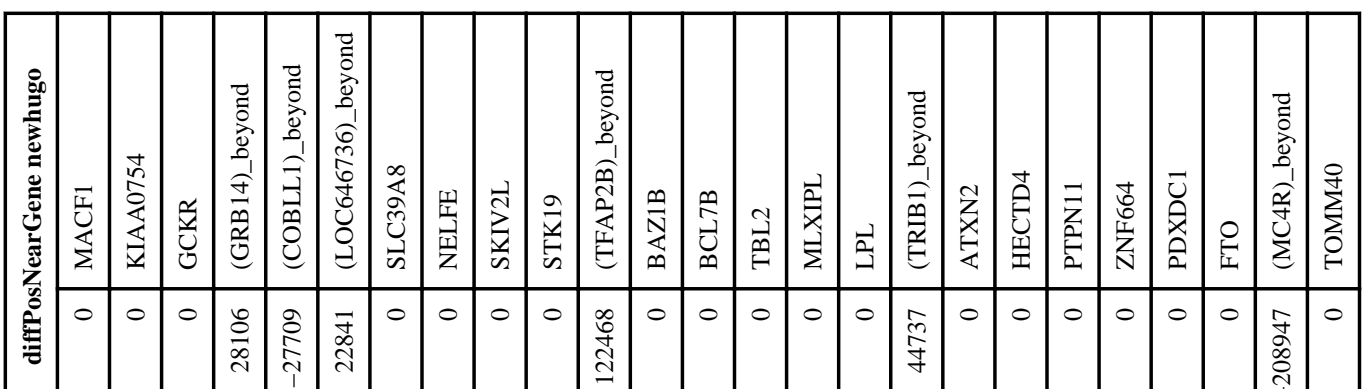

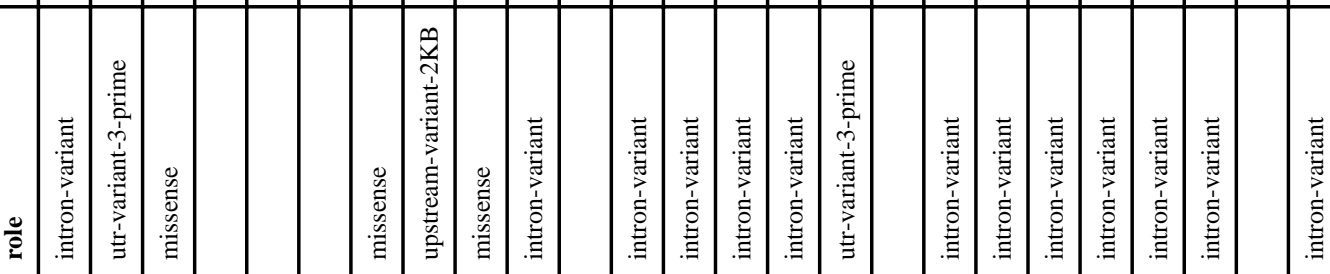

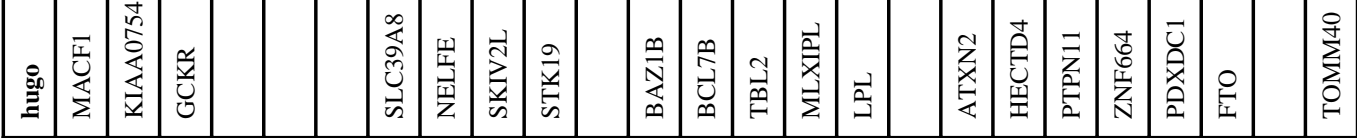

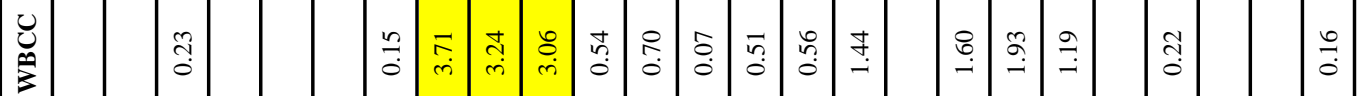

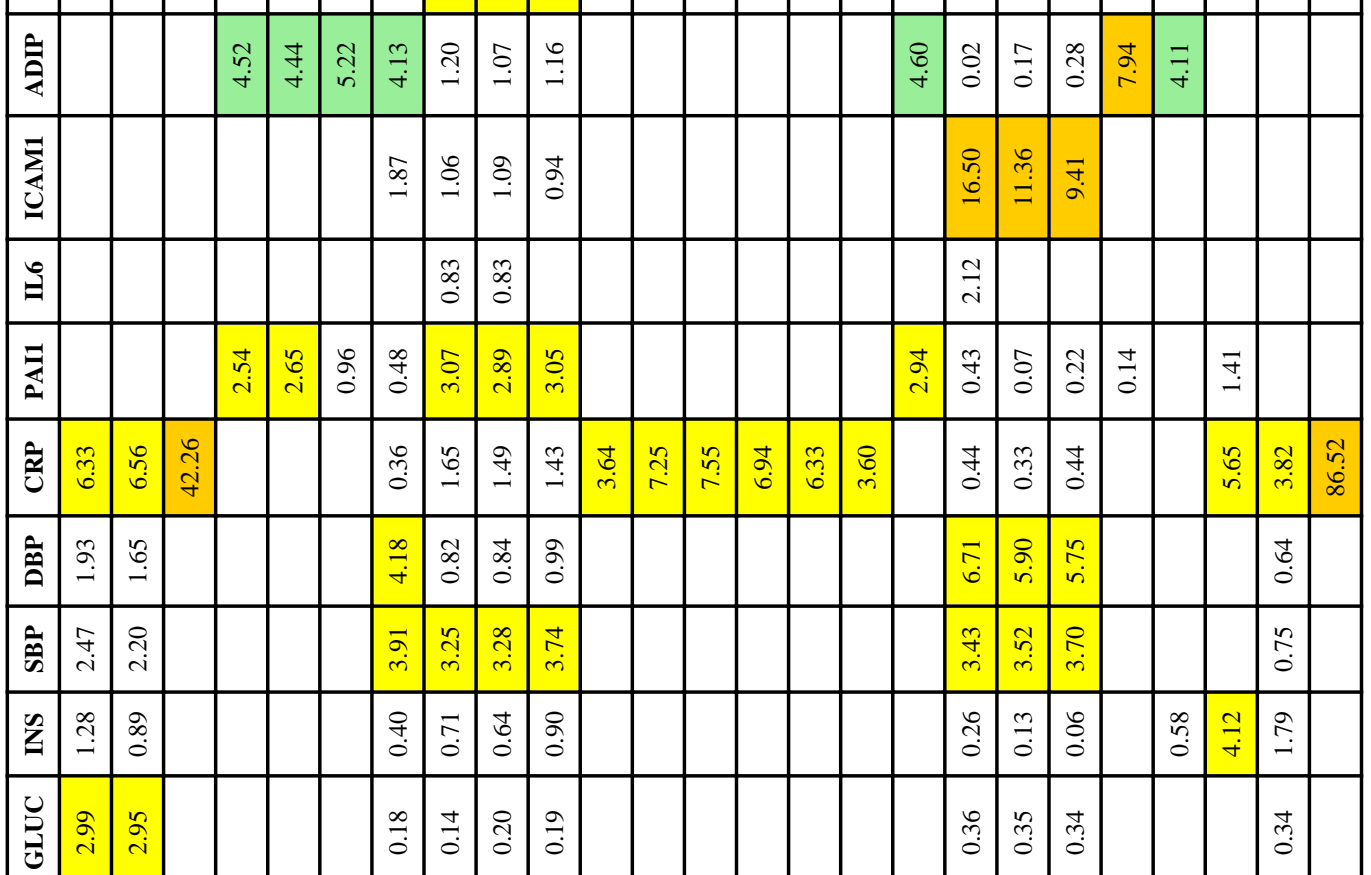

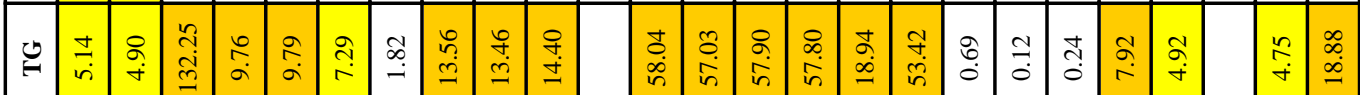

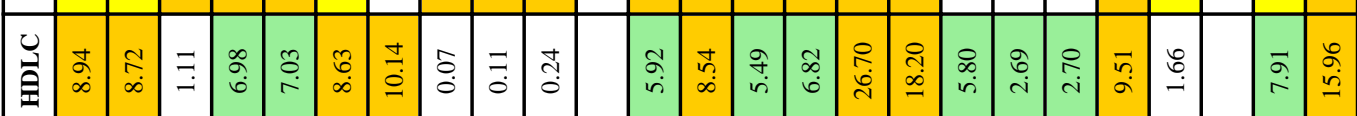

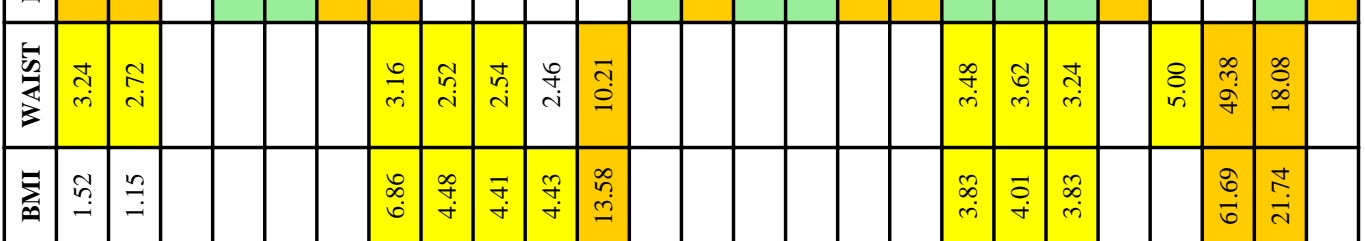

:

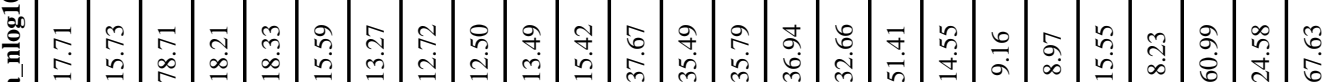
焉

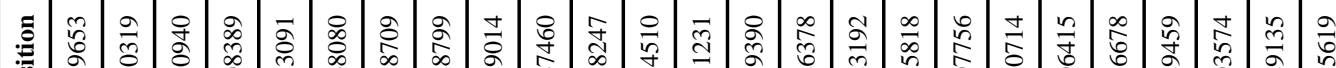

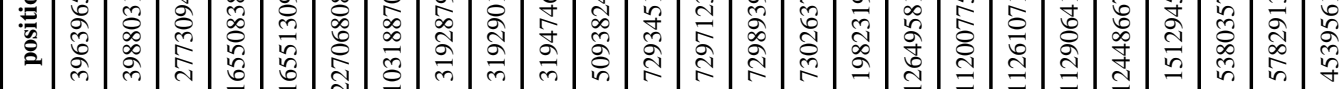
产

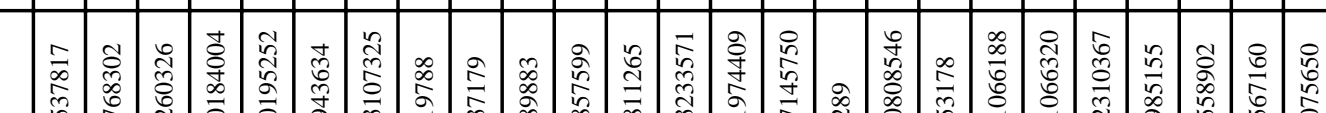

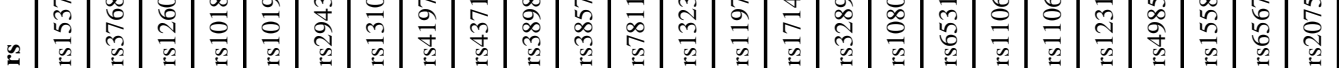
5 Mol Gepet ne

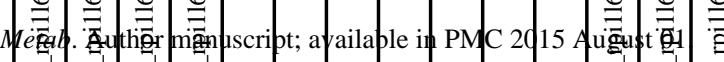

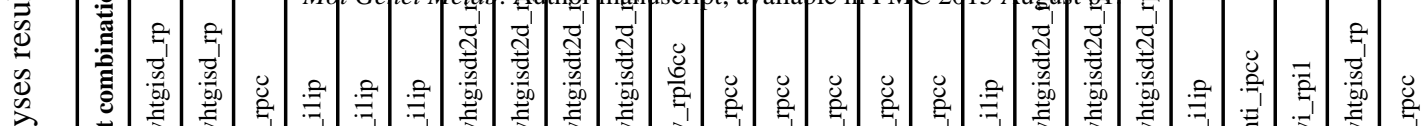

焉 
产 总

!n:

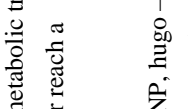




\begin{tabular}{|c|c|c|c|c|c|c|c|c|c|c|c|c|c|c|c|c|c|c|c|}
\hline 館 & & 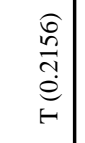 & 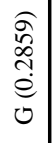 & $\begin{array}{l}\widehat{\hat{\delta}} \\
\text { ले } \\
\stackrel{e}{e} \\
\stackrel{H}{-}\end{array}$ & 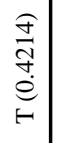 & 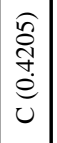 & 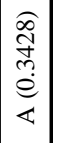 & $\begin{array}{l}\vec{a} \\
\stackrel{0}{0} \\
0\end{array}$ & 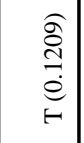 & $\begin{array}{l}0 \\
\vdots \\
\vdots \\
0 \\
0 \\
0\end{array}$ & 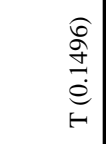 & 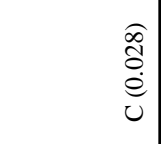 & 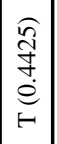 & 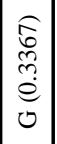 & 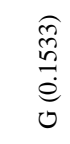 & & 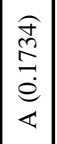 & $\begin{array}{l}\widehat{\hat{n}} \\
\vec{f} \\
e \\
e \\
<\end{array}$ & 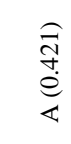 \\
\hline 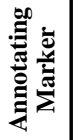 & & 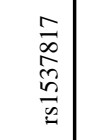 & 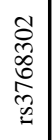 & 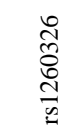 & 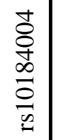 & 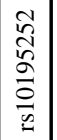 & 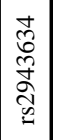 & 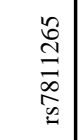 & $\begin{array}{l}\vec{n} \\
\tilde{n} \\
\tilde{n} \\
\vec{n}\end{array}$ & 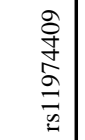 & 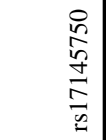 & $\begin{array}{l}\mathscr{\partial} \\
\text { Dె. }\end{array}$ & $\begin{array}{l}0 \\
4 \\
0 \\
0 \\
0 \\
0 \\
0 \\
0\end{array}$ & 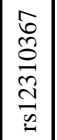 & 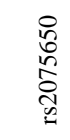 & & 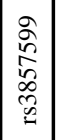 & $\begin{array}{l}\infty \\
\infty \\
\stackrel{0}{0} \\
\stackrel{0}{0} \\
\frac{0}{\square}\end{array}$ & 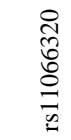 \\
\hline 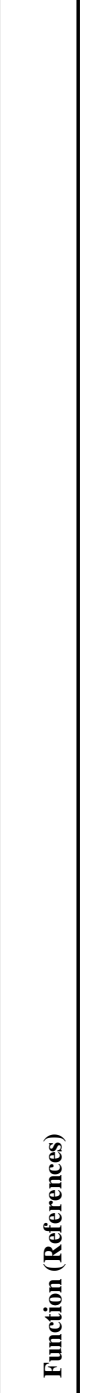 & 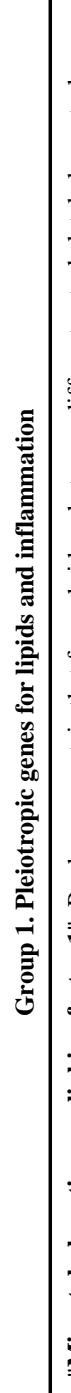 & 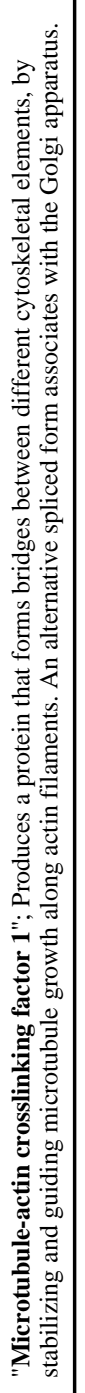 & 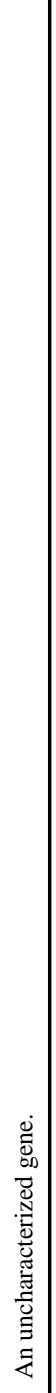 & 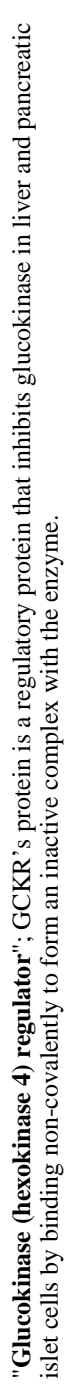 & 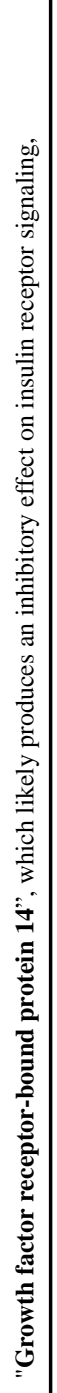 & 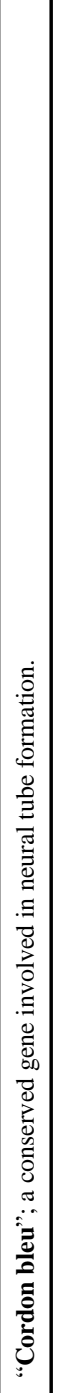 & 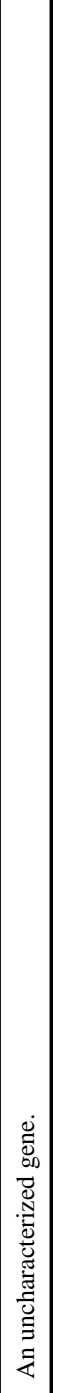 & 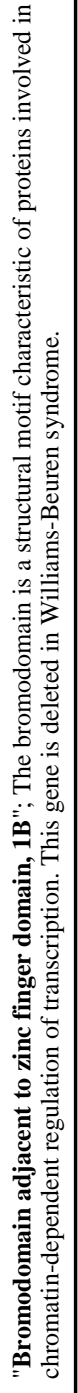 & 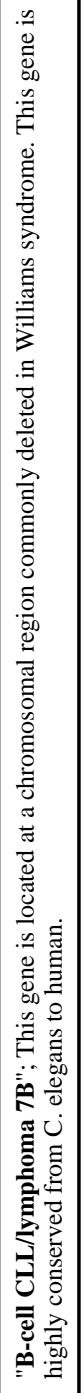 & 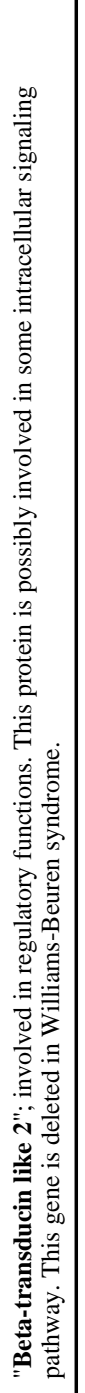 & 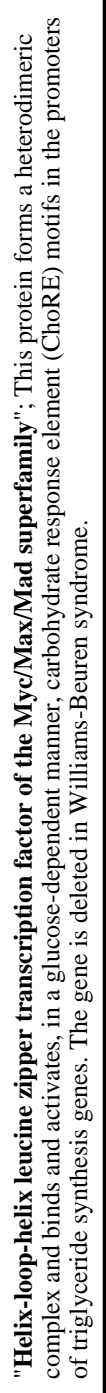 & 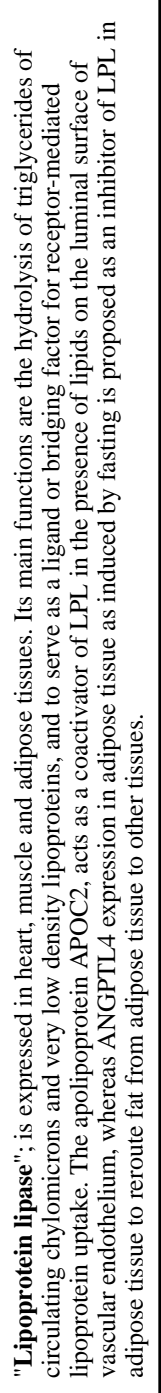 & 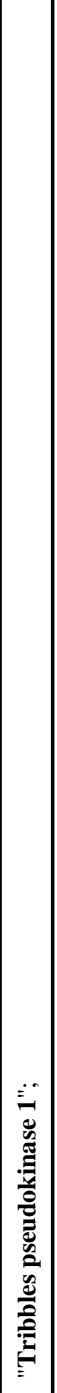 & 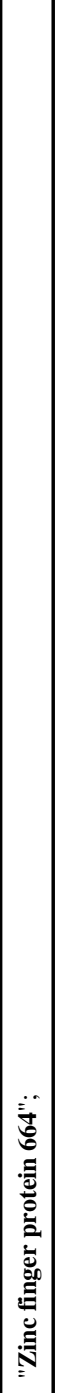 & 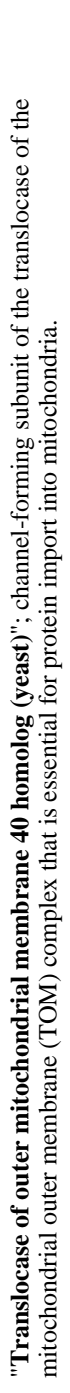 & 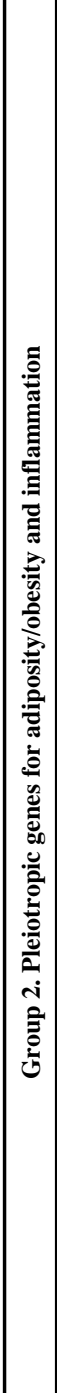 & 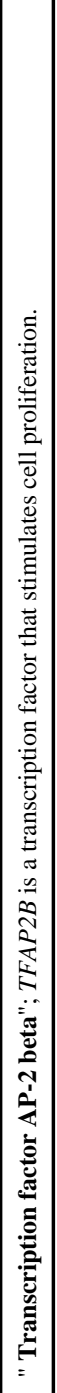 & 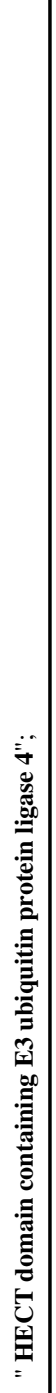 & 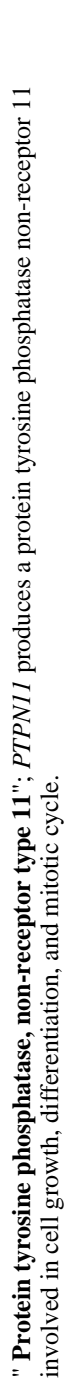 \\
\hline 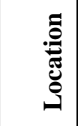 & & $\begin{array}{l}\text { ले } \\
\hat{i} \\
\hat{N} \\
\stackrel{3}{=}\end{array}$ & $\begin{array}{l}m \\
\stackrel{2}{2} \\
\stackrel{=}{\varrho}\end{array}$ & ते & 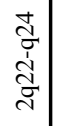 & 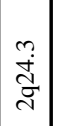 & 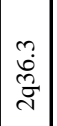 & $\begin{array}{l}\stackrel{\Im}{\mathfrak{Z}} \\
\bar{\Xi}\end{array}$ & 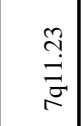 & 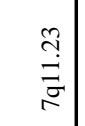 & $\therefore$ & $\tilde{\infty}$ & 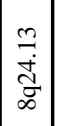 & $\mid$\begin{tabular}{|l}
$\vec{m}$ \\
$\dot{Z}$ \\
$\vec{\Xi}$ \\
$\mathbb{I}$
\end{tabular} & $\bar{\sigma}$ & & $\frac{1}{3}$ & 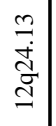 & \\
\hline كّ & & $\begin{array}{l}\mathbb{U} \\
\mathbb{Z}\end{array}$ & 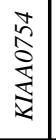 & 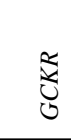 & 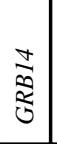 & $\mid$ & 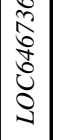 & $\vec{x}$ & $\overrightarrow{0}$ & 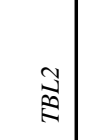 & $\Xi$ & $\Xi$ & $\approx$ & 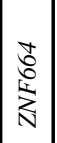 & $\overbrace{2}^{\frac{7}{2}}$ & & 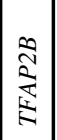 & $\begin{array}{l}\text { E } \\
\text { d } \\
0\end{array}$ & $\bar{\Sigma}$ \\
\hline 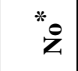 & & - & $\sim$ & $m$ & + & $n$ & 6 & -1 & $\rightarrow$ & -1 & -1 & $\stackrel{0}{-}$ & $=$ & $\vec{\sim}$ & ते & & $=$ & 2 & $\bar{N}$ \\
\hline
\end{tabular}




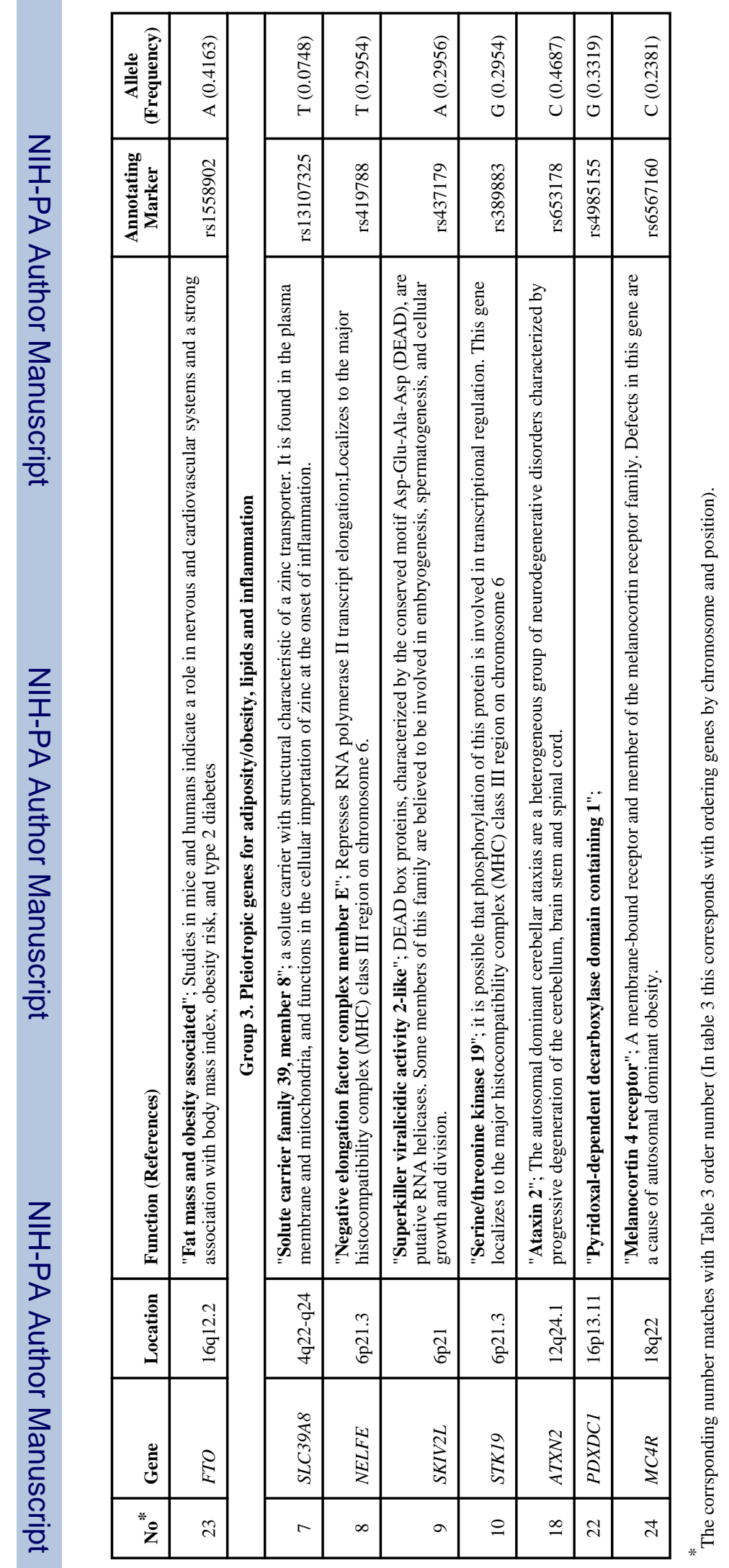

Mol Genet Metab. Author manuscript; available in PMC 2015 August 01. 
Table 5

A short summary of additional supportive findings for the 25 MetS pleiotropic candidates

Group 1: Pleiotropic genes for lipids and inflammatory markers

- The MACF1 was also associated with T2D (Albrechtsen et al., 2013). Recently, Fassett et al. (2013) using inducible cardiac-specific MCF1 knockout mice concluded this gene works as a stress induced regulator of cardiomyocyte microtubule distribution and is important for ventricular adaptation to hemodynamic overload. - The GCKR rs1260326 was associated with T2D risk, by changing the ability of $G C K R$ to sequester glucokinase in the nucleus of hepatocytes (Rees et al., 2012), and with hepatic fat accumulation along large VLDL and TG levels in obese youth (Santoro et al., 2013). Rees et al., 2012), suggested that leucine allele elevates hepatic glucose uptake and disposal by increasing active cytosolic GCK, which would increase hepatic lipid biosynthesis. Another GCKR SNP was associated with serum albumin (Kim et al., 2012), decreased levels of amino acids alanine and isoleucine and elevated levels of glutamine (Stancakova et al., 2012), with liver enzyme gamma-Glutamyltrasferase (Chambers et al., 2011), and platelet count (Gieger et al., 2011). GCKR was associated with serum calcium (O'Seaghdha et al., 2013). GCKR has already been proposed as a candidate for MetS for its significant associations with qualitative bivariate TG-BP and WC-TG (Kraja et al., 2011). The rs2303369, neighboring GCKR and an intron of fibronectin type III (FNDC4) was associated significantly with menopause (Stalk et al., 2012). • The $\boldsymbol{G R B 1 4}$ protein has a pleckstrin homology domain, a C-terminal Src homology 2 (SH2) domain, and an intervening $~ 45$ residues known as BPS. GRB14 and its family members GRB7 and GRB10 are recruited by a number of receptor tyrosine kinases (Depetris et al., 2005). This recruitment is facilitated via phosphotyrosine binding the SH2 domain, while the INS and IGF 1 receptors are recruited by the BPS region (Cariou et al., 2004). Cooney et al. (2004) noticed an improved glucose tolerance and an enhanced insulin-induced signaling in muscle and liver, but not in adipose tissue in a male mice deficient for Grb14 $\left(^{-/}\right)$. They proposed that Grb14 was a negative regulator, tissue specific for insulin signaling. In a gene expression study, Grb14 expression was elevated in adipose tissue of both ob/ob mice and Goto-Kakizaki (non-obese T2D) rats (Cariou et al., 2004). Our meta-analyses results add to the importance of $G R B 14$, which can be viewed as an inhibitor of the insulin receptor and therefore as affecting insulin signaling. - The $C O B L L 1$ (Carroll et al., 2003) was associated with T2D (Albrechtsen et al., 2013). Adjacent to this gene toward GRB14 are a number of SNPs that were associate with T2D (Kooner et al., 2011), TG (Teslovich et al., 2010) and HDLC (Teslovich et al.,2010). Albrechtsen et al. (2013) showed that COBLL1 expresses in pancreatic islets and kidney, and to some degree in skeletal muscle, liver and adipose tissue. They stipulated COBLL1 variants may influence expression of nearby GRB14 to change insulin sensitivity. • The $\mathbf{L O C 6 4 6 7 3 6}$ rs 2943634 was associated with coronary disease (Samani et al., 2007) and T2D (Rung et al., 2009). Downstream ( 47K bps) from this SNP, an intron of LOC646736 was associated with T2D (Voight et al., 2010). Upstream of our meta-SNP, a few SNPs associates with TG (Teslovich et al.,2010), with adiposity (Kilpelainen et al., 2011), and with ADIP (Dastani et al., 2012). • The $\boldsymbol{L P L}$ is significantly associated with TG and HDLC (Several studies confirm these associations). $L P L$ is part of glycerolipid metabolism pathway (map00561, kegg.jp), involved in free fatty acids production, and is also a member of PPAR signaling pathway (map03320, kegg.jp). • The TRIB1 is reported in associations with TG, HDLC, LDLC (Teslovich et al., 2010), with alkaline phosphatase and alanine transaminase (Chambers et al., 2011), with ADIP (Dastani et al., 2012), with Crohn's Disease (Barret et al., 2008), with bivariate qualitative combinations of HDLC-TG and TG-BP (Kraja et al., 2011). Recently Akira et al. (2013) working with Tribl $1^{(-)}$mice demonstrated that mice lacking Trib1 in hematopoietic cells exhibited severe lipodystrophy due to increased lipolysis, while in a high-fat diet, mice exhibited hypertriglyceridemia, insulin resistance, together with increased proinflammatory cytokine production. They suggested, that Tribl is critical for adipose tissue maintenance and suppression of metabolic disorders by controlling the differentiation of tissue-resident anti-inflammatory-like macrophages. The rs 10808546 positioned about $45 \mathrm{~K}$ bps from TRIB1 is located in a DNAase mark often found in active regulatory elements. - The ZNF664 associates with visceral adipose tissue adjusted for BMI and with visceral adipose tissue/subcutaneous adipose tissue ratio for women (Fox et al., 2012). - TOMM40 SNPs are in linkage disequilibrium with APOE SNPs (HapMap LD plot not shown). TOMM4O is positioned at the side of the cluster APOE/APOC4/APOC2 and was associated with Alzheimer's disease (Harold et al., 2013; Seshadri et al., 2010), low density lipoprotein cholesterol (LDLC) and HDLC (Aulchenko et al. 2009) and CRP (Aulchenko et al., 2009; Reiner et al., 2008). The rs2075650 of TOMM40 is part of three signatures of promoter histone marks, part of enhancer histone markers in 6 cell types, it can be involved in a DNase signature, and is part of 8 changed motifs, among them sterol regulatory element binding transcription factor (SREBP).

\section{Group2: Pleiotropic genes for adiposity/obesity and inflammation}

- An intron of $\boldsymbol{T F A P 2 B}$, was associated with the effects of dietary fat intake on weight loss and waist reduction (Stocks et al., 2012). A few other SNPs of TFAP2B associated significantly with BMI (Speliotes et al., 2010), adiposity (Lindgren et al., 2009) and with a qualitative bivariate WAIST-GLUC combination (Kraja et al., 2011). - The PTPN11 was associated with platelet counts (Soranzo et al., 2009), with TG (Kathiresan et al., 2007), and with carotid arteries (O'Donnell et al., 2007). • While FTO contributes to the regulation of the global metabolic rate, energy expenditure, energy homeostasis, regulation of body size and body fat accumulation, its exact function is not known. Other SNPs of FTO were associated with BMI (Sepliotes et al., 2010), body weight (Thorleifson et al., 2009), adiposity (Kilpelainen et al., 2011), WAIST (Heard-Costa et al., 2009), with T2D (Zeggini et al., 2007) and less so with factor1 and factor2 of MetS risk factors (Kristinansson et al., 2012).

\section{Group 3: Pleiotropic genes for adiposity/obesity, lipids and inflammation}

- The SLC39A8 protein is found in the plasma membrane and mitochondria, and functions in the cellular transport of zinc at the onset of inflammation. SLC39A8 is a negative regulator of $N F-\kappa B$ and functions to negatively regulate proinflammatory responses through zincmediated down-modulation of IKB kinase (IKK) activity (Liu et al., 2013). SLC39A8 and SLC39A14 are regulated by IL-6 dependent signaling in the liver (Liuzzi et al., 2005). In addition, rs230487, which is closer to NFKB1 than SLC39A8 was associated with tissue Plasminogen activator (Yang et al., 2007). Liu et al. (2013) proposed that SLC39A8 and SLC39A14 are important zinc transporters that channel zinc in a

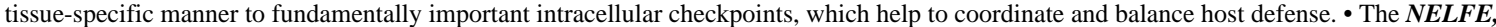
SKIV2L and STK19 position in the class III region of the major histocompatibility complex of chromosome 6 . The three genes are likely involved in transcription regulation and have been found to be associated with Macular Degeneration and Lupus Erythematosus, and rs2072633, an intron of $C F B$ - complement factor B, (but only 286 bps from NELFE gene) (International, 2007) being associated with Multiple Sclerosis. The association of $\boldsymbol{P D X D C 1}$ with ADIP may indicate that its pleiotropic effect could have protective contributions for inflammation and MetS. Based on the ENCODE information the rs4985155 is located in a transcription factor binding site and corresponds to a DNase peak (based on HaploReg (Ernst et al., 2011) and regulomeDB (Boyle et al., 2012) software). The rs4500751, (chr16:15140211) mapped at NTAN1 about $10.7 \mathrm{~K}$ bps from our PDXDC1 meta-SNP, associated with absolute plasma levels and proportions of the phospholipid species with important roles in cell survival and inflammation (Demirkan et al., 2012). Other SNPs associated with blood metabolite concentration (Suhre et al., 2011), and with phospholipids levels in plasma (Lemaitre et al., 2011). 
- The $\boldsymbol{M C 4 R}$ is a member of melanocortin family. The melanocortins are involved in pigmentation, energy homeostasis, inflammation, immunomodulation, steroidogenesis and temperature control. Stäubert et al. (2007) found a strong correlation between positional conservation and the functional relevance of missense, nonsense, and frame-shifting mutations of $M C 4 R$ affecting 60 amino acid positions. The mostly heterozygous (dominant) occurring MC4R mutations are implicated in 1-6\% of early-onset or severe adult obesity cases. Some of the GWAS findings indicated that MC4R was associated with BMI (Speliotes et al., 2010; Willer et al., 2009), obesity (Meyre et al., 2009), body height (Lango et al., 2010), with body weight (Thorleifsson et al., 2009), WAIST (Chambers et al., 2008), and with HDLC (Teslovich et al., 2010). 